\title{
Geology, Hydrology, Chemistry, and Microbiology of the In Situ Bioremediation Demonstration Site
}

\author{
D. R. Newcomer \\ L. A. Doremus \\ S. H. Hall \\ M. J. Truex \\ V. R. Vermeul \\ R. E. Engelman
}

March 1995

Prepared for

the U.S. Department of Energy

under Contract DE-AC06-76RLO 1.830

Pacific Northwest Laboratory

Richland, Washington 99352 


\section{DISCLAIMER}

This report was prepared as an account of work sponsored by an agency of the United States Government. Neither the United States Government nor any agency thereof, nor any of their employees, make any warranty, express or implied, or assumes any legal liability or responsibility for the accuracy, completeness, or usefulness of any information, apparatus, product, or process disclosed, or represents that its use would not infringe privately owned rights. Reference herein to any specific commercial product, process, or service by trade name, trademark, manufacturer, or otherwise does not necessarily constitute or imply its endorsement, recommendation, or favoring by the United States Government or any agency thereof. The views and opinions of authors expressed herein do not necessarily state or reflect those of the United States Government or any agency thereof. 


\section{DISCLAIMER}

Portions of this document may be illegible in electronic image products. Images are produced from the best available original document. 


\section{Summary}

This report summarizes characterization information on the geology, hydrology, microbiology, contaminant distribution, and ground-water chemistry to support demonstration of in situ bioremediation at the U.S. Department of Energy's (DOE's) Hanford Site. The purpose of this information is to provide baseline conditions, including a conceptual model of the aquifer being utilized for in situ bioremediation. Data were collected from sampling and other characterization activities associated with three wells drilled in the upper part of the suprabasalt aquifer.

The upper $18 \mathrm{~m}$ ( $60 \mathrm{ft}$ ) of the aquifer formation is composed primarily of gravels and sands of the Ringold Formation. These sediments exhibit variable (poor to strong) consolidation resulting from secondary alteration processes including cementation, compaction, and chemical alteration. The formation also showed variable neutron-porosity and bulk-density log responses that correlate with various degrees of consolidation.

The degree of consolidation of the sediments is the most significant influence on the variation of formation hydraulic properties with depth. Based on geologic and borehole geophysical data, 'two distinct porous zones, characterized by poor to moderate consolidation, lie at depths of approximately 75 to $78 \mathrm{~m}$ and 88 to $91 \mathrm{~m}$ ( 247 to $256 \mathrm{ft}$ and 288 to $298 \mathrm{ft}$ ). In contrast, highly consolidated (cemented) zones, occurring at depths of 84 to $87 \mathrm{~m}$ ( 277 to $285 \mathrm{ft}$ ) and below $91 \mathrm{~m}$ ( $300 \mathrm{ft}$ ), have low porosity. The highest values of horizontal hydraulic conductivity were indicated from hydraulic testing intervals at depths of 75 to $79 \mathrm{~m}$ and 89 to $91 \mathrm{~m}$ ( 247 to $258 \mathrm{ft}$ and 293 to $298 \mathrm{ft}$ ), which correspond approximately to the two distinct porous zones. Horizontal hydraulic conductivity was about an order of magnitude lower over a test interval of 83 to $85 \mathrm{~m}$ ( 273 to $278 \mathrm{ft}$ ), which corresponds approximately to the upper low-porosity zone (i.e., 84 to $87 \mathrm{~m}$ [277 to $285 \mathrm{ft}$ )).

Results of point-dilution tracer tests, conducted in the upper $9 \mathrm{~m}(30 \mathrm{ft})$ of the aquifer, showed that most ground-water flow occurs in the upper part of this zone (i.e., a depth of 75 to $78 \mathrm{~m}$ [247 to $256 \mathrm{ft}]$ ), which is consistent with hydraulic test results and geologic and geophysical data. Other tracer test results indicate that natural ground-water flow velocity is equal to or less than about $0.03 \mathrm{~m} / \mathrm{d}$ $(0.1 \mathrm{ft} / \mathrm{d})$. Laboratory hydraulic conductivity measurements, which represent the local distribution of vertical hydraulic conductivity, varied up to three orders of magnitude.

Based on concentration data from both the vadose and saturated zone, it is suggested that most, if not all, of the carbon tetrachloride detected is representative of the aqueous phase. Concentrations of carbon tetrachloride, associated with a contaminant plume in the 200-West Area, ranged from approximately 500 to $3800 \mu \mathrm{g} / \mathrm{L}$ in the aqueous phase and from approximately 10 to $290 \mu \mathrm{g} / \mathrm{L}$ in the solid phase at the demonstration site. Carbon tetrachloride gas was detected in the vadose zone, suggesting volatilization and subsequent upward migration from the saturated zone.

Ground-water chemistry parameter results and a $2 / 3$ ratio of ferric iron to total iron in sediment indicate oxidizing conditions. The results also indicate that nitrate is by far the most dominant chemical constituent present, ranging between 220 and $350 \mathrm{mg} / \mathrm{L}$. 
Microbiological analyses indicate that within and just above the aquifer, plate counts of aerobic heterotrophs ranged from $<100$ to $1.44 \times 10^{6}$ colony-forming units/g of soil and the most probable number of denitrifying bacteria ranged from $<100$ to $2.1 \times 10^{6}$ colony-forming units/g of soil.

Throughout this report, the figures and tables may use metric or english measurements exclusively. Below is a conversion table to assist the reader.

\begin{tabular}{|c|c|c|}
\hline Multiply & By & To Obtain \\
\hline $\mathrm{cm}$ & 0.394 & in. \\
\hline $\mathrm{ft}$ & 0.305 & $\mathrm{~m}$ \\
\hline $\mathrm{ft}^{2}$ & 0.093 & $\mathrm{~m}^{2}$ \\
\hline gal & 3.785 & $\mathrm{~L}$ \\
\hline $\mathrm{gm}$ & 0.035 & $\mathrm{Oz}$ \\
\hline in. & 2.54 & $\mathrm{~cm}$ \\
\hline $\mathrm{km}$ & 0.621 & mi \\
\hline $\mathrm{km}^{2}$ & 0.386 & $\mathrm{mi}^{2}$ \\
\hline $\mathrm{L}$ & 0.0264 & gal \\
\hline $\mathrm{m}$ & 3.28 & $\mathrm{ft}$ \\
\hline $\mathrm{m}^{2}$ & 10.76 & $\mathrm{ft}^{2}$ \\
\hline $\mathrm{mi}$ & 1.61 & $\mathrm{~km}$ \\
\hline $\mathrm{mi}^{2}$ & 2.59 & $\mathrm{~km}^{2}$ \\
\hline $\mathrm{oz}$ & 28.349 & gm \\
\hline
\end{tabular}




\section{Contents}

Summary $\ldots \ldots \ldots \ldots \ldots \ldots \ldots \ldots \ldots \ldots \ldots \ldots \ldots \ldots \ldots \ldots$ iii

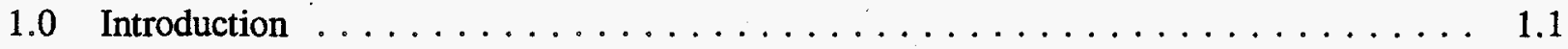

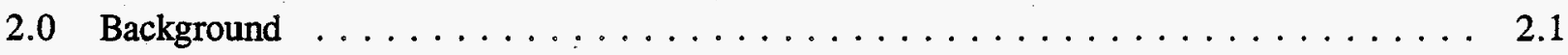

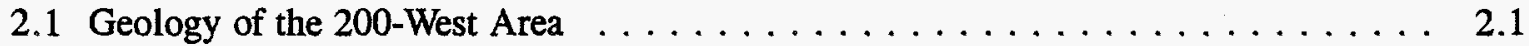

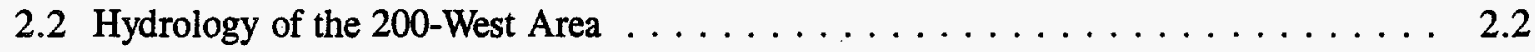

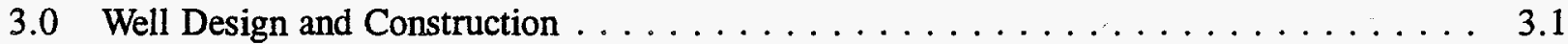

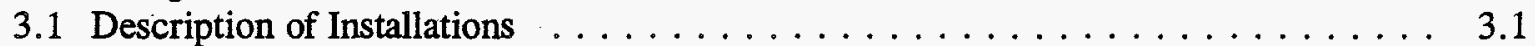

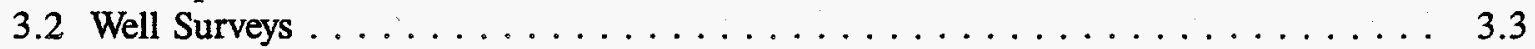

4.0 Geologic Characterization $\ldots \ldots \ldots \ldots \ldots \ldots \ldots \ldots \ldots \ldots \ldots \ldots \ldots$

4.1 Sediment Physical Properties $\ldots \ldots \ldots \ldots \ldots \ldots \ldots \ldots \ldots \ldots \ldots$

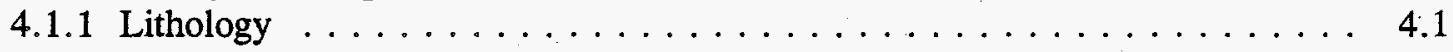

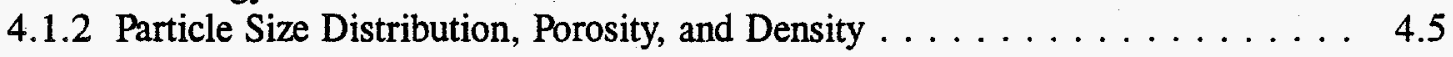

4.1 .3 Mineralogy $\ldots \ldots \ldots \ldots \ldots \ldots \ldots \ldots \ldots \ldots \ldots \ldots \ldots$

4.1.4 Laboratory-Measured Hydraulic Conductivity $\ldots \ldots \ldots \ldots \ldots \ldots \ldots$

4.2 Sediment Chemistry $\ldots \ldots \ldots \ldots \ldots \ldots \ldots \ldots \ldots \ldots \ldots \ldots$

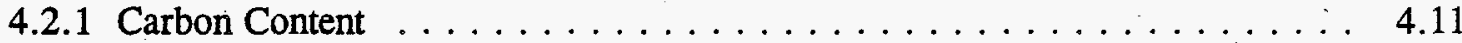

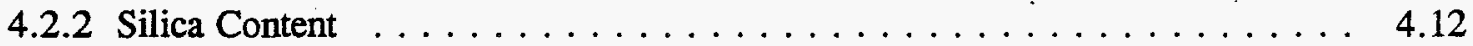

4.2 .3 Iron Content $\ldots \ldots \ldots \ldots \ldots \ldots \ldots \ldots \ldots \ldots \ldots \ldots \ldots \ldots .12$

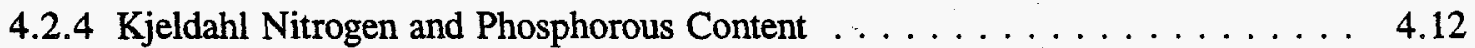

4.2 .5 Discussion . . . . . . . . . . . . . . . . . . . . . 4.15

4.3 Geophysical Logging $\ldots \ldots \ldots \ldots \ldots \ldots \ldots \ldots \ldots \ldots \ldots \ldots \ldots$

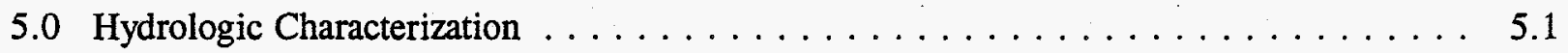

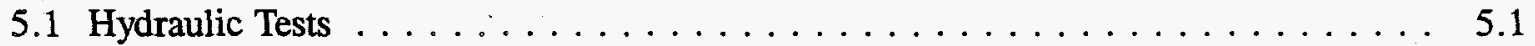

5.1 .1 Well Development $\ldots \ldots \ldots \ldots \ldots \ldots \ldots \ldots \ldots \ldots \ldots \ldots$

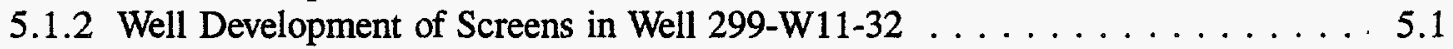

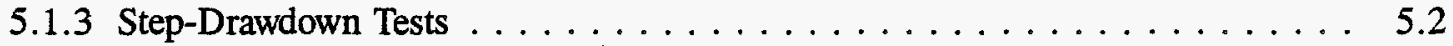

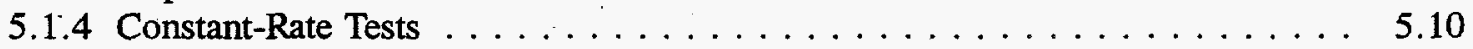

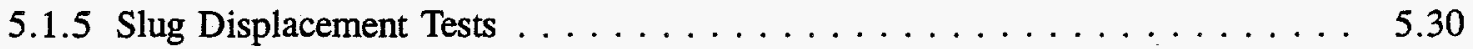

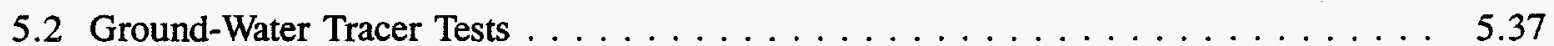

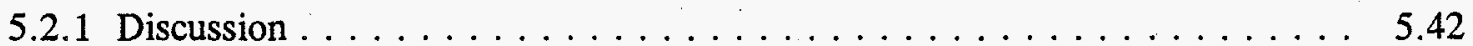

5.3 Water-Level Monitoring . . . . . . . . . . . . . . . 5.43 
6.0 Contaminant Distribution $\ldots \ldots \ldots \ldots \ldots \ldots \ldots \ldots \ldots \ldots \ldots \ldots \ldots \ldots \ldots \ldots \ldots \ldots .1$

6.1 Gas Phase Contaminant Distribution $\ldots \ldots \ldots \ldots \ldots \ldots \ldots \ldots \ldots . \ldots \ldots .1$

6.2 Solid Phase Contaminant Distribution $\ldots \ldots \ldots \ldots \ldots \ldots \ldots \ldots \ldots .6 .2$

6.3 Aqueous Phase Contaminant Distribution $\ldots \ldots \ldots \ldots \ldots \ldots \ldots \ldots .2$

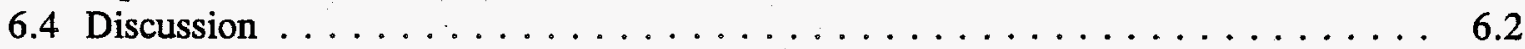

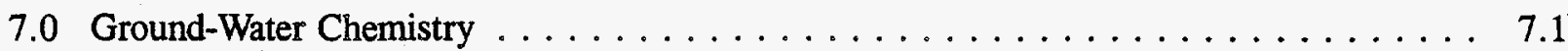

7.1 Water Chemistry Parameters $\ldots \ldots \ldots \ldots \ldots \ldots \ldots \ldots \ldots \ldots \ldots . \ldots \ldots \ldots . \ldots \ldots \ldots$

7.2 Anions and Cations $\ldots \ldots \ldots \ldots \ldots \ldots \ldots \ldots \ldots \ldots \ldots \ldots \ldots \ldots \ldots \ldots \ldots \ldots \ldots .2$

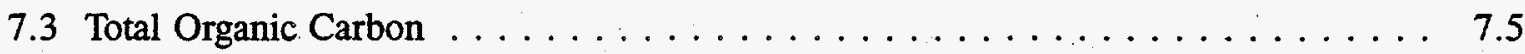

8.0 Microbiological Characterization $\ldots \ldots \ldots \ldots \ldots \ldots \ldots \ldots \ldots \ldots .1$

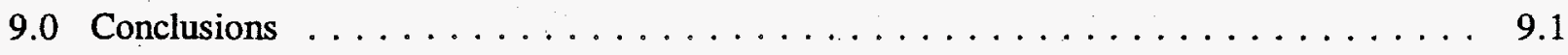

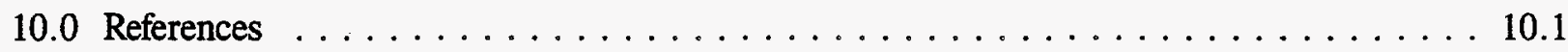

\section{Figures}

1.1 Location of the In Situ Bioremediation Demonstration Well Site . . . . . . . . . 1.2

3.1 The Depths of the Screened Intervals and the Well Configurations for the First Three Wells Installed $\ldots \ldots \ldots \ldots \ldots \ldots \ldots \ldots \ldots .2$

3.2 Depth Profiles of Wells a) 299-W11-29, b) 299-W11-30, and c) 299-W11-32 $\ldots \ldots \quad 3.5$

3.3 Plan View of Wells at the Surface and at Total Depth $\ldots \ldots \ldots \ldots \ldots \ldots . \ldots$

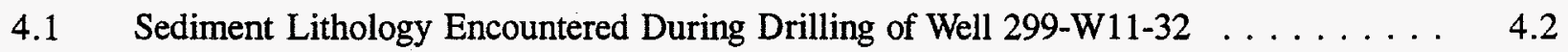

4.2 Non-Gravel Sediment Size Distribution as a Function of Depth for Samples Collected from Well $299-\mathrm{W} 11-32 \ldots \ldots \ldots \ldots \ldots \ldots \ldots \ldots . .6 \ldots \ldots$

4.3 Sediment Size Distribution as a Function of Depth for Samples Collected from All Three Wells . . . . . . . . . . . . . . . . . . . . . 4.8

4.4 Clay-Sized Fraction Mineralogy as a Function of Depth for Sediment Samples Collected from Well 299-W11-32

4.5 Total Carbon, Carbonate Carbon, and Organic Carbon Contents as a

Function of Depth for Sediment Samples Taken from Well 299-W11-30 
4.6 Total Carbon, Carbonate Carbon, and Organic Carbon Contents as a

Function of Depth for Sediment Samples Taken from Well 299-W11-32 . . . . . . . . 4.14

4.7 Iron Content as a Function of Depth for Sediment Samples Collected

from Well $299-W 11-32 \ldots \ldots \ldots \ldots \ldots \ldots \ldots \ldots \ldots . \ldots \ldots \ldots$

$4.8 \quad$ Neutron Porosity $\log$ of Well $299-W 11-32 \ldots \ldots \ldots \ldots \ldots \ldots$

$4.9 \quad$ Bulk Density $\log$ of Well $299-W 11-32 \ldots \ldots \ldots \ldots \ldots \ldots \ldots \ldots \ldots \ldots$

5.1 Test Configuration for the Upper Screened Interval of Well 299-W11-32 $\ldots \ldots \ldots$

$5.2 \quad$ Test Configuration for the Middle Screened Interval of Well 299-W11-32 $\ldots \ldots \ldots$

$5.3 \quad$ Test Configuration for the Bottom Screened Interval of Well 299-W11-32 $\ldots \ldots \ldots$

$5.4 \quad$ Step Drawdown Plot of the Upper Screened Interval of Well 299-W11-32 $\ldots \ldots \ldots$. . 5.7

5.5 Step Drawdown Plot of the Bottom Screened Interval of Well 299-W11-32 $\ldots \ldots \ldots$

$5.6 \quad$ Step Drawdown Plot of Well $299-W 11-29 \ldots \ldots \ldots \ldots \ldots \ldots$

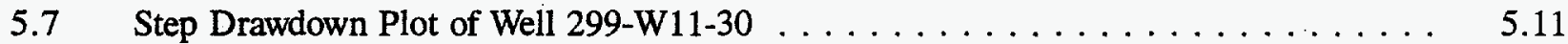

5.8 Water-Level and Barometric Pressure Data for the Upper Screened

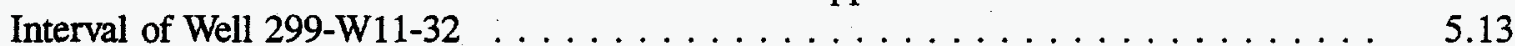

5.9 Type-Curve Drawdown Data Analysis for Well $299-W 11-29 \ldots \ldots \ldots \ldots$

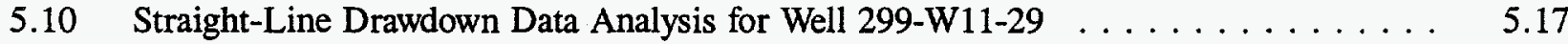

5.11 Type-Curve Recovery Data Analysis for Well $299-W 11-29 \ldots \ldots \ldots \ldots \ldots$

5.12 Type-Curve Recovery Data Analysis for Well $299-W 11-29 \ldots \ldots \ldots \ldots \ldots$

5.13 Type-Curve Recovery Data Analysis for Well $299-W 11-30 \ldots \ldots \ldots \ldots \ldots$

5.14 Straight-Line Recovery Data Analysis for Well $299-W 11-29 \ldots \ldots \ldots \ldots \ldots \ldots$

5.15 Straight-Line Recovery Data Analysis for Well $299-W 11-30 \ldots \ldots \ldots \ldots .23$

5.16 Diagnostic Plot of Drawdown and Drawdown Derivation for the

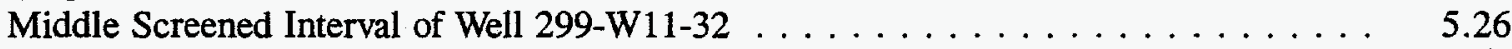

5.17 Straight-Line Drawdown Data Analysis for the Middle Screened

Interval of Well $299-W 11-32 \ldots \ldots \ldots \ldots \ldots \ldots$ 
5.18 Diagnostic Plot of Drawdown and Drawdown Derivation for the

Bottom Screened Interval of Well 299-W11-32 . . . . . . . . . . . . . . .

5.19 Straight-Line Drawdown Data Analysis for the Bottom Screened

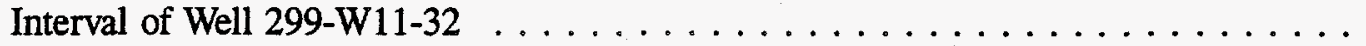

5.20 Slug Test Configuration for a) Middle Screened Interval and

b) Bottom Screened Interval of Well 299-W11-32 . . . . . . . . . . . . . 5.31

5.21 Bouwer and Rice Analysis for the Middle Screened Interval of

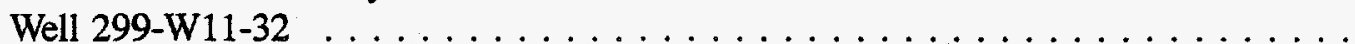

5.22 Bouwer and Rice Analysis for the Bottom Screened Interval of

Well 299-W11-32

5.23 Slug Test Type-Curve Analysis for the Middle Screened Interval of

Well 299-W11-32 . . . . . . . . . . . . . . . . . . . . . . . . . . . .

5.24 Slug Test Type-Curve Analysis for the Bottom Screened Interval of

5.25 Point-Dilution Test Results of Well 299-W11-29 for January $1994 \ldots \ldots \ldots \ldots$

5.26 Point-Dilution Test Results of Well $299-$ W11-30 for January $1994 \ldots \ldots \ldots$. . . . . 5.40

5.27 Relative Horizontal Ground-Water Flow Velocity Through the Well Bore

as a Function of Depth for Wells 299-W11-29 and 299-W11-30 . . . . . . . . . .

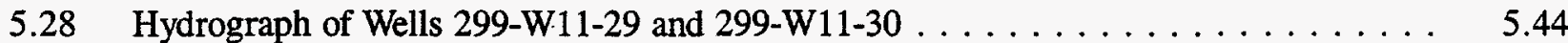

5.29 Water-Table Map for August $1993 \ldots \ldots \ldots \ldots \ldots \ldots \ldots \ldots \ldots$

6.1 Volatile Organic Compound Concentrations in Sediment Samples

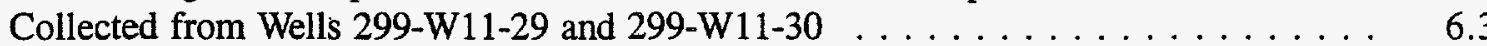

6.2 Volatile Organic Compound Concentrations in Sediment Samples

Collected from Well $299-W 11-32 \ldots \ldots \ldots \ldots \ldots$. . . . . . . . . . . . . . . . .

6.3 Volatile Organic Compound Concentrations in Ground Water from

Well 299-W11-29

6.4 Volatile Organic Compound Concentrations in Ground-Water Samples

Collected During Drilling Advancement of Well 299-W11-32 . . . . . . . . . . .

6.5 Volatile Organic Compound Concentrations in Ground-Water Samples

Collected from Well 299-W11-32 After Completion . . . . . . . . . . . . . . . 
7.1 Anions Analysis Results for Well $299-W 11-30 \ldots \ldots \ldots \ldots \ldots$

7.2 Anions Analysis Results for the Three Screened Intervals of Well 299-W11-32 _ . . 7.4

$7.3 \quad$ Metals Analysis Results for Well $299-W 11-30 \ldots \ldots \ldots \ldots \ldots$

7.4 Metals Analysis Results for the Three Screened Intervals of Well 299-W11-32 . . . . 7.7

7.5 Metals Analysis Results for Samples Collected at a Depth of $82 \mathrm{~m}$ (268 Ft) During

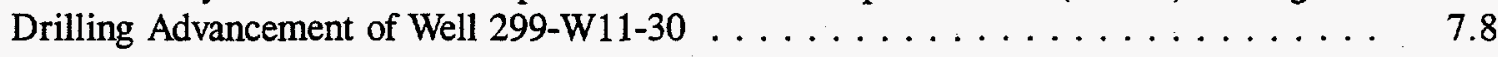

7.6 Metals Analysis Results for Samples Collected During Drilling Advancement

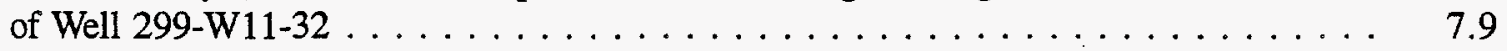

9.1 Summary of Site Characterization Information for the Upper Portion of the Unconfined Aquifer . . . . . . . . . . . . . . . . . . . 9.3

\section{Tables}

3.1 Horizontal and Vertical Well Survey Data $\ldots \ldots \ldots \ldots \ldots . \ldots \ldots$

3.2 Downhole Vertical Deviation Survey of Well 299-W11-29 Corresponding

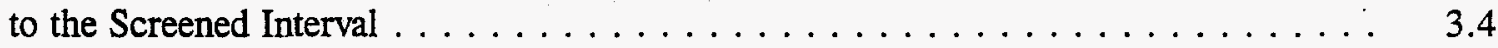

3.3 Downhole Vertical Deviation Survey of Well 299-W11-30 Corresponding

to the Screened Interval . . . . . . . . . . . . . . . . . . . . . . . . . 3.4

3.4 Downhole Vertical Deviation Survey of Well 299-W11-32 Corresponding to the Screened Intervals $\ldots \ldots \ldots \ldots \ldots \ldots \ldots \ldots \ldots \ldots$

4.1 Sediment Size Distribution Using the Wet Sieve Method for Clay-, Silt-, and Sand-Size Categories $\ldots \ldots \ldots \ldots \ldots \ldots \ldots \ldots \ldots$

4.2 Particle Density, Bulk Density, and Porosity for Sediment Samples from the Saturated Zone of Well 299-W11-32 . . . . . . . . . . . . . . . . .

4.3 Hydraulic Conductivity $(\mathrm{K})$ Values Measured with Falling Head Permeameter on Samples from Well $299-W 11-32 \ldots \ldots \ldots \ldots \ldots \ldots \ldots$

4.4 Amorphous Silica Content of Middle Ringold Sediments Collected from Well 299-W11-32 
5.1 Sustainable Maximum Flow Rates $\left(\mathrm{Q}_{\max }\right)$ Determined from the Step

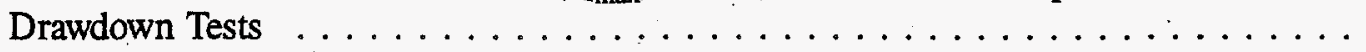

5.2 Barometric Efficiency Results for the Monitoring Well Locations . . . . . . . . . 5.14

5.3 Hydraulic Properties Estimated Using Straight-Line and Type-Curve Matching Techniques $\ldots \ldots \ldots \ldots \ldots \ldots \ldots \ldots \ldots \ldots \ldots \ldots \ldots \ldots \ldots \ldots \ldots .24$

5.4 Results of Slug Displacement Tests Conducted in Well 299-W11-32 . . . . . . 5.32

6.1 Soil Gas Analysis Results for Samples Taken with the Boresampler from

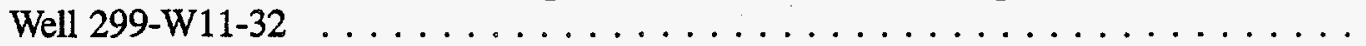

6.2 Volatile Organic Compound Concentrations in Ground Water Collected

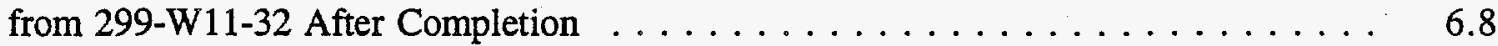

$7.1 \quad$ Hydrochemical Parameters Measured in Well $299-W 11-32 \ldots \ldots \ldots \ldots \ldots .1$

7.2 Average Results of Major Hydrochemical Ground-Water Constituents

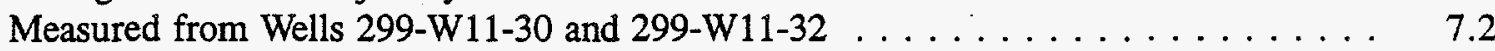

8.1 Results of CFU Data for Aerobic Heterotrophs from Various Sample Depths . . . . . 8.1

8.2 Results of CFU Data for Denitrifying Bacteria from Various Sample Depths . . . . 8.2 


\subsection{Introduction}

The U.S. Department of Energy's (DOE's) Office of Technology Development has initiated the Volatile Organic Compounds-Arid Integrated Demonstration (VOC-Arid ID) program to develop, demonstrate, and deploy new technologies for restoring contaminated soils and ground water at arid DOE sites. One of these technologies is in situ bioremediation, which focuses on treatment of carbon tetrachloride and nitrate in ground water at DOE's Hanford Site in southeastern Washington. The in situ bioremediation method being investigated involves anaerobic destruction of the contaminants by stimulating the growth of indigenous (native) microorganisms in the aquifer. Stimulation of the microorganisms, and consequent contaminant destruction, is controlled by deploying a nutrient addition strategy in an artificially induced ground-water flow regime. The purpose of in situ bioremediation is to design and implement a method to stimulate native microorganisms to biodegrade carbon tetrachloride $\left(\mathrm{CCl}_{4}\right)$ and nitrate in ground water.

Under the direction of Westinghouse Hanford Company (WHC), Pacific Northwest Laboratory (PNL), in collaboration with university support, is developing and demonstrating the in situ bioremediation technology. The components to support this technology include laboratory studies, computer simulations, a well network installation for deploying and monitoring the field demonstration, and characterization of the subsurface. The objective of this report is to provide baseline characterization information and to develop a conceptual model of the aquifer. Characterization data include the geology, hydrology, microbiology, contaminant distribution, and ground-water chemistry of the demonstration site. These data were collected from sampling and other characterization activities associated with three wells drilled in the upper part of the aquifer.

The in situ bioremediation demonstration field site is located between 241-T Tank Farm and 221-T Plant in the 200-West Area of the Hanford Site, as shown in Figure 1.1. The field site is located approximately $1.2 \mathrm{~km}$ to $1.5 \mathrm{~km}(0.7 \mathrm{mi}$ to $0.9 \mathrm{mi})$ northeast of the Plutonium Finishing Plant, the location where $\mathrm{CCl}_{4}$ was disposed of to the ground during past Hanford production operations.

Specifically, this report includes brief descriptions of the geology and hydrology in the 200-West Area (Section 2.0), the well installations at the field demonstration site (Section 3.0), geologic characterization (Section 4.0), hydrologic characterization (Section 5.0), contaminant distribution (Section 6.0), ground-water chemistry (Section 7.0), and microbiologic characterization (Section 8.0). These sections are followed by conclusions interpreted from the characterization data (Section 9.0). 


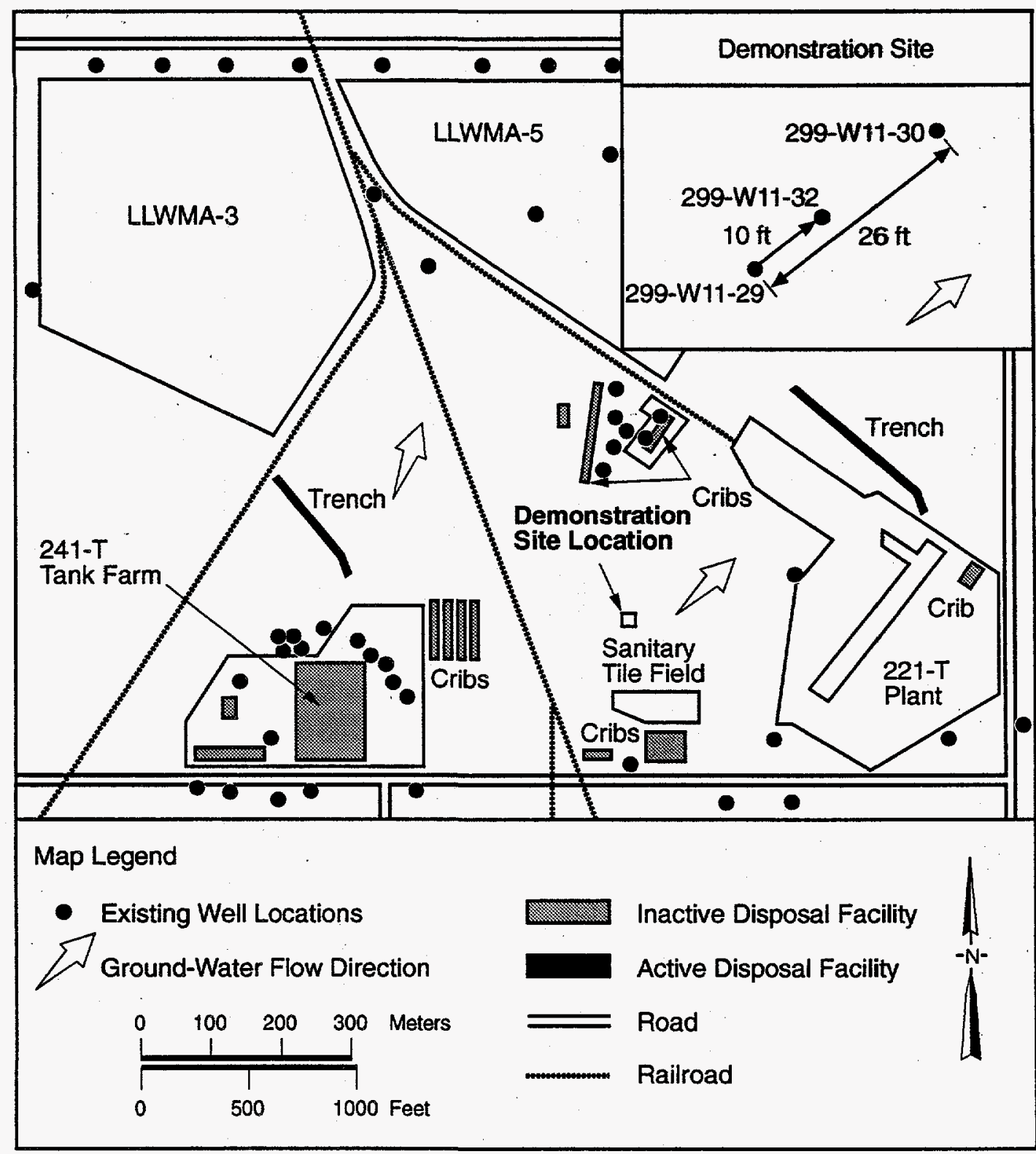

$\$ 9407011.10$

Figure 1.1. Location of the In Situ Bioremediation Demonstration Well Site 


\subsection{Background}

This section briefly describes the geology and hydrology of the 200-West Area. The purpose is to provide a general overview focusing on the 200-West Area. More complete details of the geology and hydrology of this area can be found in recent documents by DOE (1988), Last et al. (1989), Lindsey et al. (1991), and Connelly et al. (1992).

\subsection{Geology of the 200-West Area}

The 200-West Area consists of sediments deposited by the ancestral Columbia River and glaciofluvial deposits from the cataclysmic floods during melting of the Pleistocene glaciers. These sediments rest on the Elephant Mountain member of the Columbia River basalt group, whose surface forms a syncline with a northwest-southeast trending axis. The top of the basalt is approximately $150 \mathrm{~m}$ $(500 \mathrm{ft})$ below the ground surface, which is the base of the suprabasalt sediments. Sediments of the Ringold Formation, deposited on the basalt surface, dip gently to the south and southwest beneath the 200 -West Area. Between the Ringold Formation and the ground surface lies a 30-m (100-ft)-thick sequence of glaciofluvial deposits known informally as the Hanford formation (Lindsey et al. 1991; Connelly et al. 1992).

The Ringold Formation is made up of unconsolidated and semi-consolidated fluvial and lacustrine

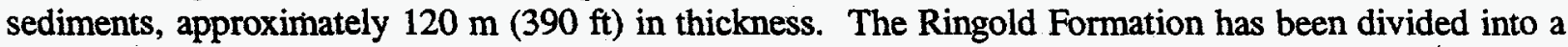
number of units and lenses according to the depositional environment of the sediments. The lowermost unit, classified as Gravel Unit A by Lindsey et al. (1991), consists of gravels and interbedded sand and silt lenses. The lower mud sequence overlies the Gravel Unit A (Connelly et al. 1992). The overlying fluvial Gravel Unit E, composed of muddy sandy gravels interbedded with sand and muddy sand lenses

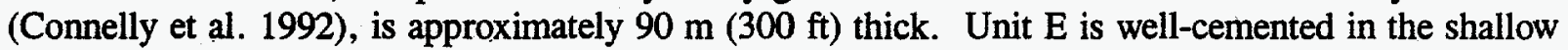
saturated zone and rests conformably on the lower mud sequence. Overlying Unit $E$, the upper

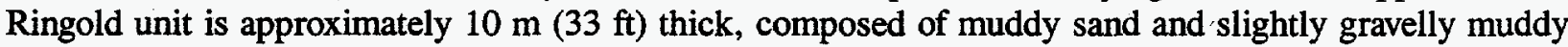
sand.

Between the deposits of the Ringold Formation and the overlying Hanford formation are two relatively thin stratigraphic units. The Plio-Pleistocene Unit is identified by well-cemented calcium carbonate enriched sediments in most of the 200-West Area. A distinct caliche cemented layer, less than a meter in thickness, is present at the base of the unit. The overlying early "Palouse" soil is primarily a loess composed of fine-grained sand and silt.

The overlying Hanford formation consists of Pleistocene cataclysmic flood deposits from glacial Lake Missoula. In the northern part of the 200-West Area, the Hanford formation is composed of unconsolidated, gravel-dominated sediments deposited by a series of floods. In the central and southern parts of the 200 -West Area, the Hanford formation is characterized by both sand-dominated, intermediate-energy flood-water deposits and fine-grained slackwater deposits. The intermediate sized sand and slightly gravelly sands deposited in the Hanford formation beneath the demonstration site are likely to have been transported by floodwaters moving at a rate between those two extremes. At the demonstration site, the Hanford formation is approximately $30 \mathrm{~m}(100 \mathrm{ft})$ thick. Overlying the

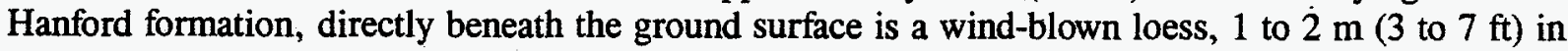
thickness. 


\subsection{Hydrology of the 200-West Area}

Both confined and unconfined aquifers are present beneath the 200-West Area. The confined aquifers lie primarily within the Columbia River basalts. The unconfined aquifer beneath the 200 -West Area lies within the Ringold Formation (Gephart et al. 1979).

The unconfined aquifer is bounded below by either the basalt surface or the relatively impervious clays and silts of the lower mud unit of the Ringold Formation. Laterally, the unconfined aquifer is bounded by surrounding basalt ridges, primarily to the north, west, and south, and hydrologically by the Columbia River to the north and east.

The unconfined aquifer beneath the 200 -West Area is recharged by the Cold Creek drainage to the west. The aquifer is also recharged by waste water disposal, which has caused ground-water mounding in the 200-West Area (Dresel et al. 1993). Ground water generally flows east across the 200-West Area and discharges north and east to the Columbia River.

The saturated thickness of the unconfined aquifer in the 200-West Area is approximately $220 \mathrm{ft}$ (Connelly et al. 1992). The unconfined aquifer pinches out along the flanks of the surrounding basalt ridges as they rise above the elevation of the water table. The depth to the water table in the 200 -West Area ranges between about 60 and $84 \mathrm{~m}$ (200 and $275 \mathrm{ft}$ ) below land surface. 


\subsection{Well Design and Construction}

Three wells, 299-W11-29, 299-W11-30, and 299-W11-32, were installed at the in situ bioremediation field site. The first two wells (299-W11-29 and 299-W11-30) were drilled in FY91 and FY92 and were primarily installed to provide preliminary characterization data. Based on these data; a third well was designed and installed in FY93 and FY94, primarily for the purpose of deploying the bioremediation technology. In addition, this well was used for more intense characterization to better define the spatial variability of the geology, hydrology, microbiology, and contaminant distribution. Based on these data, additional wells planned for FY94 were designed as part of the final well network, which will be documented in an integrated test plan. As a consequence of the design, the three installed wells will ultimately be used to deploy, control, and monitor the demonstration as a part of the final well network.

\subsection{Description of Installations}

Three wells penetrate the upper part of the unconfined aquifer at the in situ bioremediation site. The first two drilled wells were similarly constructed with single screens completed across the water table, which lies at a depth of approximately $75.3 \mathrm{~m}(247 \mathrm{ft})$ below land surface. The third drilled well was constructed with three separate screens, the top screen completed across the water table and the lower two screens completed below the water table. Figure 3.1 shows the depths of the screened intervals relative to each other.

The first two wells installed, 299-W11-29 and 299-W11-30, were drilled to depths of $85.3 \mathrm{~m}$ $(280 \mathrm{ft})$ and $86.6 \mathrm{~m}(284 \mathrm{ft})$, respectively, below land surface. The well construction diagram is shown

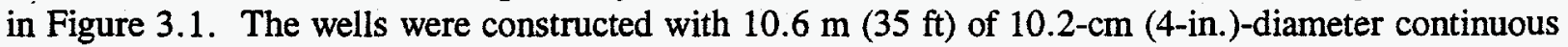
wire-wrap, 10-slot (0.010 in.) stainless steel screen. The screens were set from approximately $74.4 \mathrm{~m}$ $(244 \mathrm{ft})$ to approximately $85.0 \mathrm{~m} \mathrm{(279} \mathrm{ft)} \mathrm{below} \mathrm{land} \mathrm{surface} \mathrm{with} \mathrm{10.2-cm} \mathrm{(4-in.)} \mathrm{diameter} \mathrm{stainless}$ steel casing extending from $74.4 \mathrm{~m}(244 \mathrm{ft})$ to the surface. Artificial filter packs were installed in the annular space adjacent to the screens. The depth to the water table during well installation was approximately $75 \mathrm{~m}(247 \mathrm{ft})$ below land surface.

The third well, 299-W11-32, was drilled to $94.5 \mathrm{~m}$ ( $310 \mathrm{ft}$ ) below land surface. This well was constructed of 20.3-cm (8-in.)-diameter stainless steel casing and screen. Three separate screened intervals were constructed with continuous wire-wrap, 10-slot (0.010 in.) screen at depths of 74.1 to $78.6 \mathrm{~m}$ ( 243 to $258 \mathrm{ft}$ ), 83.2 to $84.7 \mathrm{~m}$ ( 273 to $278 \mathrm{ft}$ ), and 89.3 to $90.8 \mathrm{~m}$ ( 293 to $298 \mathrm{ft}$ ) below land surface. These screened intervals were separated by $20.3-\mathrm{cm}(8$-in.)-diameter blank casing. Bentonite was placed in the annular space around the blank casing to hydraulically isolate each zone. Artificial filter packs were installed in the annular space adjacent to the screens. A $20.3-\mathrm{cm}$ (8-in.)-diameter casing was also placed below the bottom screen between a depth of $90.8 \mathrm{~m}(298 \mathrm{ft})$ and $94 \mathrm{~m}(308 \mathrm{ft})$ and above the top screen to the surface. A diagram of well construction is shown in Figure 3.1. 


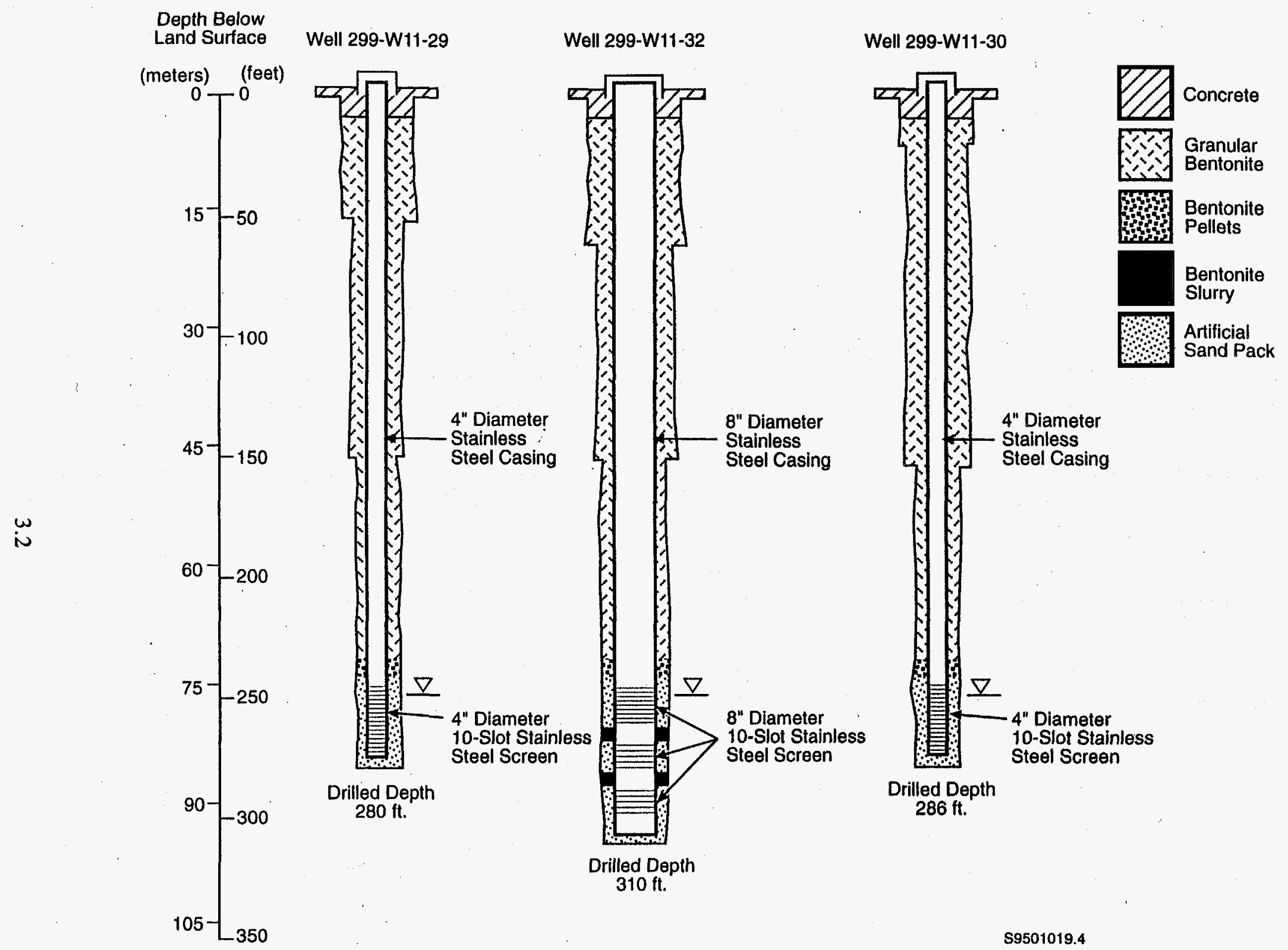

Figure 3.1. The Depths of the Screened Intervals and the Well Configurations for the First Three Wells Installed 


\subsection{Well Surveys}

After completion, wells 299-W11-29 and 299-W11-30 were surveyed by ICF Kaiser Hanford (ICF KH) to determine the horizontal coordinates and the elevation of the top of casing and concrete pad above mean sea level. The horizontal survey was relative to the Hanford Plant Coordinate System (HPCS) and the Lambert coordinate system. The vertical survey was relative to the National Geodetic Vertical Datum of 1929. The survey location was stamped with an "X" on top of the north side of the well casing. Well 299-W11-32 will be surveyed for horizontal coordinates and elevation after the remaining wells have been installed.

The survey data are presented in Table 3.1. The accuracy of the horizontal survey is estimated to be $\pm 0.2 \mathrm{~m}( \pm 0.5 \mathrm{ft})$, and accuracy of the vertical elevations are estimated to be $\pm 0.01 \mathrm{~m}( \pm 0.04 \mathrm{ft})$. The ICF KH survey was conducted before well 299-W11-32 was installed. The horizontal coordinates of well 299-W11-32, which is located in a straight line between wells 299-W11-29 and 299-W11-30, were estimated from the ICF KH survey and measured distances between the wells. These estimates will be used until the survey of well 299-W11-32 is conducted. The measured distance between the center of wells $299-\mathrm{W} 11-29$ and $299-\mathrm{W} 11-32$ is $3.4 \mathrm{~m}(11.3 \mathrm{ft})$, and the measured distance between the center of wells $299-\mathrm{W} 11-30$ and $299-\mathrm{W} 11-32$ is $4.5 \mathrm{~m}(14.7 \mathrm{ft})$.

The deviation from vertical of each well was measured by Scientific Drilling International to determine the location of the well screen with respect to the entry point at the surface. These data were needed to determine the distances between corresponding well screened intervals at depth. Survey measurements were conducted every $1.5 \mathrm{~m}(5 \mathrm{ft})$ between ground surface and total depth to yield angular deviation (incremental degrees) from vertical, direction, and departure from the surface latitude/longitude coordinate location. These data were also used to correct for the vertical depth of the wells. For the purpose of this report, only survey data for depths corresponding to the well screened intervals are tabulated in Tables 3.2, 3.3, and 3.4. Depth profiles for each well and a plan view, showing the locations of the well at the surface and at total depth, are shown in Figures 3.2 and 3.3, respectively.

Table 3.1. Horizontal and Vertical Well Survey Data

\begin{tabular}{|c|c|c|c|c|}
\hline Well Number & HPCS (ft) & Lambert (m) & $\begin{array}{c}\text { Brass Plate on } \\
\text { Concrete Pad (ft }[\mathrm{m}] \\
\text { above mean sea level) }\end{array}$ & $\begin{array}{l}\text { North Side of } \\
\text { Top of Casing } \\
\text { (ft [m] above } \\
\text { mean sea level) }\end{array}$ \\
\hline 299-W11-29 & $\begin{array}{l}N: 43,930.8 \\
W: 74,483.3\end{array}$ & $\begin{array}{l}N: 136,852.0 \\
E: 567,189.4\end{array}$ & 706.17 [215.24] & $709.11[216.14]$ \\
\hline 299-W11-30 & $\begin{array}{l}\mathrm{N}: 43,953.4 \\
\mathrm{~W}: 74,470.2\end{array}$ & $\begin{array}{l}N: 136,858.9 \\
E: 567,193.4\end{array}$ & $706.03[215.20]$ & $709.04[216.12]$ \\
\hline 299-W11-32 & $\begin{array}{l}\mathrm{N}: 43,940.6 \\
\mathrm{~W}: 74,477.7\end{array}$ & $\begin{array}{l}N: 136,855.0 \\
E: 567,191.1\end{array}$ & - & - \\
\hline
\end{tabular}


Table 3.2. Downhole Vertical Deviation Survey of Well 299-W11-29 Corresponding to the Screened Interval (Depth of Screened Interval: 243 to $279 \mathrm{ft}$ )

\begin{tabular}{|c|c|c|c|c|c|}
\hline $\begin{array}{l}\text { Measured } \\
\text { Depth (ft) }\end{array}$ & $\begin{array}{l}\text { Direction } \\
\text { from Surface } \\
\text { Entry Point }\end{array}$ & $\begin{array}{c}\text { Departure (ft) } \\
\text { Latitude } \\
\mathrm{N}+/ \mathrm{S}-\end{array}$ & $\begin{array}{c}\text { Corrected } \\
\text { Longitude } \\
E+/ W-\end{array}$ & $\begin{array}{l}\text { Vertical } \\
\text { Depth } \\
\text { (ft) }\end{array}$ & $\begin{array}{l}\text { Horizontal } \\
\text { Distance } \\
\text { from Entry } \\
\text { Point (ft) }\end{array}$ \\
\hline 245.0 & $S 84^{\circ} 13^{\prime \prime} \mathrm{E}$ & -0.31 & 2.27 & 244.97 & 2.29 \\
\hline 250.0 & $S 82^{\circ} 32^{\prime \prime} \mathrm{E}$ & -0.30 & 2.35 & 249.97 & 2.37 \\
\hline 255.0 & $S 82^{\circ} 08^{\prime \prime} \mathrm{E}$ & -0.29 & 2.46 & 254.97 & 2.48 \\
\hline 260.0 & $S 82^{\circ} 13^{\prime \prime} \mathrm{E}$ & -0.27 & 2.58 & 259.97 & 2.59 \\
\hline 265.0 & $S 82^{\circ} 04^{\prime E} \mathrm{E}$ & -0.25 & 2.72 & 264.97 & 2.73 \\
\hline 270.0 & $S 80^{\circ} 51^{\prime \prime} \mathrm{E}$ & -0.23 & 2.87 & 269.97 & 2.88 \\
\hline 275.0 & $S 77^{\circ} 51^{\prime \prime} \mathrm{E}$ & -0.20 & 3.02 & 274.96 & .3 .03 \\
\hline
\end{tabular}

Table 3.3. Downhole Vertical Deviation Survey of Well 299-W11-30 Corresponding to the Screened Interval (Depth of Screened Interval: 243 to $279 \mathrm{ft}$ )

\begin{tabular}{|c|c|c|c|c|c|}
\hline $\begin{array}{l}\text { Measured } \\
\text { Depth (ft) }\end{array}$ & $\begin{array}{l}\text { Direction } \\
\text { from Surface } \\
\text { Entry Point }\end{array}$ & $\begin{array}{c}\text { Departure (ft) } \\
\text { Latitude } \\
\mathrm{N}+/ \mathrm{S}-\end{array}$ & $\begin{array}{c}\text { Corrected } \\
\text { Longitude } \\
\mathbf{E}+/ \mathrm{W}-\end{array}$ & $\begin{array}{l}\text { Vertical } \\
\text { Depth } \\
\text { (ft) }\end{array}$ & $\begin{array}{c}\text { Horizontal } \\
\text { Distance } \\
\text { from Entry } \\
\text { Point (ft) }\end{array}$ \\
\hline 245.0 & $S 47^{\circ} 55^{n} \mathrm{E}$ & -4.45 & 6.00 & 244.87 & 7.47 \\
\hline 250.0 & $S 51^{\circ} 26^{\prime \prime} \mathrm{E}$ & -4.56 & 6.13 & 249.86 & 7.64 \\
\hline 255.0 & $S 55^{\circ} 24^{\prime \prime E}$ & -4.65 & 6.25 & 254.86 & 7.79 \\
\hline 260.0 & $S 59^{\circ} 24^{\mathrm{IE}}$ & -4.73 & 6.37 & 259.86 & 7.93 \\
\hline 265.0 & $S 62^{\circ} 57^{\prime \prime} \mathrm{E}$ & -4.79 & 6.49 & 264.86 & 8.07 \\
\hline 270.0 & $S 65^{\circ} 36^{\prime \prime E}$ & -4.85 & 6.60 & 269.86 & 8.19 \\
\hline 275.0 & $S 66^{\circ} 55^{\prime \prime} \mathrm{E}$ & -4.90 & 6.71 & 274.86 & 8.31 \\
\hline 280.0 & $S 66^{\circ} 26^{\prime \prime} \mathrm{E}$ & -4.95 & 6.84 & 279.85 & 8.44 \\
\hline
\end{tabular}

Table 3.4. Downhole Vertical Deviation Survey of Well 299-W11-32 Corresponding to the Screened Intervals (Depth of Screened Intervals: 243 to $258 \mathrm{ft}, 273$ to $278 \mathrm{ft}$, and 293 to $298 \mathrm{ft}$ )

\begin{tabular}{|c|c|c|c|c|c|}
\hline $\begin{array}{l}\text { Measured } \\
\text { Depth (ft) }\end{array}$ & $\begin{array}{l}\text { Direction } \\
\text { from Surface } \\
\text { Entry Point }\end{array}$ & $\begin{array}{c}\text { Departure (ft) } \\
\text { Latitude } \\
\mathrm{N}+/ \mathrm{S}-\end{array}$ & $\begin{array}{l}\text { Corrected } \\
\text { Longitude } \\
E+/ W-\end{array}$ & $\begin{array}{l}\text { Vertical } \\
\text { Depth } \\
\text { (ft) }\end{array}$ & $\begin{array}{l}\text { Horizontal } \\
\text { Distance } \\
\text { from Entry } \\
\text { Point (ft) }\end{array}$ \\
\hline 245.0 & $\mathrm{~N} 47^{\circ} 34^{\mathrm{n}} \mathrm{W}$ & 2.41 & -2.27 & 244.94 & 3.31 \\
\hline 250.0 & $\mathrm{~N} 48^{\circ} 48^{n} \mathrm{~W}$ & 2.48 & -2.34 & 249.94 & 3.41 \\
\hline 255.0 & $\mathrm{~N} 49^{\circ} 41^{\prime \prime} \mathrm{W}$ & 2.54 & -2.41 & 254.94 & 3.50 \\
\hline 260.0 & $\mathrm{~N} 50^{\circ} 11^{\prime \prime} \mathrm{W}$ & 2.60 & -2.49 & 259.94 & 3.60 \\
\hline 270.0 & $\mathrm{~N} 48^{\circ} 41^{\prime \prime} \mathrm{W}$ & 2.73 & -2.63 & 269.94 & 3.79 \\
\hline 275.0 & $\mathrm{~N} 47^{\circ} 56^{\prime \prime} \mathrm{W}$ & 2.81 & -2.72 & 274.94 & 3.91 \\
\hline 280.0 & $\mathrm{~N} 47^{\circ} 36^{\prime \prime} \mathrm{W}$ & 2.89 & -2.81 & 279.93 & 3.97 \\
\hline 290.0 & $\mathrm{~N} 52^{\circ} 02^{\prime \prime} \mathrm{W}$ & 3.04 & -2.99 & 289.93 & 4.26 \\
\hline 295.0 & $\mathrm{~N} 54^{\circ} 14^{\prime \prime} \mathrm{W}$ & 3.11 & -3.08 & 294.93 & 4.38 \\
\hline 300.0 & $\mathrm{~N} 55^{\circ} 48^{\prime \prime} \mathrm{W}$ & 3.17 & -3.17 & 299.93 & 4.48 \\
\hline
\end{tabular}



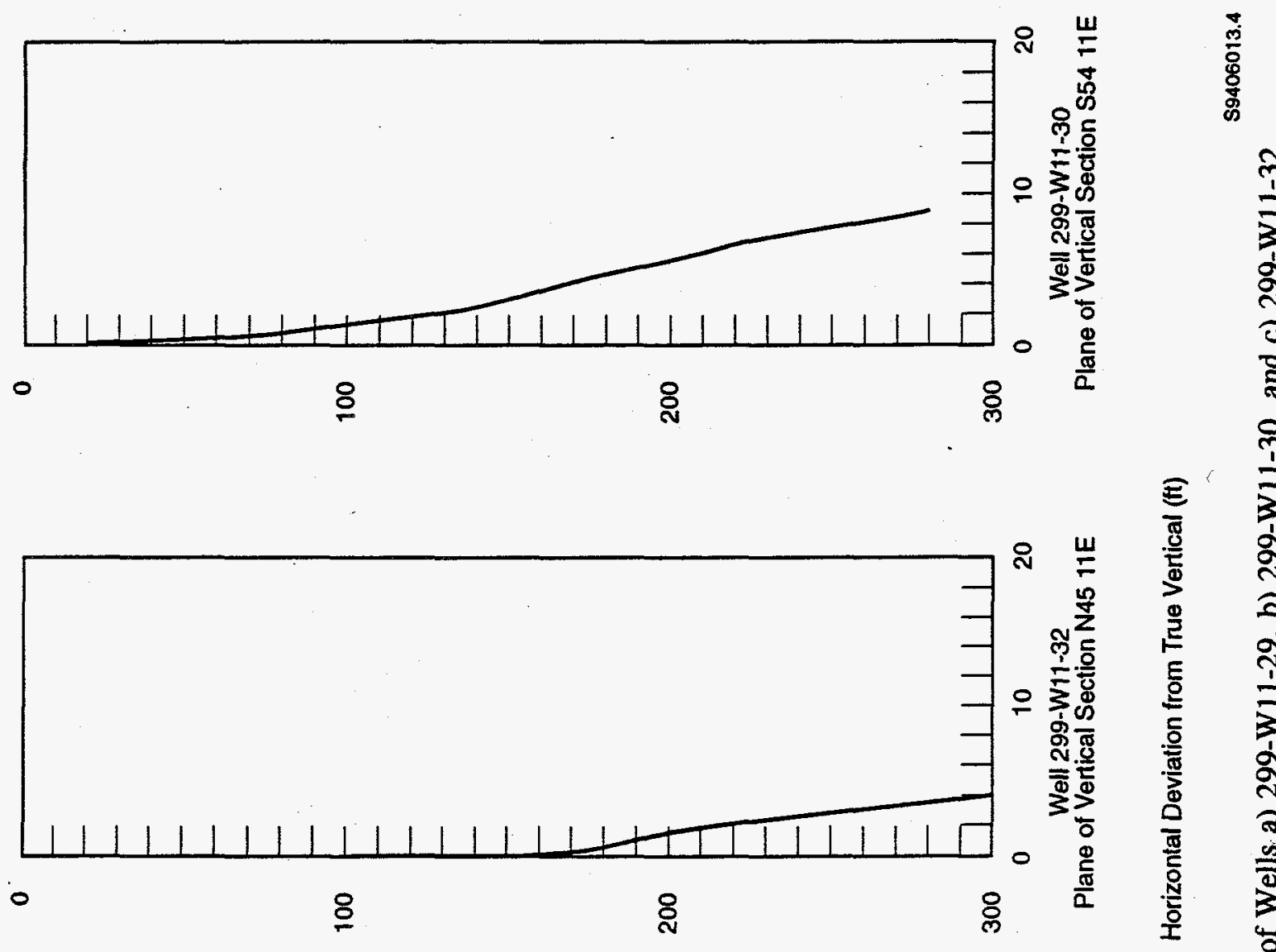

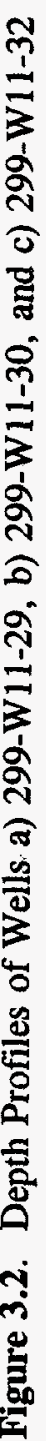

0

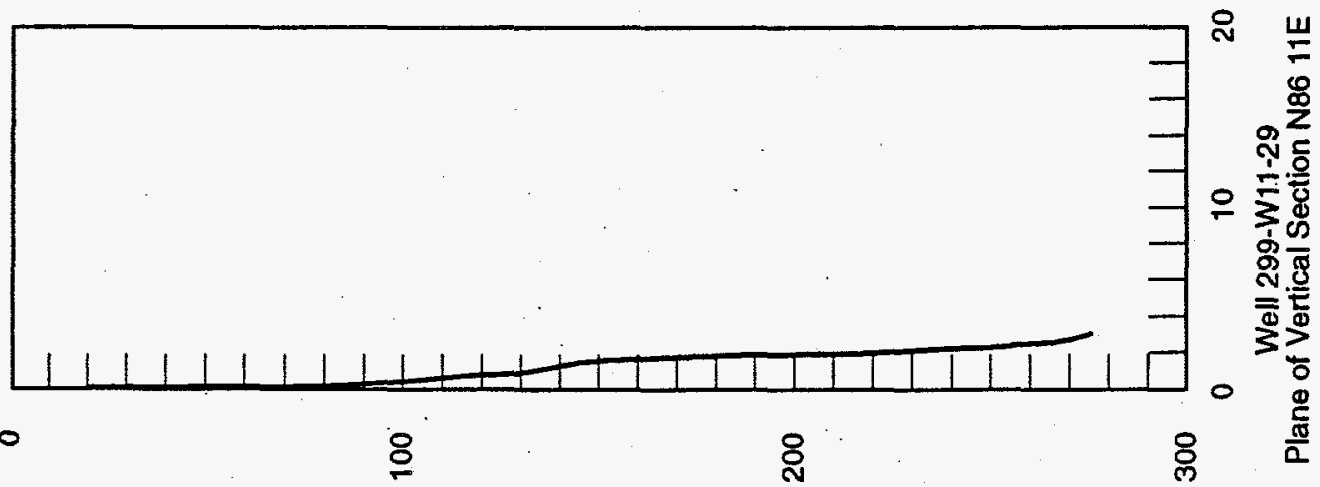

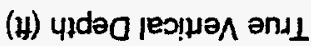




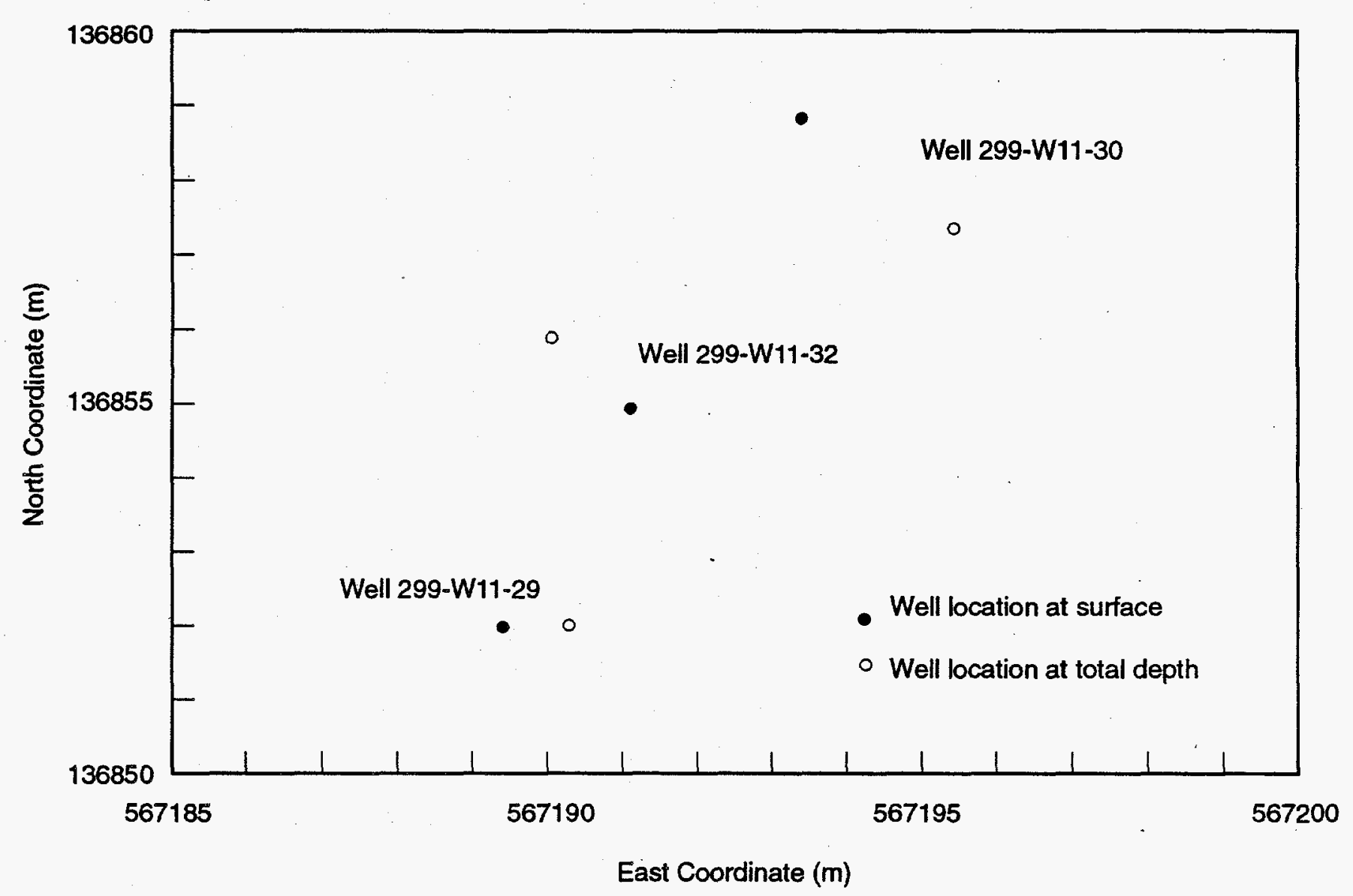

$\$ 9406013.3$

Figure 3.3. Plan View of Wells at the Surface and at Total Depth 


\subsection{Geologic Characterization}

The primary purpose of geologic characterization is to determine the baseline geologic conditions of the upper part of the aquifer formation and the unsaturated zone just above the water table. Geologic characterization discussed includes a description of the sediment physical properties, sediment chemistry, and geophysical logging. The physical properties discussed include lithologic description, particle size distribution, particle density (and porosity), mineralogy, and laboratory-measured hydraulic conductivity. Sediment chemistry includes carbon content, silica content, iron content, and Kjeldahl nitrogen and phosphorous content. Geophysical logging discussed includes neutron porosity, bulk density, and a brief description of natural gamma-gamma spectroscopy.

\subsection{Sediment Physical Properties}

Data about sediment physical properties contained in this report were collected from drill cuttings examined by Site personnel during well installations and by laboratory analysis of intact cores extracted during well installation. Samples were also collected during well installations for chemical analyses that were performed in laboratories under contract to PNL. Data interpretations presented below focus on the saturated zone lithology in which the in situ bioremediation demonstration will occur. Information about the unsaturated zone lithology is provided in less detail.

\subsubsection{Lithology}

Sediments encountered during well installations were described by a Site geologist who observed and recorded information about the properties of clast size; degree of consolidation (used to interpret cementation); mineralogy of clasts; reaction with hydrochloric acid $(\mathrm{HCl})$, which indicates calcium carbonate in the sediment matrix; and the mineral alteration products present. The classification scheme in use is defined by Folk (1968). The lithology of the saturated zone sediments, taken primarily from the geologic descriptions recorded during the installation of well 299-W11-32, is shown in Figure 4.1. Wells 299-W11-29 and 299-W11-30 were drilled in the saturated zone with a hard tool, which altered sediments and yielded lower quality samples. Well 299-W11-32 was drilled with a drive barrel in the saturated zone and yielded better quality samples.

The penetrated portion of the saturated zone and the lower $24 \mathrm{~m}(80 \mathrm{ft})$ of the unsaturated zone is made up of sediments of the middle Ringold unit, deposited within a fluvial environment of the ancestral Columbia River. Lindsey et al. (1991) classified these sediments as Ringold Gravel Unit E. Unit E sediments were derived from the Paleo-Columbia drainage, reflecting the mineralogy of the rocks along the Upper Columbia River drainage. These sediments, upon visual inspection, appear to be cemented with calcium carbonate and iron oxide. Alternate layers of poorly and well-cemented sediments were encountered during the installation of each well. The well-cemented layers were found to be harder than the surrounding formation and more difficult to penetrate during drilling. The wellcemented sediments retained the shape of the drilling tool with which they were extracted from the subsurface after being separated from the tool. In fact, it was difficult to break up the "clumps" of 


\section{$\tau \cdot t$}

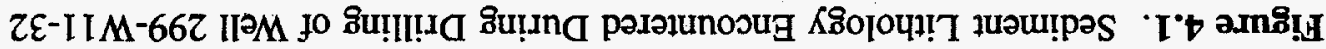

$1 \angle 0021+6 S$

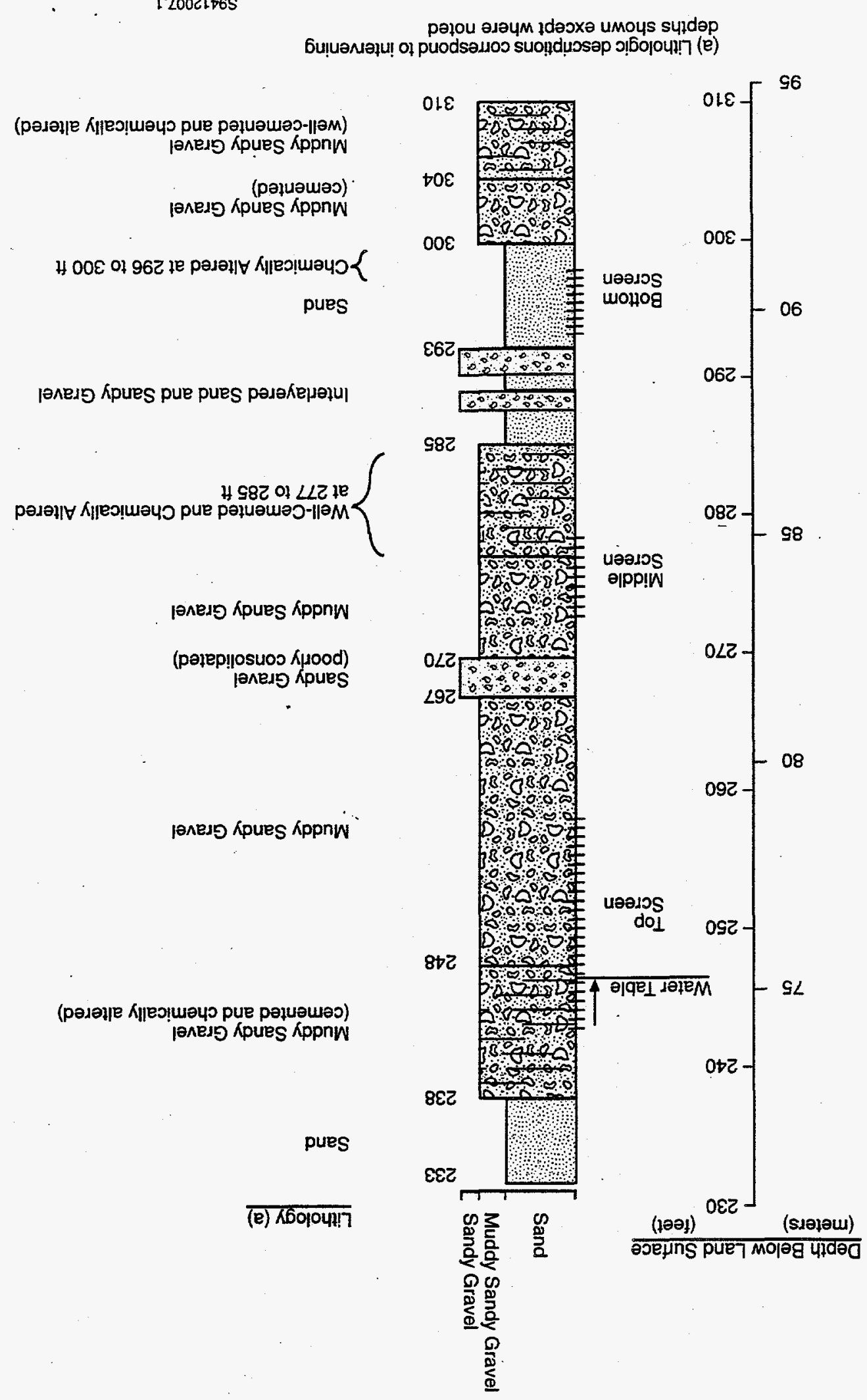


sediment for further visual inspection and for laboratory analysis of particle size distribution, as discussed in the following section. The sediments encountered during well installations are described in the following paragraphs.

The sediments of the middle Ringold unit are relatively consistent with depth in size distribution and mineralogy as interpreted from the sediment samples observed during drilling. The middle Ringold unit is primarily a muddy sandy gravel that, upon visual inspection, is composed of between $5 \%$ and $25 \%$ mud, between $20 \%$ and $50 \%$ sand, and between $35 \%$ and $70 \%$ gravel. The sand and gravel size fraction portions were relatively constant except in the sand lenses from 87 to $91 \mathrm{~m}$ and 71 to $73 \mathrm{~m}$ ( 286 to $300 \mathrm{ft}$ and 233 to $238 \mathrm{ft}$ ). These results are comparable with laboratory analysis results for particle size distribution, which are discussed in the following section. Minerals observed to be present were consistent throughout the penetrated middle Ringold unit: basalt, quartzite, felsics (granite minerals, undifferentiated), quartz, and some calcrete. Important observations were a significant reaction of the samples with $\mathrm{HCl}$ (indicating the presence of calcium carbonate), variable consolidation of the sediments, low drilling penetration rates, and the presence of chemical alteration products.

Well 299-W11-32 penetrated to a depth of $94 \mathrm{~m} \mathrm{(310} \mathrm{ft).} \mathrm{The} \mathrm{deepest} \mathrm{sediments} \mathrm{encountered}$ (below the 93-m [305-ft] depth), muddy sandy gravels, are well cemented, chemically altered, and strongly consolidated. From 91 to about $93 \mathrm{~m}$ ( 300 to about $305 \mathrm{ft}$ ), the sediments are made up of a cemented muddy sandy gravel that reacts with $\mathrm{HCl}$. The sediments do not appear to be chemically altered. From the 87 to $91 \mathrm{~m}$ ( 286 to $300 \mathrm{ft}$ ) depth, there is a change in the sediment lithology. The consolidation decreases significantly, and the particle size decreases to a sand. The upper part of the lithologic unit contains thin (0.3-m- [1-ft]-thick) layers of sandy gravel, interbedded with sand. From 88 to $90 \mathrm{~m}$ ( 290 to $296 \mathrm{ft}$ ), there is continuous, poorly consolidated sand that does not react with $\mathrm{HCl}$ (there is little indication of calcium carbonate present). However, from 90 to $91 \mathrm{~m}$ (296 to $300 \mathrm{ft}$ ), the matrix contains an unidentified brown-colored alteration product.

The sediments from the 76- to $87-\mathrm{m}$ (248- to $286-\mathrm{ft})$ depth are relatively uniform except for two thin layers, each roughly 0.6 to $1 \mathrm{~m}$ ( 2 to $3 \mathrm{ft}$ ) thick, contained within the interval. The majority of the sediments, classified as muddy, sandy gravels, are cemented and have a similar particle size distribution. The chemical composition of the cementation varies, but not the overall degree of consolidation. The first thin layer that differs from the surrounding sediments is at the $84-$ to $85-\mathrm{m}$ (277- to $280-\mathrm{ft}$ ) depth, which was observed in all of the boreholes drilled. These sediments were very well cemented, chemically altered, and more difficult to penetrate during drilling. They were also composed of a higher carbon content (discussed in the section on sediment chemistry). The clast size distribution within this thin layer was not found to vary significantly from those above or below. The major difference is the greater degree of consolidation and evidence of chemical alteration. Field observations that indicate the presence of chemical alteration include iron oxide stain in sediment matrix, greenish color to sediments, and mineral alteration rinds around sediment clasts. Small pieces of carbon material were also observed.

The second thin layer was encountered at a depth of approximately 81 to $82 \mathrm{~m}$ (267 to $270 \mathrm{ft}$ ), where the sediment consolidation decreased. There is a thin, less dense and higher porosity layer here, approximately 0.6 to $1 \mathrm{~m} \mathrm{(2} \mathrm{to} 3 \mathrm{ft}$ ) thick. The higher porosity for this layer is interpreted primarily from the geophysical logs. During drilling advancement, sediment from the surrounding formation 
sloughed more readily into the borehole at this depth than just above or below it, indicating a porous zone. However, a lithologic change was not discernable at this depth location because of the cable-tool drilling method used.

Between the 76- to $81-\mathrm{m}$ (248- to $267-\mathrm{ft}$ ) depth, the sediments are moderately consolidated without the significant development of chemical alteration products. Sediments reacted with $\mathrm{HCl}$ (indicating some calcium carbonate cement present). There was some rust coloration in the sediment matrix, indicating partial chemical breakdown of basalt clasts to iron oxides. These sediments are classified as muddy sandy gravel.

A well-cemented layer was encountered in the capillary fringe at a depth of $73 \mathrm{~m}(238 \mathrm{ft})$, and

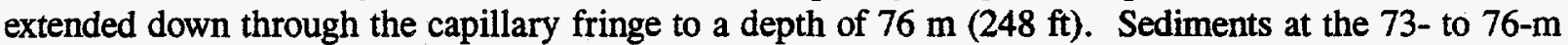
(238- to 248-ft) depth were classified as a muddy gravel and a muddy sandy gravel, based on the percentages of mud (clay and silt), sand, and gravel present. They were well cemented, and consequently well consolidated. Based on field observations, there were chemical alteration products and carbon chunks present in the sample.

The unsaturated zone sediments, which extend from a depth of $75 \mathrm{~m}(247 \mathrm{ft})$ to the ground surface are, in ascending order, middle Ringold unit, upper Ringold unit, and Hanford formation. The depths of the interpreted contacts and stratigraphic thicknesses are consistent with those described in Lindsey et al. (1991). Both the upper and middle Ringold units were deposited within fluvial environments of the ancestral Columbia River. The middle Ringold sediments that are present in the unsaturated zone are similar to those present in the saturated zone, classified by Lindsey et al. (1991) as Ringold Gravel Unit E. The sediment size distribution is relatively uniform with depth and is a muddy sandy gravel according to the Folk classification (Folk 1968) system. In addition, these sediments are relatively well cemented throughout the unsaturated zone. The sandy layer (described previously) present from approximately 71 to $73 \mathrm{~m}$ ( 233 to $238 \mathrm{ft}$ ) is the only departure from this distribution.

The upper Ringold unit is about $11 \mathrm{~m}$ (37 ft) thick, extending from the lower contact with the middle Ringold unit at a depth of $51 \mathrm{~m}(167 \mathrm{ft})$ to the contact with the Plio-Pleistocene unit at a depth of $40 \mathrm{~m}(130 \mathrm{ft})$. The upper Ringold sediments are sands and muddy sands, with pebble size clasts present in the uppermost $1.5 \mathrm{~m}(5 \mathrm{ft})$ of this unit. The contact between the upper Ringold and PlioPleistocene units is gradational.

The Plio-Pleistocene unit is composed of sandy mud with thin indurated layers of calcium-

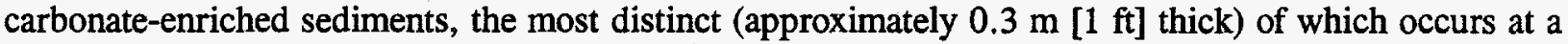
depth of $40 \mathrm{~m}(130 \mathrm{ft})$. These indurated layers of calcareous sediments can be referred to as calcrete (Machette 1985). The contact between the Plio-Pleistocene unit and the overlying early "Palouse" soil occurs at a depth of approximately $34 \mathrm{~m}(111 \mathrm{ft})$. The early Palouse soil typically contains less calcium carbonate content than the Plio-Pleistocene unit (Bjornstad 1990). The early Palouse soil, which was characterized by a high natural-gamma response in wells 299-W11-30 and 299-W11-32, consists of sandy mud about $3 \mathrm{~m}(10 \mathrm{ft})$ thick.

Hanford formation sediments intersected by these wells extend from the surface to a depth of about $30 \mathrm{~m}(100 \mathrm{ft})$, and are composed of sands and slightly gravelly sands. Deposited by Pleistocene cataclysmic floods, these sediments are likely to have accumulated in a transitional environment with water flow energy intermediate between the high-energy channel flows that deposited gravelly sediments and the low-energy slackwater zones that deposited sands and silty sands (Bjornstad et al. 1987). 


\subsubsection{Particle Size Distribution, Porosity, and Density}

Particle-size analyses provide a quantitative measure of the size and distribution of the particle grains. Both a dry-sieve and a wet-sieve method were used for laboratory analysis of particle size distribution. The most accurate results were obtained using the wet-sieve method, which was used to determine the clay-to-sand-sized particles (PNL Procedure JEA-2, Soil Texture Determinations and Preparation of Samples for Mineralogy Analysis by X-Ray Diffraction [XRD]). The dry-sieve method is used to determine the mud-to-gravel-sized particles (described in PNL-MA-567, SA-2, Sieve Procedure). The dry-sieve method allows the smaller-size fraction of consolidated sediments to be retained with the larger-size fraction. As a consequence, the dry-sieve analysis results are skewed toward the larger-size fractions than are actually present in the samples, and the smaller-size fraction is significantly less than the actual amount present. Because of potential bias with the dry-sieve method, greater consideration will be given to the results of the wet-sieve analyses; which were only done on samples from well 299-W11-32. Some of the samples from wells 299-W11-29 and 299-W11-30 were collected after hard-tool drilling. Particle-size distribution results of these samples may be skewed toward finer grain sediments because of pulverization by the hard-tool bit.

Sediment samples taken from the capillary fringe and saturated zone, which is in the middle Ringold unit, is primarily made up of sediments deposited by a high-energy flow regime, with particle size ranging from cobbles to clay ( $100 \mathrm{~mm}$ to $<0.004 \mathrm{~mm}$ in diameter, respectively). The nongravel particle size distribution was found to be relatively constant with depth; there is clay-, silt-, and sandsized sediment particles present in similar relative proportions at all depths in the saturated zone. Gravel is the most dominant particle size for all size ranges.

For all samples that were analyzed (by wet-sieve method), silt size fraction was 3 to 4 times the clay size fraction as the results show in Table 4.1. The absolute amount of clay present in the samples ranged from $5 \%$ to $10 \%$, and silt $17 \%$ to $25 \%$. Of those samples analyzed with the wet-sieve method, those with the largest fraction of sediments silt-sized or smaller (silt and clay) were the samples from 73 to $76 \mathrm{~m}$ (238 to $248 \mathrm{ft}$ ) in depth. Generally, for all samples the fraction of sediments that fall into the clay, silt, and sand (and larger) size categories is similar. The relatively uniform range in sediment size distribution suggests that although the absolute size of the clasts deposited together may vary, the relative abundance of each size remains constant. The fractions of clay-, silt-, and sand-sized particles for the same depths as Table 4.1 are shown in Figure 4.2.

Table 4.1. Sediment Size Distribution Using the Wet-Sieve Method for Clay-, Silt-, and Sand-Sized Categories

\begin{tabular}{lllllllll}
\hline \multicolumn{1}{c}{ Depth $(\mathrm{m})$} \\
\hline$\underline{72.2}$ & $\underline{72.8}$ & $\underline{73.2}$ & $\underline{74.1}$ & $\underline{75.3}$ & $\underline{78.0}$ & $\underline{82.9}$ & $\underline{88.1}$ & $\underline{92.7}$
\end{tabular}

$\begin{array}{llllllllll}\text { Sand (\%) } & 74 & 64 & 71 & 65 & 68 & 74 & 73 & 77 & 82 \\ \text { Silt (\%) } & 18 & 27 & 21 & 25 & 23 & 21 & 21 & 17 & 13 \\ \text { Clay (\%) } & 8 & 9 & 5 & 10 & 9 & 5 & 6 & 6 & 5 \\ & & & & & & & & & \\ \text { Clay/silt ratio } & 0.44 & 0.33 & 0.24 & 0.40 & 0.24 & 0.29 & 0.35 & 0.38 & 0.39 \\ \text { c+s/sand ratio } & 0.35 & 0.56 & 0.37 & 0.54 & 0.35 & 0.37 & 0.30 & 0.22 & 0.47\end{array}$




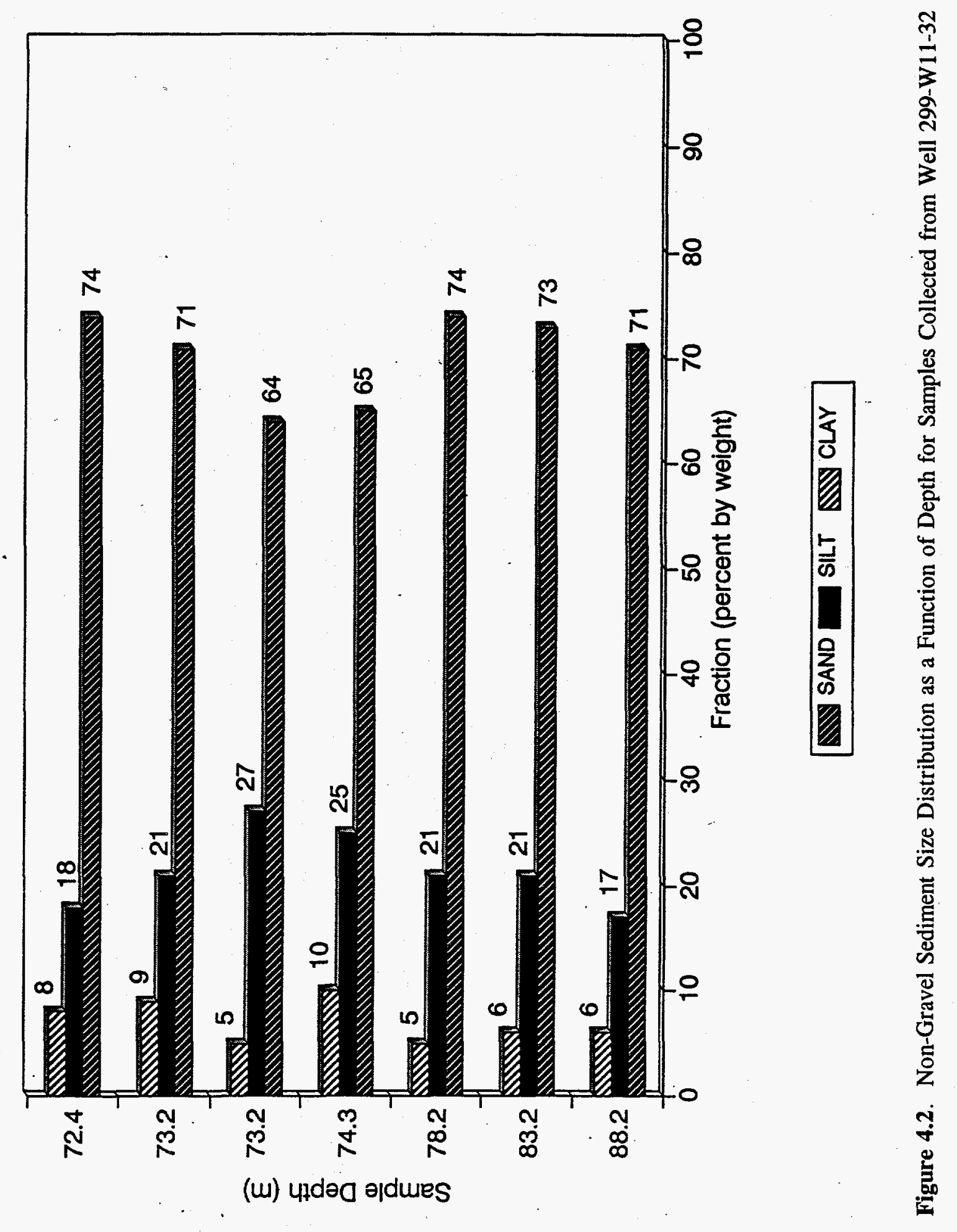


A stacked bar-graph of the dry-sieve analyses of samples combined from all three wells is presented in Figure 4.3. The plot indicates that gravel is the most dominant particle size, ranging between about $40 \%$ and $75 \%$ of the fraction for most of the samples. Sand is the next most dominant size, ranging between $20 \%$ and $45 \%$, for most of the samples collected. The smallest size fraction, made up of mud, is probably dominated by silt, as indicated from the wet-sieved results. Based on the sediment classification scheme according to particle-size distribution (Folk 1968), all depths except 75

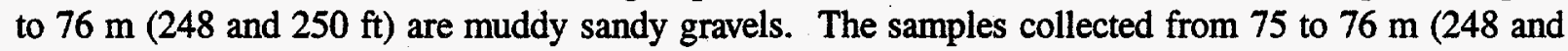
$250 \mathrm{ft}$ ) are classified as slightly muddy gravelly sands.

Particle density, bulk density, and porosity of five sediment samples from the saturated zone were analyzed. Porosity was calculated as the ratio of the difference between the bulk density and the particle density to the entire bulk density. The procedure used to measure particle density was taken from PNL-MA-567, SA-9, "Determining Particle Density." Bulk density is measured directly as the ratio of the weight to the volume of an intact sediment sample collected in a Lexan tube. The values determined for particle density, bulk density, and porosity are shown in Table 4.2.

\subsubsection{Mineralogy}

Mineralogy analyses were performed on the clay-sized fraction of the sediment samples from well 299-W11-32 using PNL Procedure JEA-3, Mineralogy Analysis of Soil Samples by X-Ray Diffraction (XRD). These samples represent the middle Ringold unit. Clay particles have a significantly larger surface area to volume ratio than the larger particles of silt and sand. As a consequence, there is a much greater potential for clay-sized particles to react with constituents in the surrounding ground water and influence the performance of the bioremediation demonstration. Clay minerals are likely to adsorb metals and anions present in ground water, isolating them from chemical interaction with other species present, or from microorganisms that may possibly use specific constituents as nutrients. In addition, clay minerals contain metals that may be accessible to microorganisms for chemical reactions that are not available in other mineral matrices (Gorby et al. 1994). With respect to the mineralogic content of the clay-sized fraction, the results of analyses done on sediment samples look relatively similar for all samples taken in the saturated zone. The clay sized fraction contained similar proportions of the following minerals: hornblende, quartz, feldspar, illite, kaolinite, chlorite, vermiculite, and smectite. When present, hornblende, kaolinite, chlorite, and vermiculite were at concentrations of less than $2 \%$. The percent by weight of the remaining minerals (smectite, quartz, feldspar, and illite) are shown in Figure 4.4.

Smectite, quartz, and feldspar were present in the highest concentrations. Smectite, also referred to as montmorillonite, constitutes approximately half of the clay-sized fraction with a range of $44 \%$ to $60 \%$ by weight. Smectite is a swelling clay that forms from alteration of mafic minerals exposed to high water contents and slow water travel time. Once exposed to moisture it has an extreme capacity for water absorption (Brownlow 1979). Its presence at proportions of up to $5 \%$ of the total sediment is likely to decrease the sediment porosity and permeability. Illite makes up between $2 \%$ and $4 \%$ of the clay-sized fraction. Although its mineral structure is similar to that of smectite, it is a nonswelling clay (Brownlow 1979). In the amounts that illite is present it is unlikely to influence the physical properties of water transfer or the chemistry of the biodegradation demonstration. The other minerals present in the clay-sized fraction, quartz and feldspar, are not clays and as such, not as reactive as smectite or illite. 


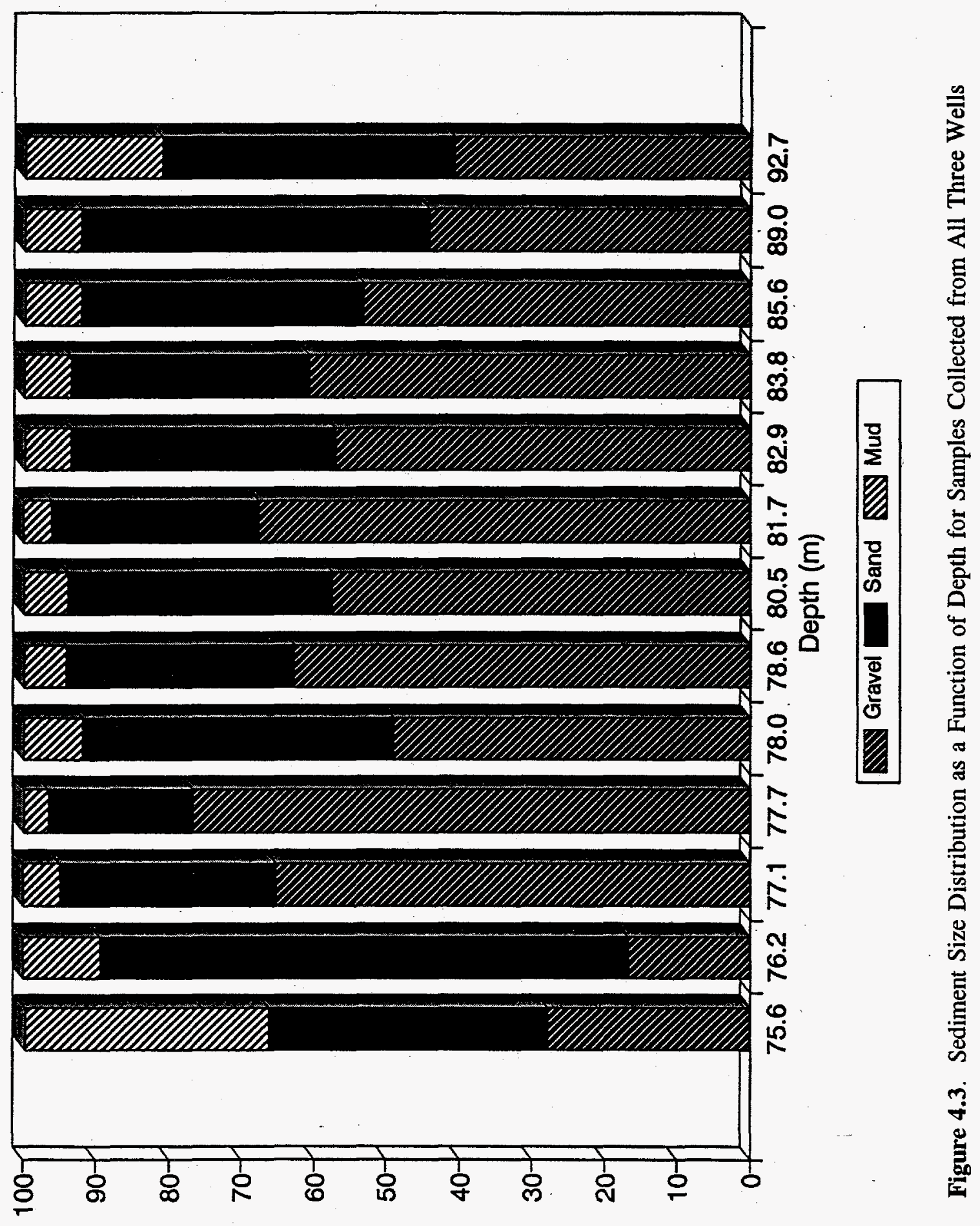

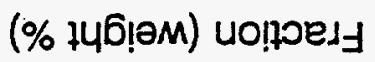


Table 4.2. Particle Density, Bulk Density, and Porosity for Sediment Samples from the Saturated Zone of Well 299-W11-32

\begin{tabular}{|c|c|c|c|c|c|}
\hline & & & epth (n & & \\
\hline & 83.8 & 85.0 & 88.7 & 89.0 & 93.3 \\
\hline Particle density & 2.68 & 2.78 & 2.65 & 2.64 & 2.66 \\
\hline Bulk density & 2.05 & 1.98 & 1.78 & 1.96 & 2.12 \\
\hline Porosity (\%) & 24 & 29 & 33 & 26 & 21 \\
\hline
\end{tabular}

\subsubsection{Laboratory-Measured Hydraulic Conductivity}

Vertical hydraulic conductivity was measured on intact sediment samples using a falling head permeameter procedure described in PNL-MA-567 (SA-5, "Falling Head Hydraulic Conductivity Procedure"). Samples analyzed were all $0.2 \mathrm{~m}(0.5 \mathrm{ft})$ in length, extracted from the subsurface in a lexan liner using a percussion-driven split spoon. The samples may have been compressed in the vertical direction during drilling. As a consequence, the results of the analyses may be lower than the actual vertical hydraulic conductivity of the intact sediments. The amount of compression is likely to be less than $5 \%$ of the original sample length based on field observations during drilling. The influence of compression on the laboratory-measured values may have decreased the hydraulic conductivity. Laboratory analyses of samples from well 299-W11-32 show hydraulic conductivity values ranging between $10^{-3}$ and $10^{-7} \mathrm{~cm} / \mathrm{sec}$, as shown in Table 4.3 .

In general, the laboratory-measured hydraulic conductivity showed lower values with greater variability than results from the hydrologic field tests (discussed later). Laboratory hydraulic conductivity results are likely to show lower values than the field tests for the following reasons. First, the laboratory tests measure vertical conductivity, which is commonly less than horizontal hydraulic conductivity because of horizontal bedding and lamination. Horizontal bedding and lamination are a result of preferred orientation of sediment particles with their long axes parallel to the bedding plane. The field hydrologic tests were designed to measure horizontal hydraulic conductivity. In addition, as measurements may have been compressed in the vertical direction by the split-spoon sampling technique. Hydrologic field test results yield mean values representative of the formation lying between the test wells over the depth of the test intervals, whereas laboratory hydraulic conductivity reflect depth-discrete measurements from core samples, thereby yielding greater variability.

\subsection{Sediment Chemistry}

Sediment chemistry was analyzed to determine the constituents present that may influence the biodegradation demonstration. Those constituents that were identified to be of consequence to the in situ biodegradation of $\mathrm{CCl}_{4}$ are carbon, iron, nitrogen, and phosphorous. Sample results presented were taken from all three wells for carbon analyses. Results from samples collected from well 299-W11-32 are presented for the remaining chemical constituents. 


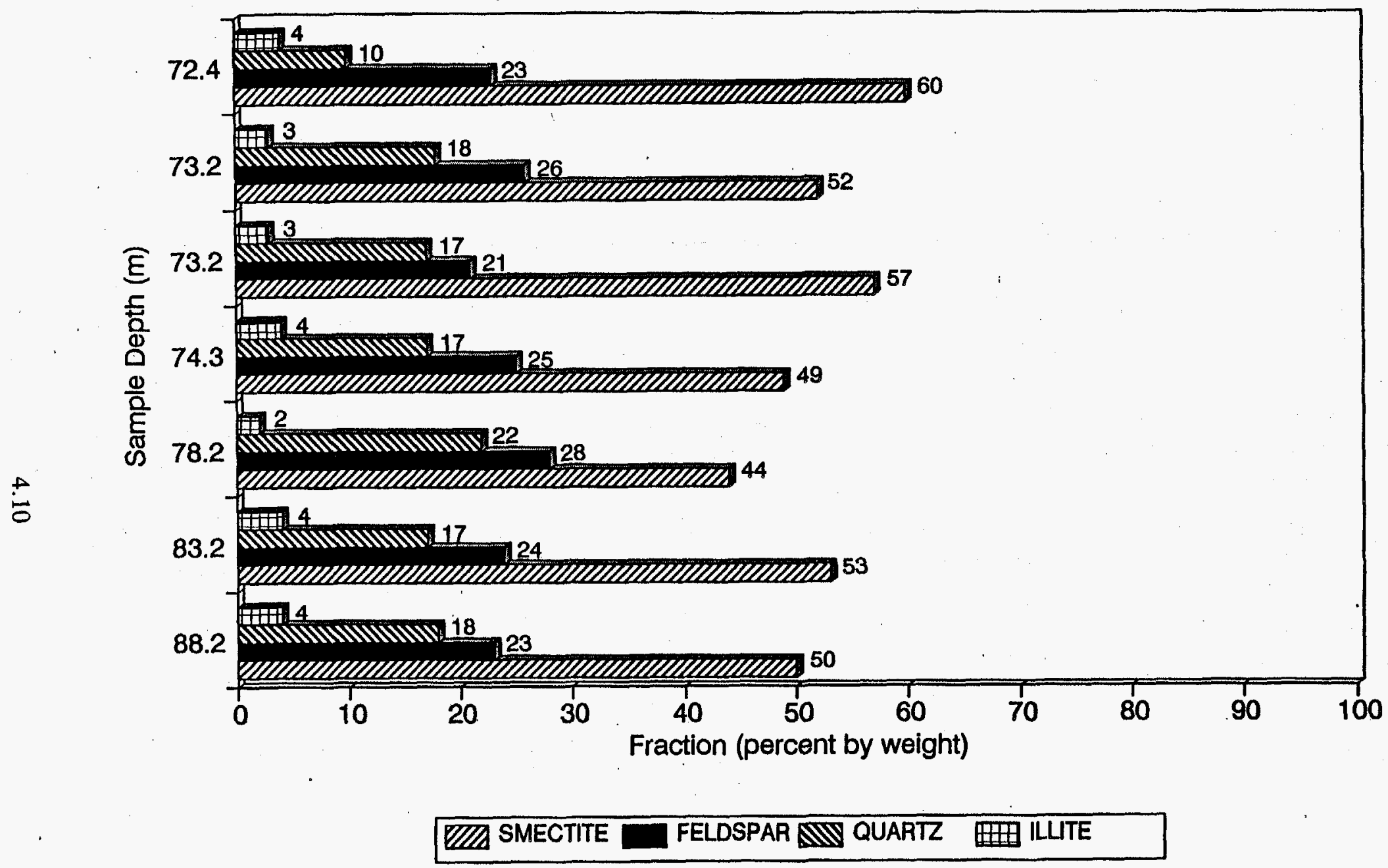

Figure 4.4. Clay-Sized Fraction Mineralogy as a Function of Depth for Sediment Samples Collected from Well 299-W11-32 
Table 4.3. Hydraulic Conductivity (K) Values Measured with Falling Head Permeameter on Samples from Well 299-W11-32

\begin{tabular}{|c|c|c|c|c|}
\hline Depth (m) & $\mathrm{K}(\mathrm{cm} / \mathrm{sec})$ & $\begin{array}{c}\text { Degree of } \\
\text { Consolidation }\end{array}$ & $\begin{array}{c}\text { Carbonate } \\
\text { Content } \\
(\%)\end{array}$ & Lithology \\
\hline 75.4 & $2.14 \mathrm{E}-04$ & moderate & 4 & Muddy Sandy Gravel \\
\hline 77.1 to 77.2 & 2.75E-07 & moderate & & Muddy Sandy Gravel \\
\hline 77.7 to 78.2 & $6.19 \mathrm{E}-06$ & moderate & 0.7 & Muddy Sandy Gravel \\
\hline 83.7 to 83.8 & $7.46 \mathrm{E}-05$ & poor & & Muddy Gravel \\
\hline 83.8 to 84.0 & $6.06 \mathrm{E}-05$ & poor & & Muddy Gravel \\
\hline 84.9 to 85.0 & 5.17E-06 & strong & 7 to 8 & Muddy Sandy Gravel \\
\hline 89.0 to 89.2 & $1.07 \mathrm{E}-04$ & poor & 0.6 & Sandy Gravel \\
\hline 92.7 to 93.0 & $3.09 \mathrm{E}-06$ & strong & & Muddy Șandy Gravel \\
\hline Average Upper Screen & $7.35 \mathrm{E}-5$ & & & \\
\hline Average Middle Screen & $4.68 \mathrm{E}-5$ & & & \\
\hline Average Lower Screen & $1.07 \mathrm{E}-4$ & & & \\
\hline
\end{tabular}

\subsubsection{Carbon Content}

Analyses were done to determine the content of both organie and inorganic carbon present in the sediments. Organic chemicals, such as carbon tetrachloride and acetate, which will be part of this demonstration, often sorb to organic carbon present in the aquifer sediments, removing them from transport in the ground water. The relative amount of inorganic carbon present indicates how much calcium carbonate cement is present in the sediments. Cementation was observed in samples collected during drilling, including core samples for conducting laboratory hydraulic conductivity analyses. The carbonate analysis results are an indication of the relative amount of calcium carbonate cementation present. Other cementing agents may include silica and iron oxide (discussed below). Cementation appears to decrease the hydraulic conductivity of the sediments than if cementation was not present. Hydraulic conductivity measurements on sediment samples are discussed in Section 4.3.

Carbon analyses were done using a coulometric technique to detect the total amount of carbon present and the inorganic carbon content. Organic carbon was calculated as the difference between the inorganic carbon and the total carbon. All inorganic carbon was assumed to be present as carbonate, and the amount of carbonate calculated from that. The results show that carbonate is present in amounts less than $10 \%$. Calcium carbonate is present in cemented zones of Hanford area sediments in proportions of up to $40 \%$ of the sediment in cemented horizons, as is found in the Plio-Pleistocene unit that separates the Ringold and Hanford formations (Bjornstad 1990).

Carbon content analyses were done on sediments from all three of the wells installed. The maximum carbon contents were about $1 \%$ (by weight), with the highest at $1.12 \%$. Sediment analyzed from the 85- to 85.3-m (279- to 280-ft) depth from both wells 299-W11-29 and 299-W11-30 also showed a total carbon content of about $1 \%$, with the organic carbon making up between $0.60 \%$ and $0.85 \%$ of 
sediment. The carbon contents of all five samples from well 299-W11-32 were less than 1\%, with the highest carbon content from the $93-\mathrm{m}(305-\mathrm{ft})$ depth $(0.75 \%)$. The organic carbon contents of all sediment samples from well 299-W11-32 was less than $0.1 \%$. The total carbon content of sediments samples taken from all other horizons in both wells 299-W11-30 and 299-W11-32 was relatively constant, between 0.015 and $0.079 \%$ for the depths shown in Figures 4.5 and 4.6.

\subsubsection{Silica Content}

Amorphous silica $\left(\mathrm{SiO}_{2}\right)$ was measured to determine whether some of the cementation observed in the saturated zone sediments during borehole drilling was composed of silica. The low carbonate content measurements when compared with the observed sediment induration suggested that another cement was present. Amorphous silica content determinations were made on leachate from the sediment extracted using a method defined by Follett et al. (1965). The silica content was measured in the leachate using a method defined by Govett (1961). Silica was measured only in an unbound state, the form it would be present in if precipitated as a cement. Silica present in crystal matrix (i.e., as quartz or other minerals) is not included in the contents shown in Table 4.4.

The amount of amorphous silica in the eleven samples showed the silica content to be relatively uniform in both the capillary fringe and saturated zone. Amorphous silica was found to comprise a small portion of the sediment, consistently less than one thousandth of the sediment mass. Table 4.4 shows the silica content measured as a function of depth from the ground surface.

\subsubsection{Iron Content}

Iron present in the sediments may have an impact on the performance of the in situ bioremediation demonstration results. Iron present in layered silicates may be available as a nutrient for iron-reducing microorganisms. Gorby et al. (1994) have found that iron present in clays may be reduced by ironreducing microorganisms and then reacting with $\mathrm{CCl}_{4}$.

Iron content and oxidation state for sediments from well 299-W11-32 were analyzed on seven samples from the saturated zone and one from the capillary fringe. Analyses were done using a method modified by Templeton et al. (1994) from Komadel and Stucki (1988) using phenanthroline. Iron content (shown in Figure 4.7) was relatively uniform with depth, ranging from $2.39 \%$ to $3.44 \%$, with approximately $2 / 3$ of the total iron present as ferric iron. The large percentage of ferric iron present indicates that the shallow saturated zone and capillary fringe from which these samples are collected suggests an oxidizing environment. The results of water chemistry analyses, discussed in Section 7.0, provide evidence for a similar conclusion.

\subsubsection{Kjeldahl Nitrogen and Phosphorous Content}

Both nitrogen and phosphorous act as nutrients for microorganisms that will be stimulated during the bioremediation demonstration. Phosphorus is required by microorganisms to regulate the amount of energy generated and consumed (Chapelle 1993). 


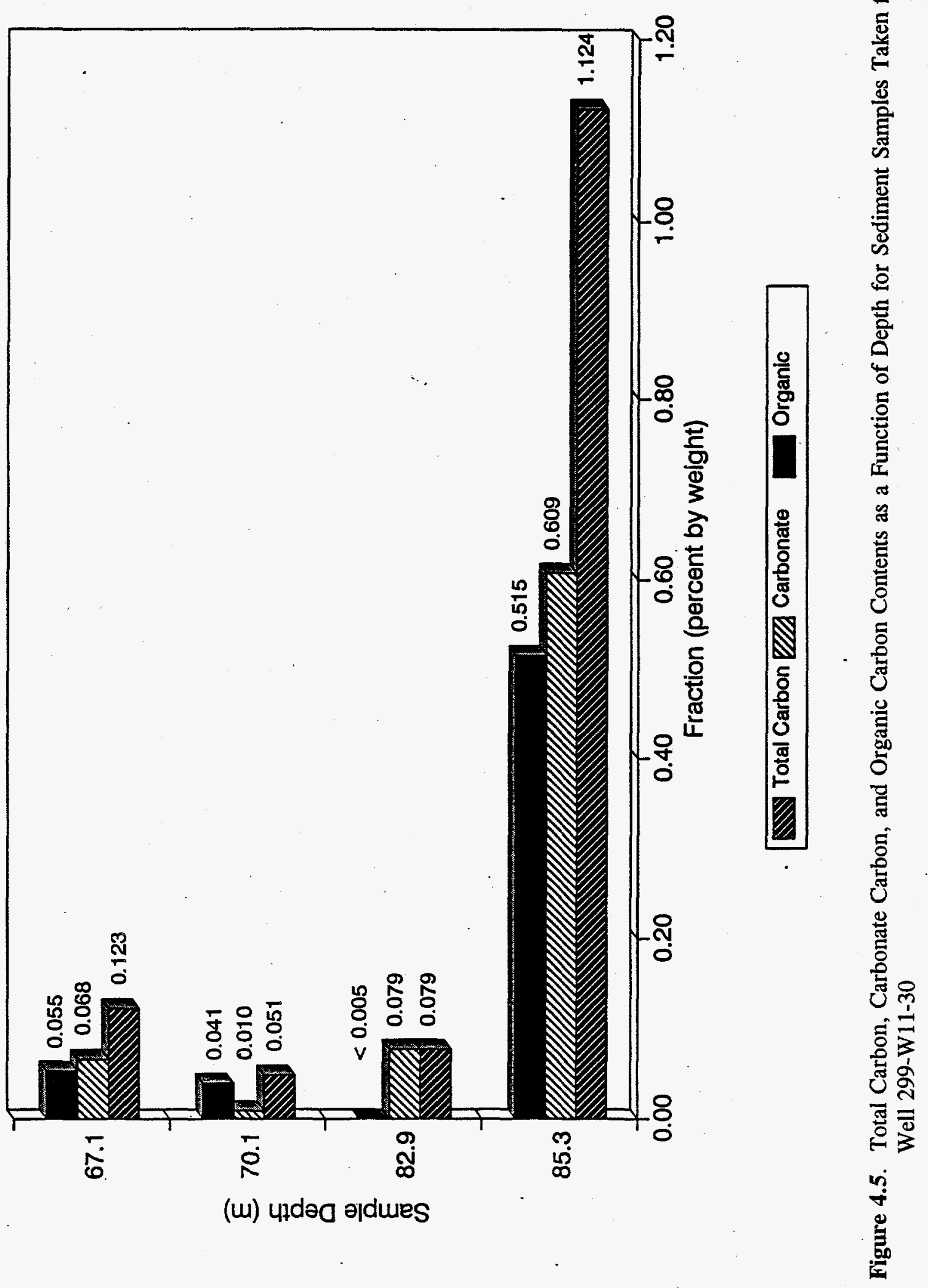




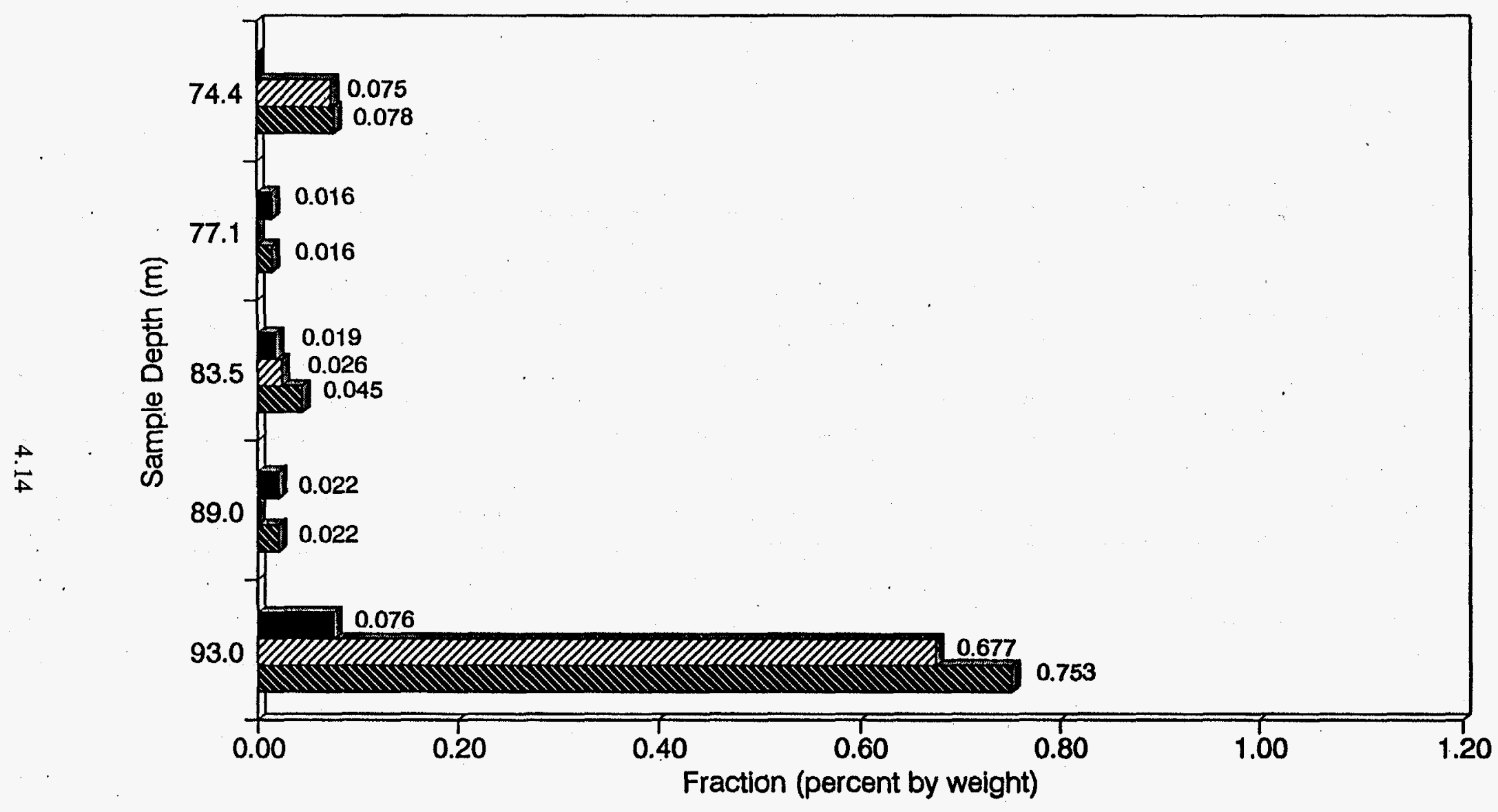

MIII Total Carbon WOA Carbonate $\square$ Organic

Figure 4.6. Total Carbon, Carbonate Carbon, and Organic Carbon Contents as a Function of Depth for Sediment Samples Taken from Well 299-W11-32. 
Table 4.4. Amorphous Silica Content of Middle Ringold

Sediments Collected from Well 299-W11-32

\begin{tabular}{cc} 
Depth $(\mathrm{m})$ & \multicolumn{2}{c}{ Silica Conten } \\
\cline { 2 - 2 } 74 & 0.061 \\
78 & 0.049 \\
79 & 0.063 \\
81 & 0.069 \\
82 & 0.074 \\
84 & 0.062 \\
88 & 0.047 \\
90 & 0.038 \\
91 & 0.069 \\
93 & 0.086
\end{tabular}

As with the silica determinations, the total amount of nitrogen or phosphorous present in the mineral's structure is not relevant to the demonstration. The amount available for reaction at the surface of the sediment clasts with ground water or microorganisms is what may influence the performance of the demonstration. Consequently, surface leachable concentrations of nitrogen and phosphorous were measured in these analyses. The results of these analyses are intended to help in the determination of the amount of each of these constituents that would be available for consumption by chemical processes in the aquifer.

Kjeldahl Nitrogen and phosphorous content was determined for five samples; one from the capillary fringe, and four from the saturated zone from well 299-W11-32. Kjeldahl nitrogen was determined using an acid digestion in the presence of a catalyst to convert nitrogen to ammonium salts. The resulting salts are decomposed in a hot alkaline solution from which the ammonia is recovered by distillation and measured by titration. Phosphorous content was determined using Inductively Coupled Plasma (ICP) Atomic Emission Spectroscopy on a solution generated by digesting sediments with nitric acid and refluxing with perchloric acid. All analyses were done by Huffman Laboratories in Golden, Colorado, on a leachate derived from sediments. The samples showed a relatively uniform Kjeldahl nitrogen content with depth; either $0.001 \%$ or $0.002 \%$ by weight of the sample was available Kjeldahl nitrogen. Total phosphorous content was also low, ranging from $0.027 \%$ to $0.053 \%$ of the sediment mass.

\subsubsection{Discussion}

The saturated zone sediments at the bioremediation demonstration site lie within the middle unit of the Ringold Formation. These sediments are characterized by 1) primarily muddy sandy gravels, 2) a relatively uniform size distribution with depth, 3) variable (poor to strong) consolidation, 4) variable laboratory-measured hydraulic conductivity, 5) variable neutron-porosity and bulk density log response, and 6) low carbon content. 

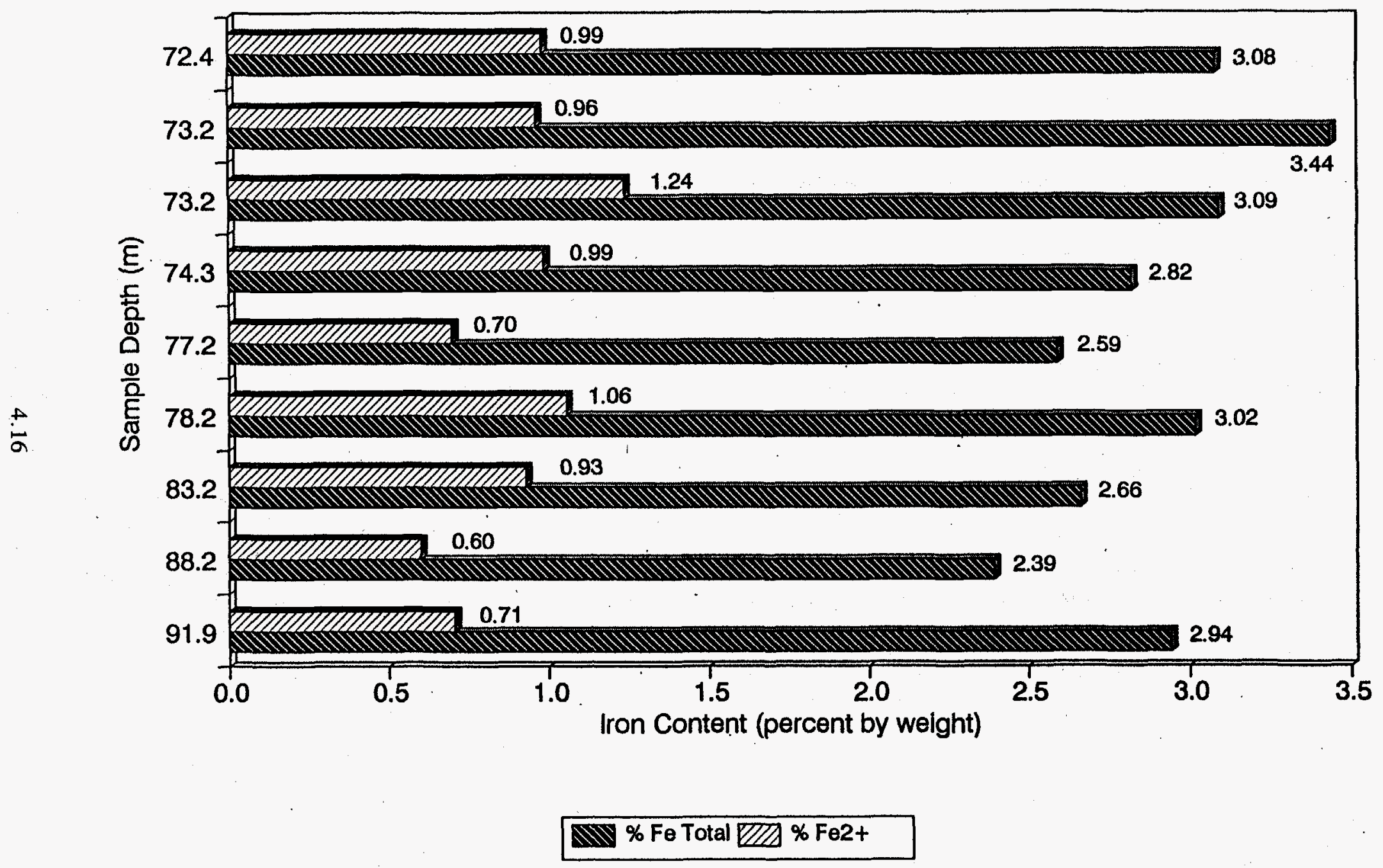

Figure 4.7. Iron Content as a Function of Depth for Sediment Samples Collected from Well 299-W11-32 
The sand and gravel sediments of the middle Ringold unit were deposited by a high-energy, fluvial system (river channel facies) associated with wide and shallow channels (Bjornstad 1990; Lindsey et al. 1991). Following deposition, secondary processes altered the sediments. These processes include cementation, compaction, and subsurface chemical alteration.

The poor-to-strong consolidation of the sediments is a result of compaction and various degrees of cementation. Although the calcium carbonate content was low (less than $1 \%$ by weight), cementation, concurrent with chemical alteration, appears to be present at frequent depths throughout the saturated interval. In a few cases, cementation was observed without chemical alteration of the grain particles, which may indicate evaporation of the deposited sediments after burial. The highest calcium carbonate concentrations, measured at depths of 85 to $93 \mathrm{~m}$ ( 280 and $305 \mathrm{ft}$ ), correlates with the most prominently consolidated materials encountered. Visual inspection of the sediments at these depths also indicated more evidence of chemical alteration products than at other depths. The presence of significant iron oxide staining indicates that iron oxide may also be a cementing agent. These depths were also characterized by a low neutron-porosity log response and high bulk density log response.

Two mechanisms of calcium carbonate cementation have been proposed. During exposure to the atmosphere, precipitates accumulated within the sediment matrix as a result of evaporation, thereby cementing the particle grains together. It is also suggested that subsurface microbial activity may play a role in altering the character of the sediments, as indicated by the presence of calcium carbonate. Monger et al. (1991) found that calcium carbonate can be precipitated by microorganisms.

The lack of calcium carbonate content and chemical alteration products, as determined by field observation, in the poorly to moderately consolidated sediments indicate that compaction was a secondary process. Calcium carbonate content at these depths was negligible (less than $0.1 \%$ by weight). Iron oxide measured in these sediments was low, approximately $2 \%$ by weight.

Most of these depths are characterized by moderate-to-high neutron-porosity log response and lowto-moderate bulk density log response. Laboratory-measured hydraulic conductivity varies significantly over the saturated interval, but correlates poorly with consolidation of the sediments.

\subsection{Geophysical Logging}

Well 299-W11-32 was drilled with a cable tool rig. Borehole geophysical logging was conducted on September 18, 1993, after drilling reached total depth but before completion activities began. A 30.5-cm (12-in.)-diameter carbon-steel temporary casing was pounded down the borehole as it was deepened, preventing borehole collapse in unconsolidated formations. The geophysical logs were run through 12-in. $(30.5-\mathrm{cm})$-diameter, carbon-steel well casing, which extended from the surface to a total depth of approximately $94 \mathrm{~m}$ ( $310 \mathrm{ft})$. The precision of measured depths are estimated to be \pm 3 in. $( \pm 8 \mathrm{~cm})$, with an accuracy of $\pm 1 \mathrm{ft}( \pm 0.3 \mathrm{~m})$. All depths were measured from ground surface.

Geophysical logging included borehole-compensated neutron-neutron porosity. This log responds to the hydrogen concentration in the formation surrounding the borehole. The compensated neutron logging tool contains a neutron source and two thermal neutron detectors, which are contained in the sonde mandrel and do not protrude from the main body of the tool. A 16 -curie $\mathrm{Am}^{241} \mathrm{Be}$ source emits $4 \mathrm{MeV}$ neutrons. The source strength and near and far detector spacing result in a depth of 
investigation of approximately $0.3 \mathrm{~m}(1 \mathrm{ft})$. The borehole and casing effects are greatly reduced by taking the ratio of the near and far detector count rates. The neutron logging tool is positioned against the borehole wall with a large bowspring. The tool is calibrated in known porosities and matrices in the laboratory, and the calibration is incorporated into the displayed results.

Thermal neutron porosity logs are calibrated in three matrix types: limestone, sandstone, and dolomite. The data were recorded assuming a limestone matrix. If the matrix material is sandstone, four porosity units (i.e., $4 \%$ ) must be added to the displayed results to obtain a calibrated and matrix sandstone-corrected porosity.

The neutron logging data are a measure of the hydrogen content of the formation. Neutrons are electrically neutral particles each having a mass almost identical to the mass of a hydrogen atom. High-energy neutrons are continuously emitted from a radioactive source positioned in the logging tool. These neutrons collide with nuclei of the formation materials, like billiard balls colliding on a billiard table. With each collision, each neutron loses some of its energy. The amount of energy lost per collision depends on the mass of the nucleus with which the neutron collides. The greater energy loss occurs when the neutron strikes a nucleus with practically equal mass (i.e., a hydrogen nucleus). Collisions with heavy nuclei do not slow the neutron very much. Thus, the slowing down of neutrons depends largely on the amount of hydrogen in the formation. Within a few microseconds the neutrons slow down via successive collisions to thermal velocities, corresponding to energies around $0.025 \mathrm{eV}$. The near and far thermal detectors count thermal neutrons. Thermal neutron count rate is inversely proportional to the hydrogen concentration, or the porosity.

The neutron log was used to estimate the total porosity profile of the formation within the saturated zone. The porosity calculation results are based on the assumption that hydrogen content in the formation is predominantly in the form of water. This assumption is logical because the clay content, which contains hydrogen, is small (i.e., $\leq 10 \%$ of the sediment fraction). It is also assumed that the formation pore spaces are saturated with water and there are no water-filled cavities adjacent to the casing (i.e., the casing material is in complete contact with the formation). Consequently, the content of hydrogen detected is proportional to the total porosity of the formation.

The neutron porosity profile and corresponding lithology (taken from Figure 4.1) as a function of depth is shown in Figure 4.8. The porosity axis on the graph increases from right to left, from $0 \%$ to $60 \%$. The profile shows that the porosity ranges between approximately $20 \%$ and $55 \%$, with major inflections at depths of approximately $78,81,84,88$, and $91 \mathrm{~m}(256,267,275,288$, and $298 \mathrm{ft})$. The highest porous zones are indicated at depths of $\leq 78 \mathrm{~m}, 81$ to $84 \mathrm{~m}$, and 88 to $91 \mathrm{~m}$ ( $\leq 256 \mathrm{ft}, 267$ to $275 \mathrm{ft}$, and 288 to $298 \mathrm{ft})$. A sharp inflection at the 76-m (248-ft) depth represents the air-water interface, which corresponds with water-level measurements. However, neutron porosity cannot be justifiably estimated above about the 78-m $(255-\mathrm{ft})$ depth because of spurious effects caused by the airwater interface. A sharp inflection at the $82-\mathrm{m}(268-\mathrm{ft})$ depth may be the result of a water-filled cavity adjacent to the casing, caused by sloughing of the formation during drilling.

Geophysical logging also included bulk density. The borehole-compensated gamma-gamma density $\log$ responds to the electron density of the formation surrounding the borehole and can be related to density porosity. The compensated density logging tool contains a gamma-ray source and two Na-I scintillation gamma-ray detectors, which are contained in a side-mounted skid. The skid protrudes from the main body of the tool and is forcefully positioned against the side of the borehole. A 


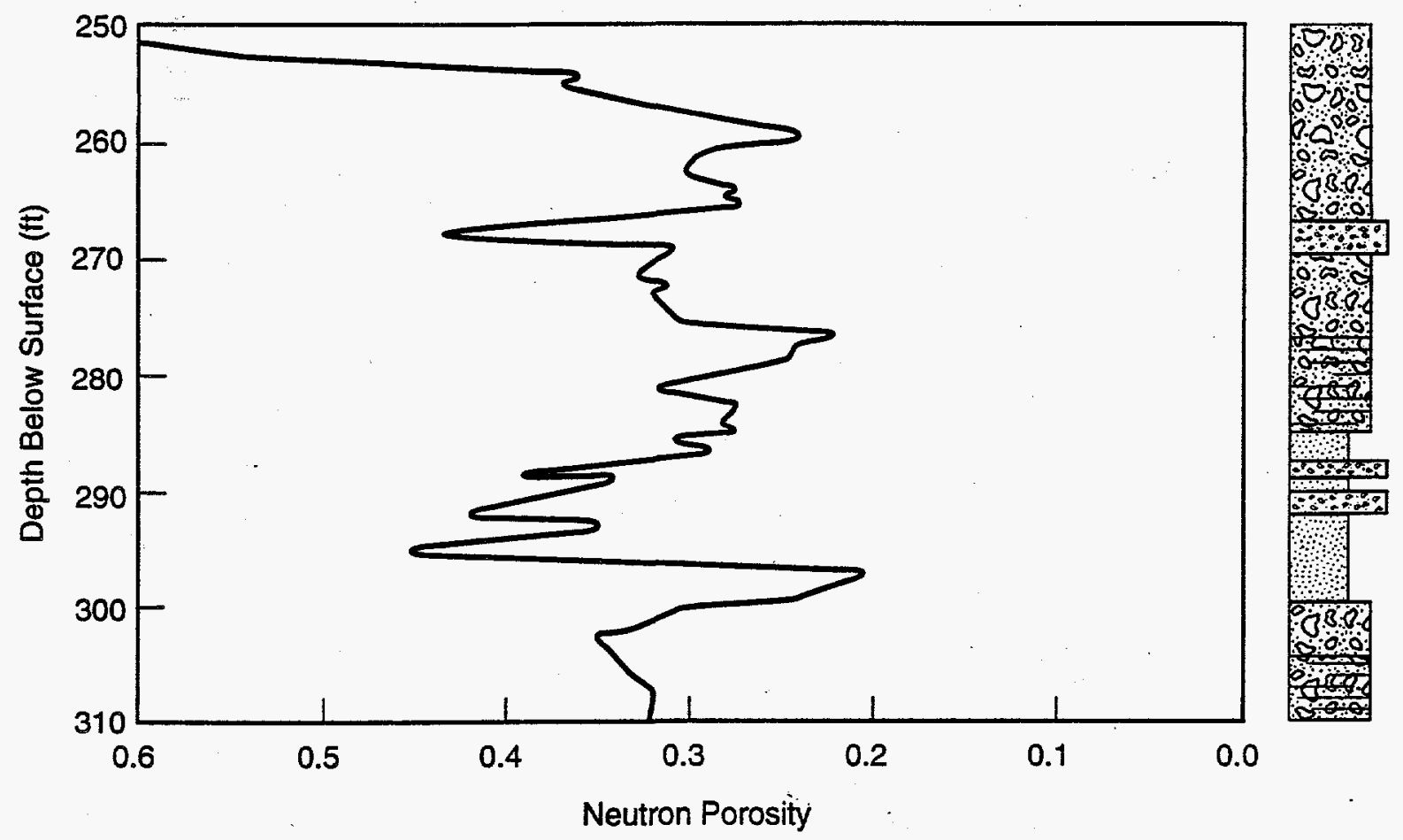

$\$ 9412007.3$

Figure 4.8. Neutron Porosity Log of Well 299-W11-32

1.7-curie ${ }^{137} \mathrm{Cs}$ source emits $662 \mathrm{KeV}$ gamma rays. The source strength and detector spacing result in a depth of investigation of approximately $10.2 \mathrm{~cm}(4 \mathrm{in}$.$) . Density tools are calibrated in known$ laboratory density models. Density logs can be corrected through casing, although these types of corrections are not standard practice. The density log response through casing will be investigated. Therefore, known calibration results will be available in the future. Perhaps the borehole geophysical through-casing logging correction for density could be normalized with core data.

The density porosity can be calculated from the formation bulk density log data. Assuming the formation $2 Z / A=1$, where $Z$ equals the atomic number and $A$ equals the atomic weight, the formation electron density is approximately equal to the formation bulk density. The density porosity is computed from the bulk density, grain density, and interstitial fluid density, as follows:

$$
\Phi=\frac{\rho_{\mathrm{m}}-\rho_{\mathrm{b}}}{\rho_{\mathrm{m}}-\rho_{\mathrm{i}}}
$$

where $\Phi=$ density porosity

$\rho_{\mathrm{m}}=$ matrix density

$\rho_{\mathrm{b}}=$ bulk $(\log )$ density

$\rho_{\mathrm{i}}=$ interstitial fluid density. 
The bulk density profile and corresponding lithology (taken from Figure 4.1) as a function of depth is shown in Figure 4.9. The bulk density data were corrected for the density of the carbon-steel casing material, assuming a wall thickness of $0.95 \mathrm{~cm}(0.375 \mathrm{in}$.). The profile shows that the bulk density ranges between approximately 1.5 to $2.5 \mathrm{gm} / \mathrm{cm}$. The interstitial fluid density is assumed to be $1 \mathrm{gm} / \mathrm{cm}$. The logging data were recorded assuming a limestone matrix, which has a matrix density of $2.71 \mathrm{gm} / \mathrm{cm}$. Of the matrix types used for calibrating the log readings, sandstone is more representative of the formation than limestone. To obtain a sandstone matrix-corrected porosity (from a limestone matrix porosity), $4 \%$ must be added to the porosity results. Insertion of these numbers in the above equation and correcting for the matrix type yields density porosity in the range of approximately $15 \%$ to $75 \%$, as shown on the plot.

Figure 4.9 shows that major inflections occur at depths of approximately $77,81,84,88$, and $91 \mathrm{~m}$ $(253,266,274,288$, and $297 \mathrm{ft})$. The highest porous zones are indicated at depths of $77 \mathrm{~m}, 81$ to

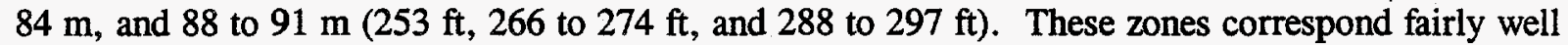
with those identified from the neutron porosity log. Again, similar to the neutron porosity $\log$, a sharp inflection at the $82-\mathrm{m} \cdot(268-\mathrm{ft})$ depth may be the result of a water-filled cavity adjacent to the casing.

Geophysical logging also included natural gamma-ray spectroscopy. Two bismuth germanate scintillation detectors record the natural gamma-ray energy spectra emitted by the formation. These spectra are analyzed for naturally occurring radioactive isotopes of thorium, uranium, and potassium. The thorium and potassium data are used to interpret formation clay types. Preliminary natural gamma-ray spectroscopy data qualitatively show very low concentrations, indicating that clay content in the formation is not significant. 'A quantitative interpretation of the data will be incorporated in a subsequent report. 


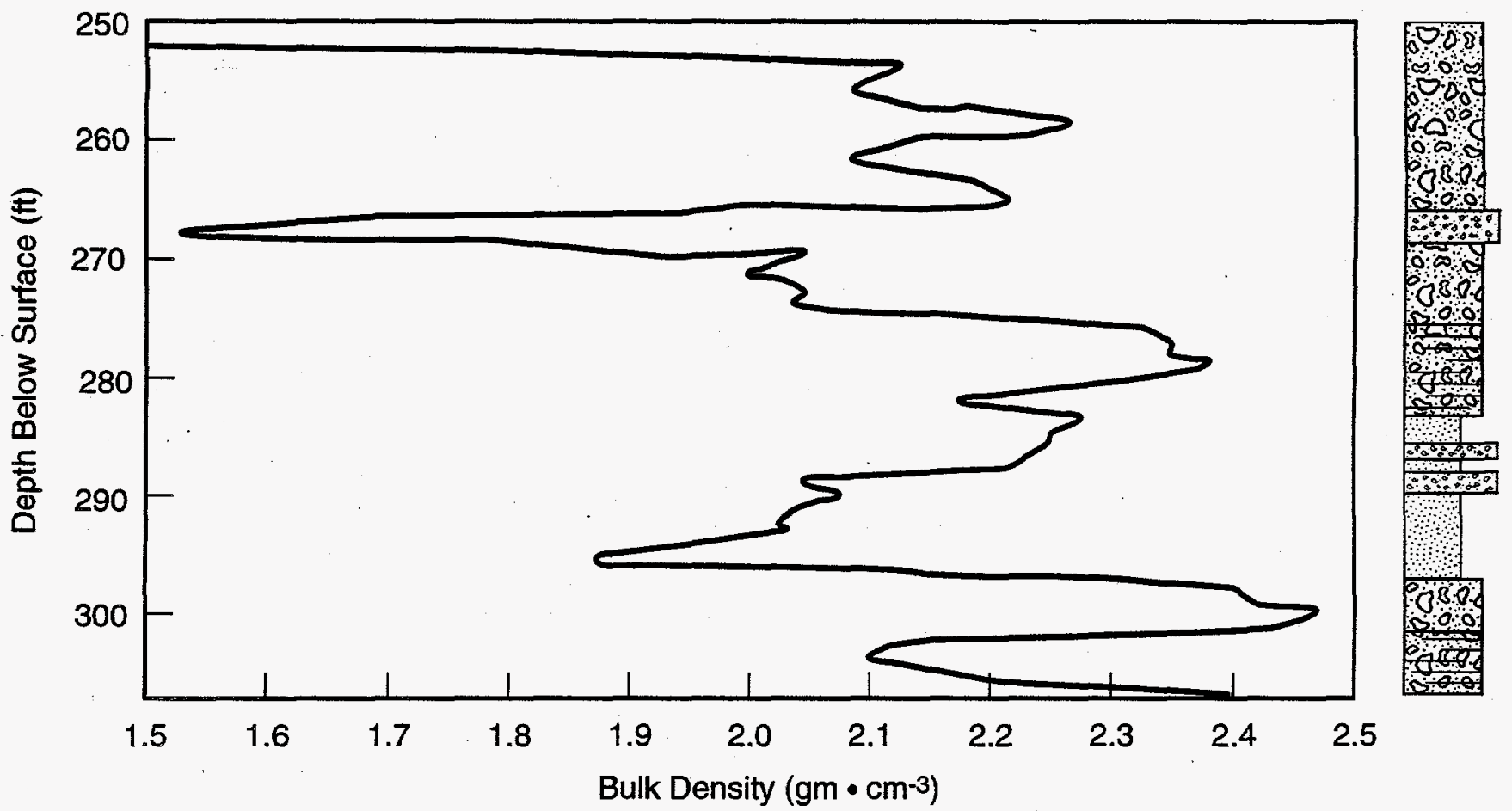

S9412007.2

Figure 4.9. Bulk Density Log of Well 299-W11-32 


\subsection{Hydrologic Characterization}

The purpose of hydrologic characterization is to determine the hydraulic properties of the aquifer, to assure that a hydraulic connection exists between well screens at corresponding depths, and to determine the pumping rates of the well screens. Hydrologic characterization activities included hydraulic tests, ground-water tracer tests, and water-level monitoring. The hydraulic tests discussed include well development, step-drawdown tests, constant-rate pumping tests, and slug displacement tests. Ground-water tracer tests included a series of point-dilution tests, a drift-and-pumpback test, and a natural gradient tracer test.

\subsection{Hydraulic Tests}

Well development, constant-rate pumping tests, and slug displacement tests were conducted at the study site. Well development was conducted by pumping or pumping and surging. Development of well 299-W11-32 included independent development of the three screened intervals. Constant-rate discharge and tracer tests were conducted to estimate hydraulic properties of the aquifer.

\subsubsection{Well Development}

Wells 299-W11-29, 299-W11-30, and 299-W11-32 were developed by pumping following well completion. Wells 299-W11-29 and 299-W11-30 were each developed at approximately $38 \mathrm{~L} / \mathrm{m}$ (10 gpm) for a duration of 100 minutes on May 7, 1992, and May 11, 1992, respectively. For well 299-W11-29, the turbidity of the water decreased from $>100$ Nephelometric Turbidity Units (NTU), near the beginning of pumping, to $15 \mathrm{NTU}$, near the end of pumping. The turbidity of pumped water from well 299-W11-30 decreased from 44 to 5 NTU.

All three screened intervals of well 299-W11-32 were developed simultaneously on October 27 , 1993, by pumping and surging. The discharge rate was approximately $38 \mathrm{~L} / \mathrm{m}$ (10 gpm) over each of three pumping surges, which totaled 166 minutes in duration. The turbidity decreased from visually turbid water, above the range of the meter (i.e., $>100$ NTU), to 12 to $15 \mathrm{NTU}$ at the end of each pumping surge.

During simultaneous development of multiple well screens in a single borehole, it is expected that screen entrance velocity is not evenly distributed between each of the well screens because of the heterogeneous nature of the formation. In this type of well configuration, the pumped water (and resulting turbidity measurement) is representative of that portion of the screen least resistive to flow. Consequently, one or more of the screened intervals may not have been adequately developed. To improve development of each screened interval, each screen was isolated with inflatable packers and developed independently by pumping, as discussed below.

\subsubsection{Well Development of Screens in Well 299-W11-32}

Well development tests were conducted in the isolated screens of well 299-W11-32 between November 10 and 12,1993. The purpose of these tests were to develop each of the screened intervals 
independently and to determine the bentonite seal effectiveness in hydraulically isolating each interval. These tests also provided qualitative information on the yields for each screened interval. Many of the tests were repeated.

The downhole equipment configuration for each test interval is shown in Figures 5.1, 5.2, and 5.3. Each of the screened intervals were isolated using inflatable packers. Pressure responses were measured and recorded with dataloggers and downhole strain-gauge pressure transducers. Flow was measured with an inline flowmeter mounted at the surface and verified manually with a calibrated bucket and stop watch.

The turbidity visually "cleared up" at the beginning of the tests, indicating that most of the finegrained, suspended sediment resulting from drilling was removed during the first few minutes of pumping.

During independent testing of the upper screened interval, a discharge rate of $38 \mathrm{~L} / \mathrm{m}$ (10 gpm) was easily maintained for up to 30 minutes without dewatering the water column. During pumping of the lower screened interval, the water level pressure was lowered to the pump intake in 18 minutes at a flow rate of between 60 and $95 \mathrm{~L} / \mathrm{m}$ (16 and $25 \mathrm{gpm})$.

During independent testing of the middle screened interval, the discharge rate could not be maintained for more than a few minutes without depressurizing the test zone (i.e., lowering the water

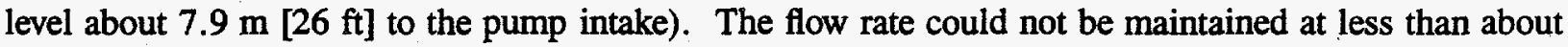
$38 \mathrm{~L} / \mathrm{m}(10 \mathrm{gpm})$ without damaging the pump motor. Because of this difficulty in sustaining flow, one of the packers was deflated, allowing pumping from two screens simultaneously (i.e., pump from the middle and lower screens or pump from the middle and upper screens). These configurations allowed for longer development times and, when coupled with information obtained from independent testing of each screened interval, provided qualitative information on the yields obtainable for each zone. Duration of these tests ranged from 30 to 45 minutes, with flow rates between 38 and $76 \mathrm{~L} / \mathrm{m}(10$ and $20 \mathrm{gpm})$.

During pumping of each screened interval at well 299-W11-32, pressure responses were measured in the nonpumped screened intervals above or below. The pressure response data showed that no pressure changes occurred in these monitored intervals, indicating that the bentonite seal in the annulus, as well as the inflatable packers, effectively provided a seal between the screened intervals. However, these data do not necessarily indicate an impervious vertical zone because it is expected that much longer pumping durations are required to yield pressure responses reflective of the formation vertical permeability.

\subsubsection{Step-Drawdown Tests}

Step-drawdown pumping tests were conducted in wells 299-W11-29 and 299-W11-30, and in the top and bottom screens of well 299-W11-32 to determine estimates of the maximum flow attainable without dewatering (or depressurizing) the test zone. Sufficient flow could not be attained to conduct an ideal step test within the middle screened interval of well 299-W11-32. The maximum flow attainable for each zone will be a factor in designing the final well spacing and completion intervals for the new wells drilled in FY94. Furthermore, sustainable flow rates will determine the size of the biological reaction zone around the well bore used for nutrient injection. 


\section{Pumping from Top Screen}

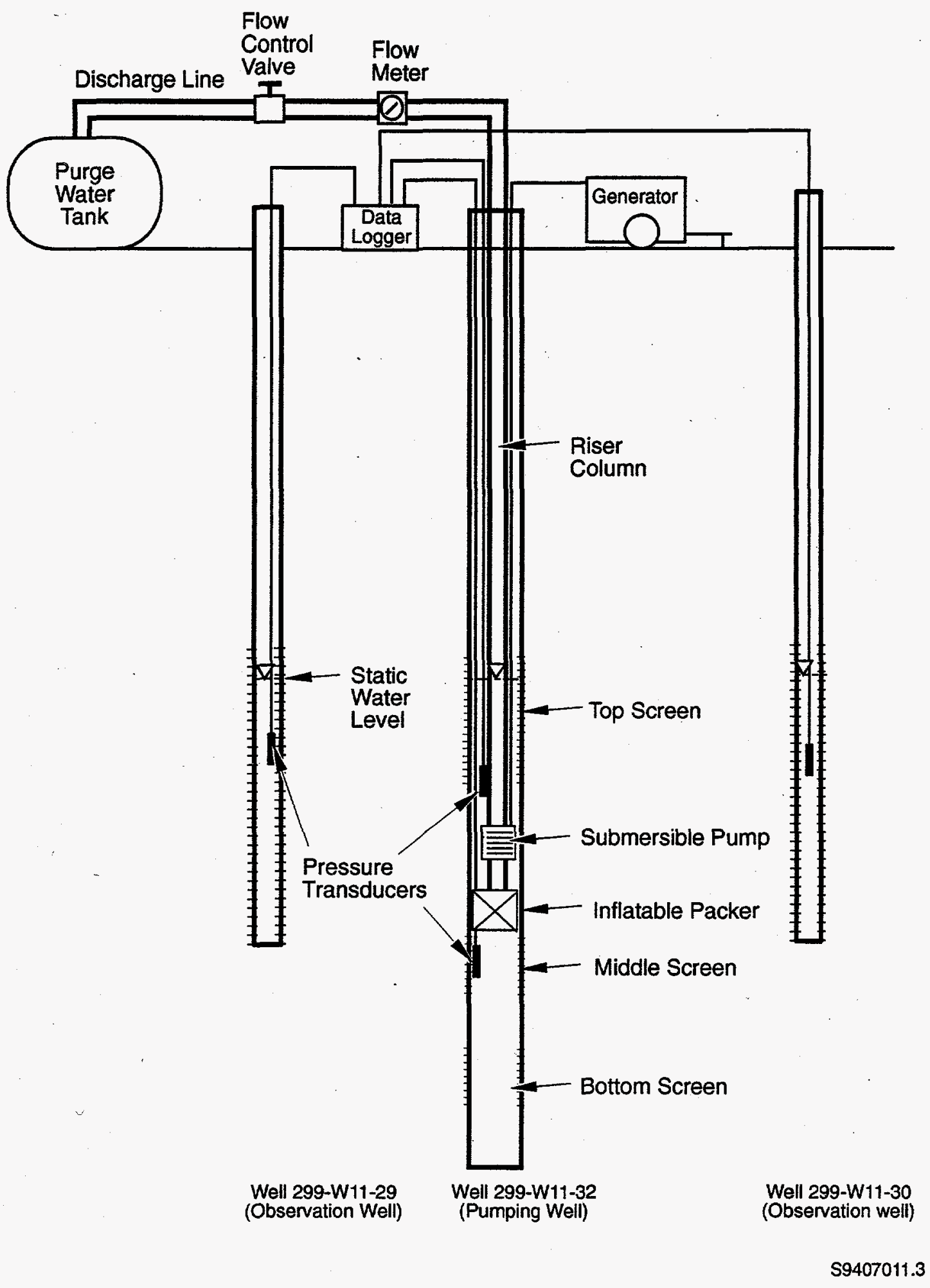

Figure 5.1. Test Configuration for the Upper Screened Interval of Well 299-W11-32 


\section{Pumping from Middle Screen}

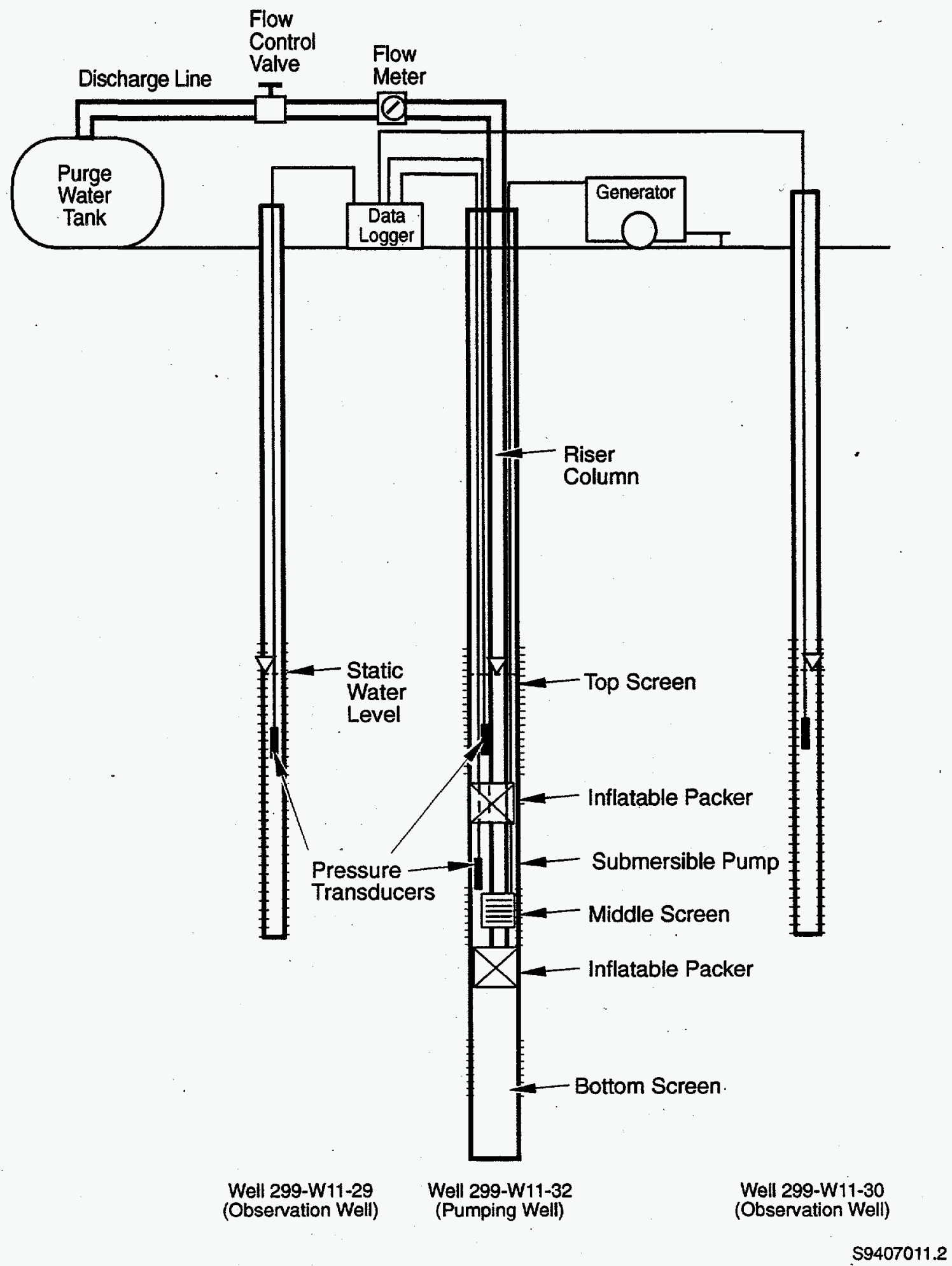

Figure 5.2. Test Configuration for the Middle Screened Interval of Well 299-W11-32 


\section{Pumping from Bottom Screen}

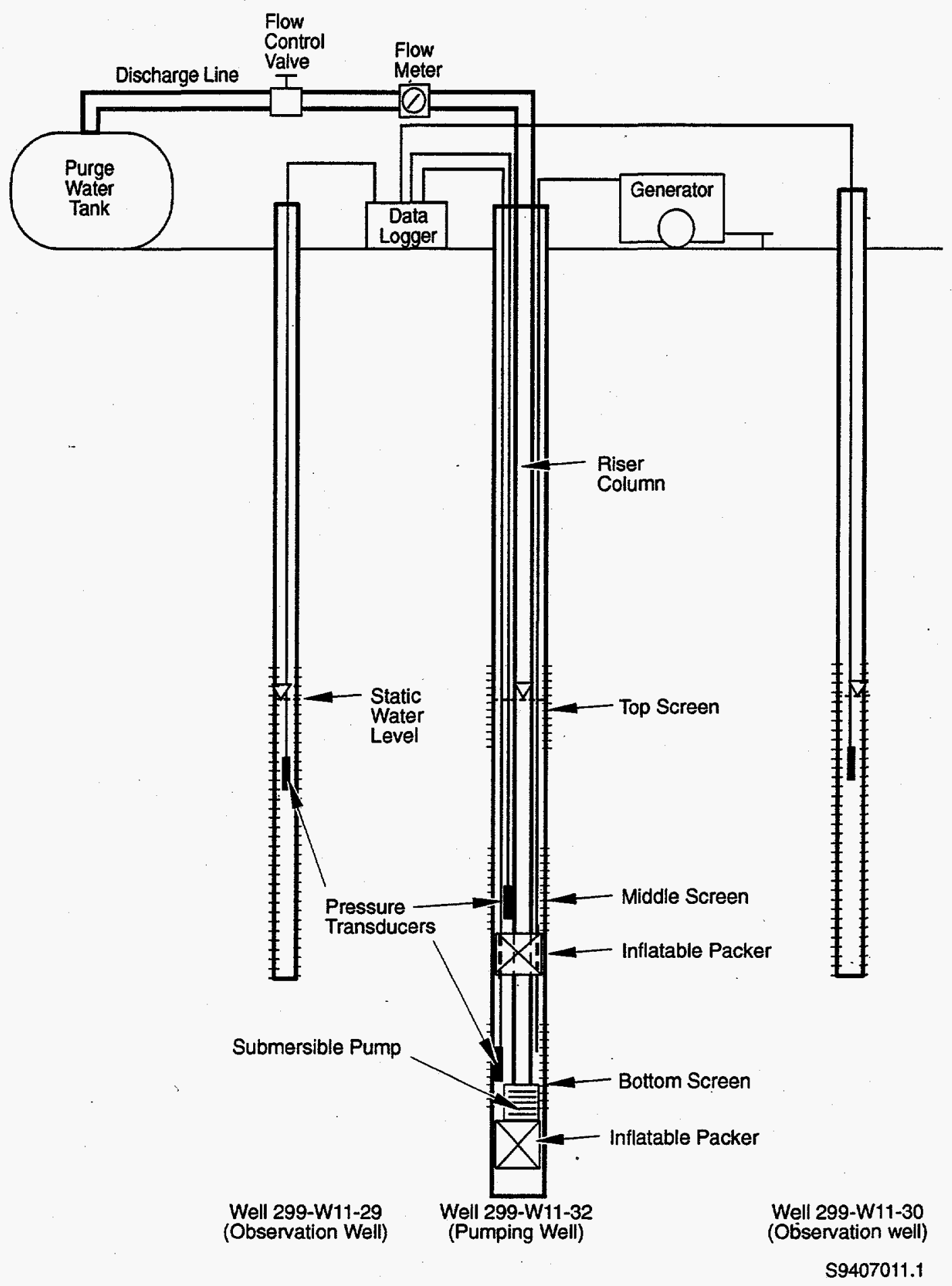

Figure 5.3. Test Configuration for the Bottom Screened Interval of Well 299-W11-32 
Although the durations of the tests were small compared to the duration (i.e., 3 to 9 months) planned for the bioremediation test, it is estimated that most of the pressure response (i.e., roughly $75 \%$ to $90 \%$ of the steady-state pressure response) was attained at the end of each step. Estimates from the step tests provide an indication of the maximum flow rates that could reasonably be expected for long-term extraction.

\section{Well 299-W11-32 (Top Screen)}

A step-drawdown test was conducted in the top screen of well 299-W11-32 on January 24, 1994. The depth of the test interval was 75 to $79 \mathrm{~m}$ ( $247 \mathrm{to} 258 \mathrm{ft}$ ) below land surface. An inflatable packer was placed in the blank casing at a depth of 82 to $84 \mathrm{~m} \mathrm{(269}$ to $274 \mathrm{ft}$ ), just above the middle screen, to isolate the test interval from the middle and bottom screens. The submersible pump intake was located above the packer at a depth of approximately $81 \mathrm{~m}(267 \mathrm{ft})$.

The step-drawdown test was conducted in three 60 -minute flow rate steps of $20.4,38.6$, and $60.6 \mathrm{~L} / \mathrm{m}(5.4,10.2$, and $16.0 \mathrm{gpm})$. A fourth step was attempted at $84.0 \mathrm{~L} / \mathrm{m}(22.2 \mathrm{gpm})$, but flow could not be sustained because the water-level pressure dropped to the level of the pump intake. The total duration of the test was 207 minutes. A semi-log time-drawdown plot, presented in Figure 5.4, shows the maximum drawdown observed for each flow rate step.

\section{Well 299-W11-32 (Bottom Screen)}

A step-drawdown test was conducted in the bottom screen of well 299-W11-32 on January 25, 1994. The depth of the test interval was 89 to $91 \mathrm{~m}$ (293 to $298 \mathrm{ft})$ below land surface. An inflatable packer was placed in the blank casing between the middle and bottom screens to isolate the bottom screen from the two upper screens. The submersible pump intake was located below the inflated packer at a depth of approximately $91 \mathrm{~m}(297 \mathrm{ft})$.

The test was conducted in flow rate steps of $17.0 \mathrm{~L} / \mathrm{m}(4.5 \mathrm{gpm})$ for 60 minutes, $29.5 \mathrm{~L} / \mathrm{m}$ (7.8 gpm) for 140 minutes, $38.6 \mathrm{~L} / \mathrm{m}(10.2 \mathrm{gpm})$ for 40 minutes, and $56.0 \mathrm{~L} / \mathrm{m}(14.8 \mathrm{gpm})$ for about 60 minutes. The total duration of the pumping test was 300 minutes. A constant flow rate could not be easily maintained during the third flow rate step. During the fourth step, flow could not be sustained at $56.0 \mathrm{~L} / \mathrm{m}(14.8 \mathrm{gpm})$ without depressurizing the test zone. A semi-log time-drawdown plot, presented in Figure 5.5, shows the maximum drawdown observed for each flow rate step.

\section{Well 299-W11-29}

A step-drawdown test was conducted in well $299-$ W11-29 on January 28,1994 . The depth of the test interval was from the water table to the bottom of the well at a depth of 75 to $85 \mathrm{~m}$ (247 to $278 \mathrm{ft}$ ). A submersible pump was placed at a depth of about $83 \mathrm{~m}(272 \mathrm{ft})$.

The test was conducted in flow rate steps of $22.0,30.7,38.2,46.9$, and $56.0 \mathrm{~L} / \mathrm{m}(5.8,8.1,10.1$, 12.4 , and $14.8 \mathrm{gpm}$ ). The total duration of the test was 330 minutes. A semi-log time-drawdown plot for the test, presented in Figure 5.6, shows the maximum drawdown observed for each flow rate step. 


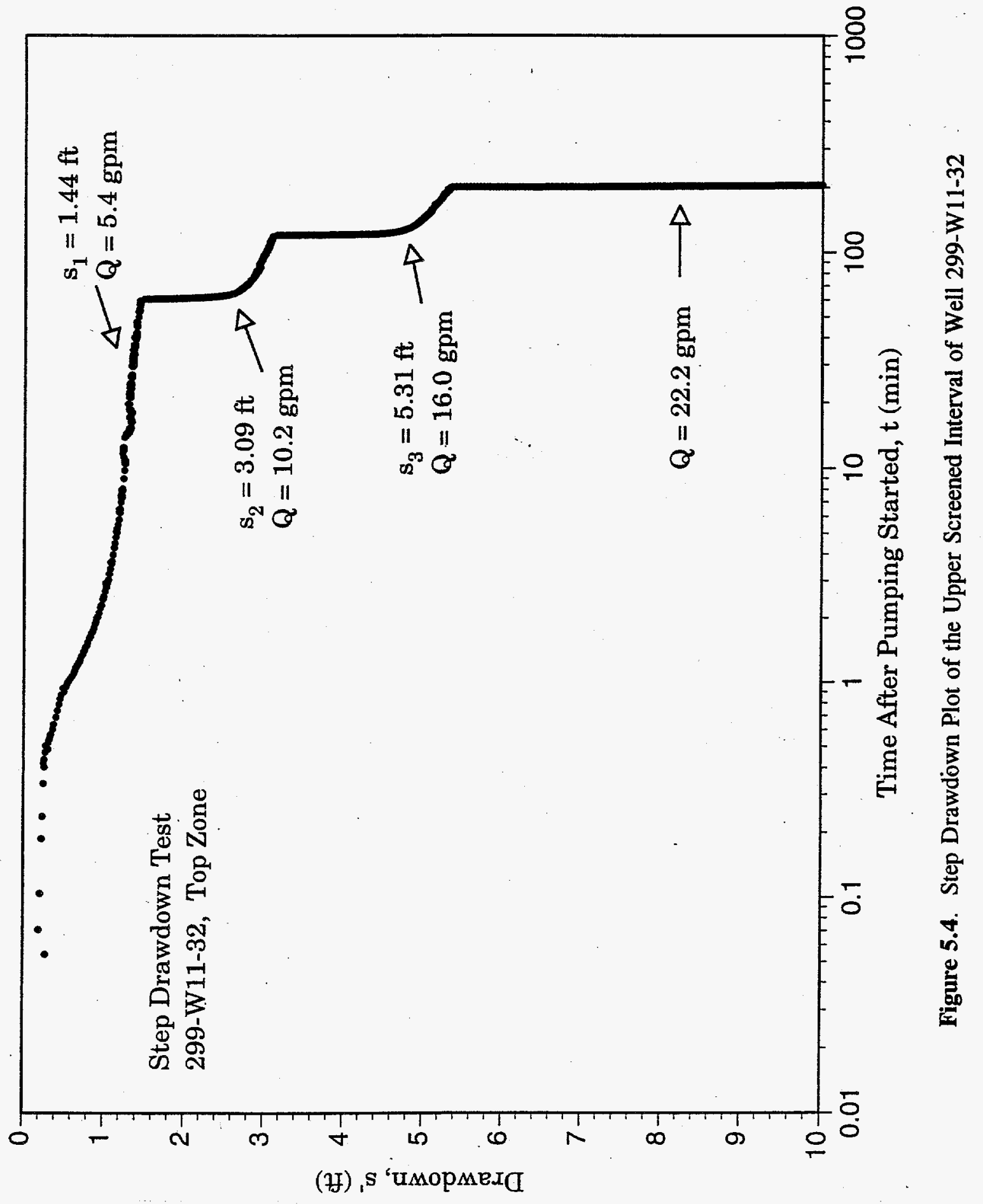




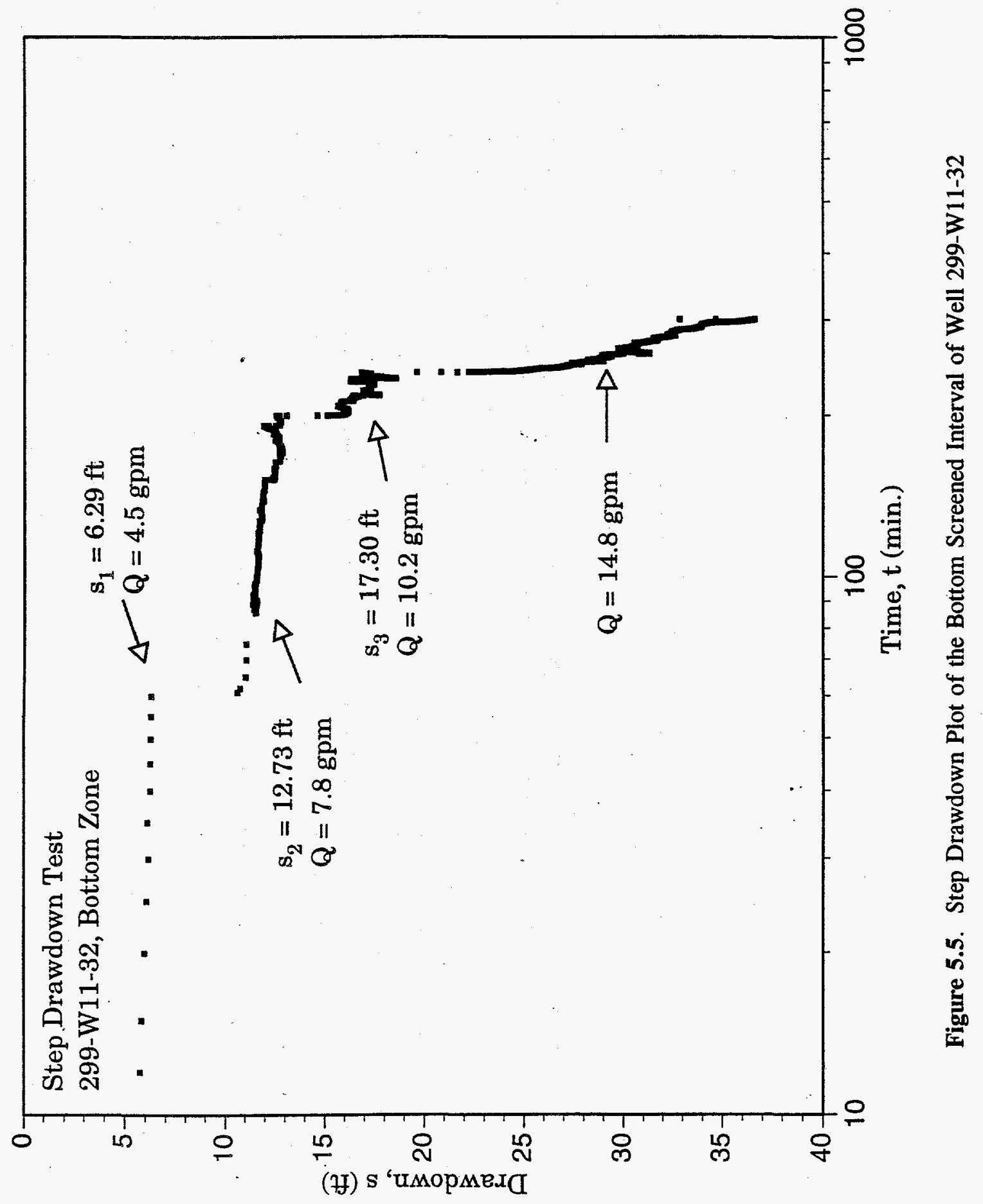




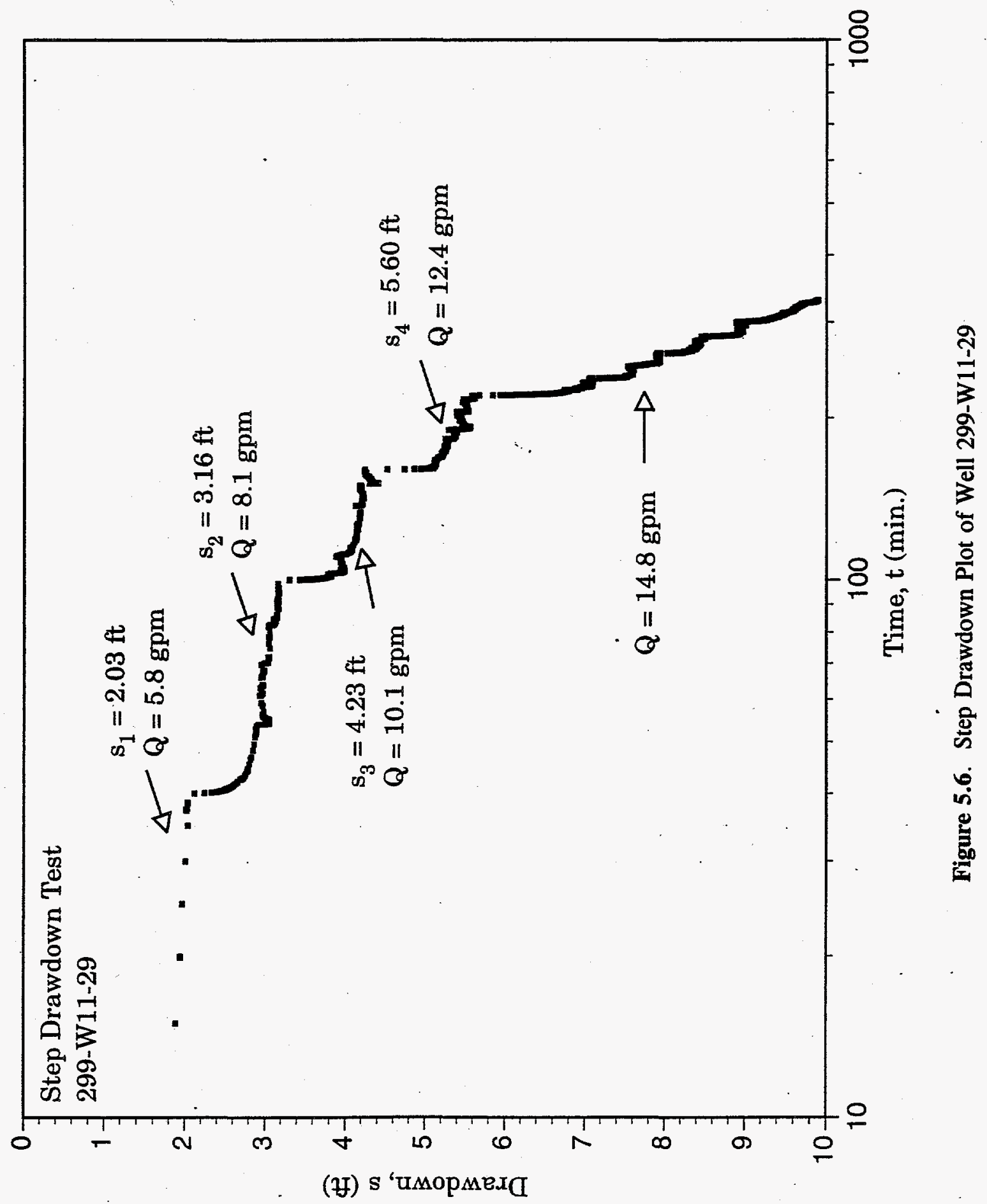


Well 299-W11-30

A step-drawdown test was conducted in well 299-W11-30 on February 1, 1994. The depth of the test interval was from the water table to the bottom of the well at a depth of 75 to $85 \mathrm{~m}$ ( 247 to $279 \mathrm{ft}$ ). A submersible pump was placed at a depth of about $83 \mathrm{~m}(272 \mathrm{ft})$.

The test was conducted in flow rate steps of $20.1,28.4,38,55.6,74.6$, and $117.3 \mathrm{~L} / \mathrm{m}(5.3,7.5$, $10,14.7,19.7$, and $31 \mathrm{gpm}$. The total duration of the test was 330 minutes. A semi-log timedrawdown plot for the test presented in Figure 5.7, shows the maximum drawdown observes for each flow rate step.

\section{Results of Step Drawdown Tests}

The maximum sustainable flow rates estimated from the step drawdown tests are summarized in Table 5.1. These flow rates represent the maximum flow rate that could reasonably be sustained over long-duration extraction for each of the test intervals without causing depressurization or dewatering.

\subsubsection{Constant-Rate Tests}

Four constant-rate pumping tests were conducted in wells 299-W11-30 and 299-W11-32 between 1992 and 1994. A pumping test was conducted in well 299-W11-30 before well 299-W11-32 was drilled and constructed. After well 299-W11-32 was completed, a test was conducted in each of the three screened intervals. The purpose of the tests was to estimate hydraulic properties of the aquifer, including transmissivity $(T)$, hydraulic conductivity $\left(\mathrm{K}_{\mathrm{h}}\right)$, and storage properties.

Inflatable packers were used to isolate the test intervals in well 299-W11-32. Pressurized nitrogen bottles equipped with pressure regulators were used to inflate the packers via inflation lines to the surface. Electric submersible pumps of various sizes (i.e., $0.75 \mathrm{hp}, 3 \mathrm{hp}$, and $5 . \mathrm{hp}$ ) were used to stress the test intervals.

Pressure responses (drawdown and recovery) were measured and recorded with dataloggers and downhole strain-gauge pressure transducers. The pressure data were corrected for fluctuations caused by barometric changes. Flow was measured with an inline flowmeter mounted at the surface and verified manually with a calibrated bucket and stopwatch.

\section{Barometric Efficiency Calculations}

Water levels in wells completed in confined aquifers often respond to barometric pressure changes. These water-level changes are inversely proportional to barometric pressure changes and are related by the barometric efficiency (Jacob 1940). The magnitude of the barometrically induced water-level changes for confined aquifer conditions is a function of the elastic properties of the aquifer, weight (or total stress) of the overlying material, that is, degree of aquifer confinement, and density properties of the fluid. Water levels in wells completed in unconfined aquifers may also respond to barometric pressure changes. However, these changes are also a function of soil gas properties and the thickness and permeability of the overlying vadose zone (Weeks 1979). Unconfined aquifer water-level 


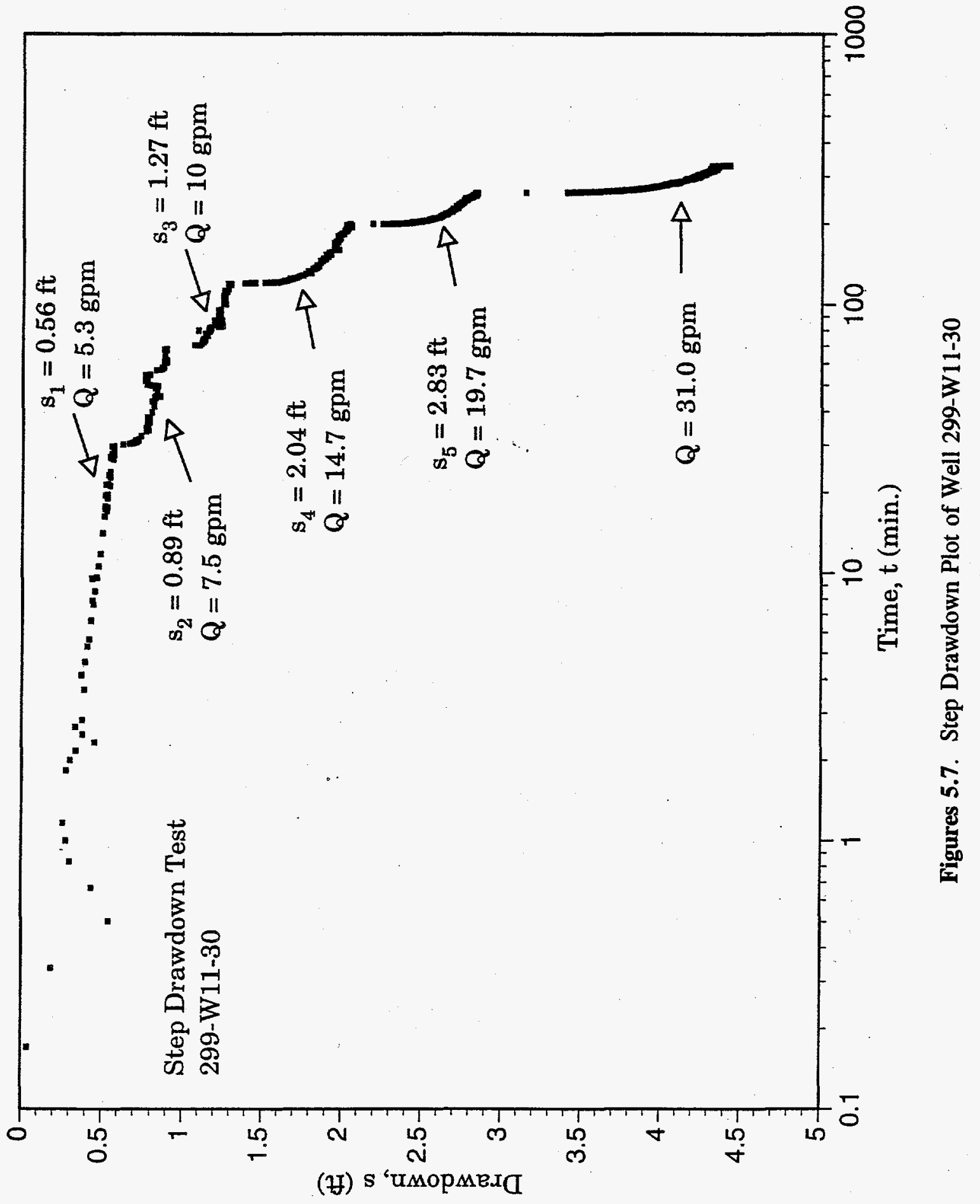


Table 5.1. Sustainable Maximum Flow Rates $\left(Q_{\max }\right)$ Determined from the Step Drawdown Tests

\begin{tabular}{lcc}
\multicolumn{1}{c}{ Well Number } & $\begin{array}{c}\text { Length of Test } \\
\text { Interval }(\mathbf{m})\end{array}$ & $\begin{array}{c}\mathbf{Q}_{\max } \\
(\mathbf{L} / \mathbf{m})\end{array}$ \\
\cline { 2 - 3 } 29 & 9.4 & 38 \\
30 & 9.4 & 95 \\
32 (Top Screen) & 3.4 & 38 \\
32 (Middle Screen) & 1.5 & $<2.5$ \\
32 (Bottom Screen) & 1.5 & 38
\end{tabular}

responses to atmospheric pressure changes are also dependent on the elastic and fluid flow properties of the aquifer, thickness of the open interval, and on the frequency of the atmospheric pressure changes (Rojstaczer and Riley 1990).

Barometric pressure changes affected the constant-rate test responses monitored during pumping and recovery. For the purpose of removing these external effects, baseline water-level (and corresponding atmospheric pressure) data were collected before or after performing the test to calculate barometric efficiency of each monitored location. A method described in Clark (1967) was used to calculate the barometric efficiencies. These determined values were then used to correct the test response data by removing the portion of the test pressure responses attributed to barometric pressure changes that occurred during the test. The methodology used for removing barometric effects from constant-rate pumping test data is similar to that described in more detail in Spane (1993).

Baseline water-level monitoring data were collected from wells 299-W11-29 and 299-W11-30 between May 13 and 20, 1992, and from wells 299-W11-29, 299-W11-30, and 299-W11-32 between November 19, 1993, and December 16, 1993. The frequency of measurement was 1 hour. Atmospheric pressure data were also collected at 1-hour intervals, covering approximately the same periods. These data were collected from the Hanford Meteorological Station, located east of the 200-West Area. The instrumented downhole configuration for each monitoring location is illustrated in Figure 5.2. Water-level pressures were measured with Druck and Keller strain-gage pressure transducers and recorded with Campbell Scientific, Inc., data loggers.

Figure 5.8 shows a comparison of the water-level data and corresponding barometric pressure changes during baseline monitoring of the top screened interval of well 299-W11-32. Figure 5.8 also shows the corrected water-level pressure with atmospheric pressure effects removed, based on a barometric efficiency value of 0.70 . The variations in the corrected water-level pressures are caused by incomplete removal of barometric effects and by other external stresses, including changes in artificial recharge to the ground-water system at 200-West Area and Earth tides. High frequency monitoring of both effluent releases and water-level pressures over extended periods of time would be required to establish correlative relationships with these external stresses, which is outside the scope of this report. However, the effects of Earth tides are expected to be small and were not corrected for. Several papers in the literature indicate that wells respond to Earth tides on a diurnal frequency cycle (Weeks 1979; Rojstaczer and Agnew 1989; Rojstaczer and Riley 1990). 


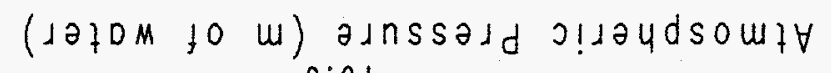
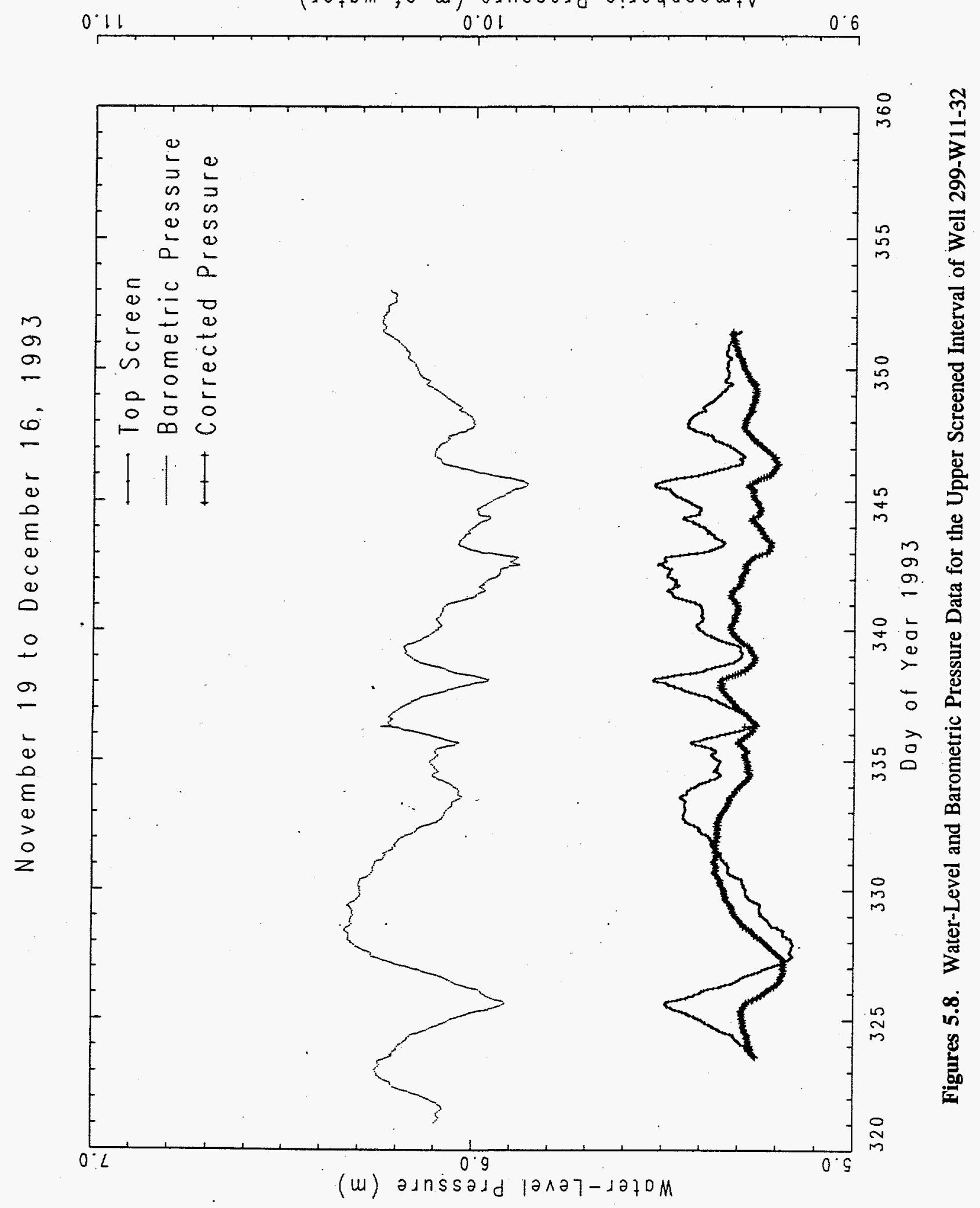
Part of the data record (i.e., day 335 to 350 ) shows that the shape of the corrected water-level pressure plot is similar to that for the uncorrected pressure plot. This indicates that barometric pressure effects may not have been completely removed because of errors associated with time lag and nonlinearity of the water-level response. The barometric efficiency is calculated from a best-fit straight line through a plot of the sum of water-level pressure change versus the sum of barometric pressure change. The effects of time lag associated with atmospheric pressure-induced water-level changes were not corrected because the time shift is not discernable, based on an hourly measurement frequency.

Similar barometrically induced water-level pressure responses were observed in each of the other monitoring well locations. A summary of the barometric efficiency results, including correlation coefficient, for each monitored location are tabulated in Table 5.2. Table 5.2 shows that barometric efficiencies were consistent at all monitoring well locations, not varying more than a few percent.

\section{Well 299-W11-30 Test Results}

A 10-hour constant-rate pumping test was conducted at well 299-W11-30 on May 21, 1992. The depth of the 9-m (31-ft) test interval is approximately 75 to $85 \mathrm{~m}(247$ to $278 \mathrm{ft})$ for each well. The intake of the submersible pump was placed at a depth of $85 \mathrm{~m}(279 \mathrm{ft})$. The discharge rate was controlled with a flow control valve at the surface. The flow rate was measured periodically by measuring the time required to fill a known volume (i.e., $19 \mathrm{~L}$ [5-gal] bucket). The average discharge rate at well $299-\mathrm{W} 11-30$ was $43.5 \mathrm{~L} / \mathrm{m}(11.5 \mathrm{gpm})$. All pumped water was discharged to tanker trucks, which transported the water to a disposal facility.

Drawdown and recovery data were collected from the stressed well (299-W11-30) and observation well 299-W11-29. Based on the vertical deviation surveys of the two wells (see Tables 3.2 and 3.3), the average distance between the screens over the test intervals is approximately $6.9 \mathrm{~m}(22.7 \mathrm{ft})$. See Figure 3.3 for the plan view of the wells. The maximum drawdown observed was $0.5 \mathrm{~m}(1.7 \mathrm{ft})$ for the stress well and $0.4 \mathrm{~m}(1.2 \mathrm{ft})$ for the observation well. Pressure responses were measured with Druck strain-gage pressure transducers and recorded with a Campbell Scientific, Inc., data logger.

Table 5.2. Barometric Efficiency Results for the Monitoring Well Locations

\begin{tabular}{|c|c|c|}
\hline $\begin{array}{c}\text { Monitoring } \\
\text { Well Location }\end{array}$ & $\begin{array}{c}\text { Barometric } \\
\text { Efficiency (\%) }\end{array}$ & $\begin{array}{l}\text { Correlation } \\
\text { Coefficient }\end{array}$ \\
\hline \multicolumn{3}{|l|}{ May 1992} \\
\hline $299-W 11-29$ & 76 & 0.9990 \\
\hline 299-W11-30 & 70 & 0.9993 \\
\hline \multicolumn{3}{|l|}{ November 1993} \\
\hline 299-W-11-29 & 72 & 0.9993 \\
\hline 299-W-11-30 & 72 & 0.9994 \\
\hline 299-W-11-32 (Top) & 70 & 0.9990 \\
\hline 299-W-11-32 (Middle) & 74 & 0.9990 \\
\hline 299-W-11-32 (Bottom) & 73 & 0.9994 \\
\hline
\end{tabular}


The analysis assumed that the wells fully penetrate the aquifer $9 \mathrm{~m}(31 \mathrm{ft})$ (i.e., the bottom of the test interval is the bottom of the aquifer). This assumption is based on the lower permeability observed from hydraulic tests conducted in the middle screened interval and on the expected low vertical permeability of the formation as a result of horizontal bedding and lamination. The analysis also assumed an unconfined aquifer with delayed gravity effects with a specific yield of 0.1 . Because of well losses associated with the stressed well, the best estimates of transmissivity are those from the observation well.

Figure 5.9 shows a diagnostic log-log plot of drawdown and drawdown derivative. The derivative plot indicates Theisian behavior between about 20 and 100 minutes, with delayed gravity affecting the pressure responses after approximately 100 minutes of pumping. The derivative calculation method and associated diagnostic techniques are described in Spane and Wurstner (1993). A Cooper and Jacob (1946) semi-log straight line analysis was applied to the test data for time between 20 and 100 minutes, which is indicative of radial flow conditions within the formation. Figure 5.10 shows the straight line plot and results of the analysis. From the slope of a best-fit line through the data for $20<$ time $<100$ minutes, transmissivity was estimated to be $69 \mathrm{~m}^{2} / \mathrm{d}\left(740 \mathrm{ft}^{2} / \mathrm{d}\right)$ and storativity was estimated to be 0.004 . Figure 5.10 also shows the effects of delayed gravity response after 100 minutes, as displayed by a second straight line with a reduced slope.

Based on transmissivity and storativity (s) estimates obtained from the straight line analysis, type curve and derivative type curve matches of the log-log data were generated. The DELAY2 program, adopted by Neuman (1975), was used to generate the type curve for the drawdown data. These type curve plots overlay the data plots in Figure 5.9. The analysis of pressure response data from observation well 299-W11-29 yielded estimates for transmissivity of $68 \mathrm{~m}^{2} / \mathrm{d}\left(730 \mathrm{ft}^{2} / \mathrm{d}\right)$ and for storativity of 0.004 . The transmissivity divided by the test interval thickness of $9 \mathrm{~m}(31 \mathrm{ft})$ yields an estimate for equivalent hydraulic conductivity of approximately $7 \mathrm{~m} / \mathrm{d}(24 \mathrm{ft} / \mathrm{d})$.

A full penetration analysis was also applied to the recovery data for the observation well. Typecurve matching analysis of log-log plots, shown in Figure 5.11, yielded as estimate for transmissivity of $68 \mathrm{~m}^{2} / \mathrm{d}\left(730 \mathrm{ft}^{2} / \mathrm{d}\right)$, and for storativity of 0.004 , which is consistent with analysis results obtained for the drawdown data.

\section{Well 299-W11-32 (Top Screen) Test Results}

A 12-hour pumping test was conducted in the upper screened interval of well 299-W11-32 on November 16, 1993. The test interval was open to the upper $3 \mathrm{~m}(11 \mathrm{ft})$ of the aquifer between a depth

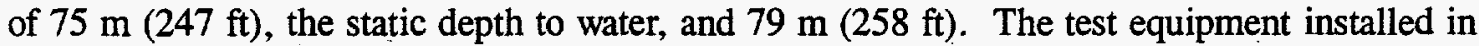
well 299-W11-32 is shown in Figure 5.1. An inflatable packer was placed in the blank casing at a depth of 82 to $84 \mathrm{~m}$ ( 269 to $274 \mathrm{ft}$ ), sealed just above the middle screen, to isolate the test interval from the middle and bottom screens. The submersible pump intake was located above the packer at a depth of approximately $81 \mathrm{~m}(267 \mathrm{ft})$. The discharge rate was controlled with a flow control valve at the surface and monitored continuously with a Signet Scientific Company paddlewheel-type flowmeter. The continuous flow rate measurements were periodically verified by measuring the time required to fill a known volume (i.e., 19-L [5-gal] bucket). The average flow rate at the stressed well was measured to be approximately $45 \mathrm{~L} / \mathrm{m}(12 \mathrm{gpm})$. All pumped water was discharged to a purge water tank. 


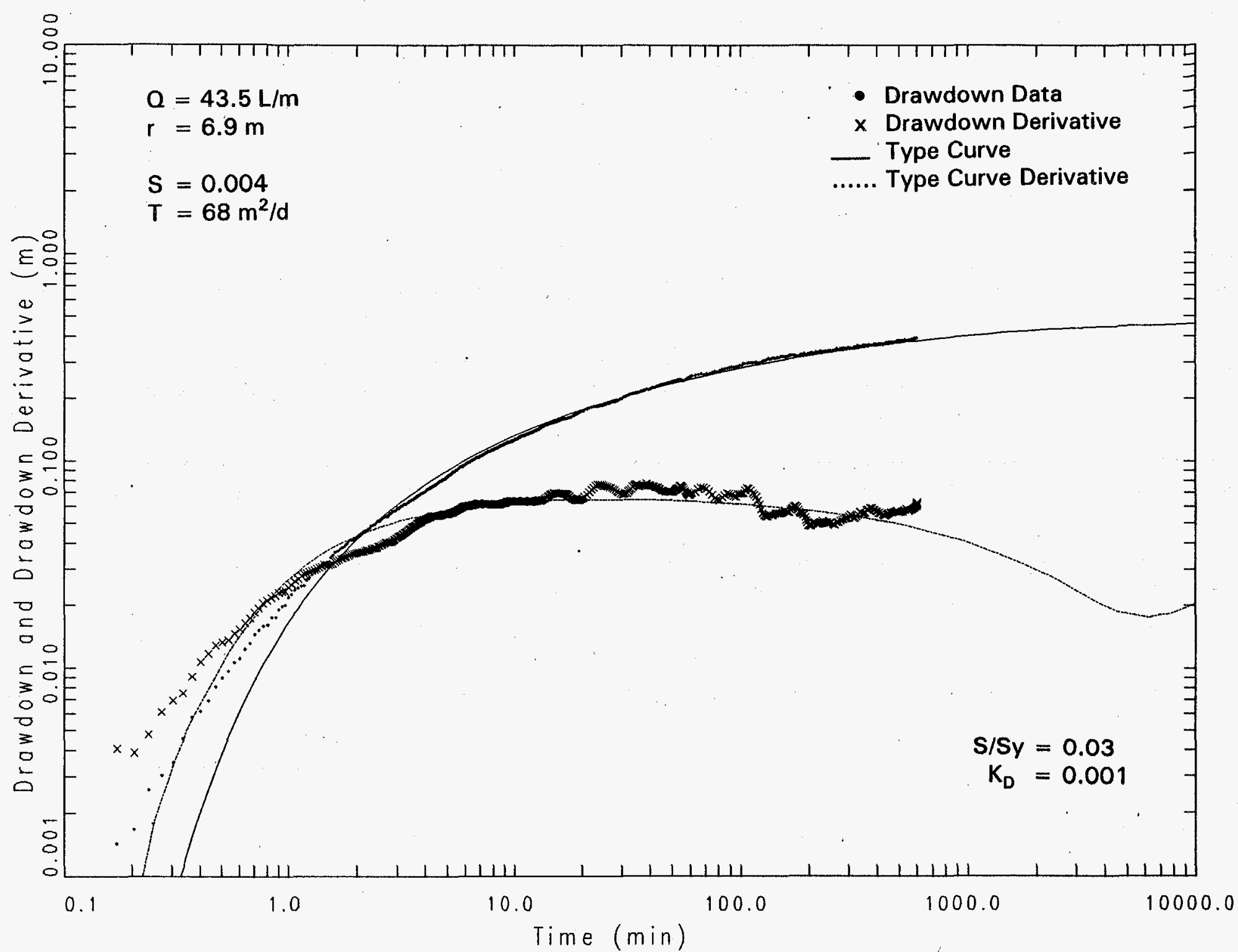

Figure 5.9. Type-Curve Drawdown Data Analysis for Well 299-W11-29 


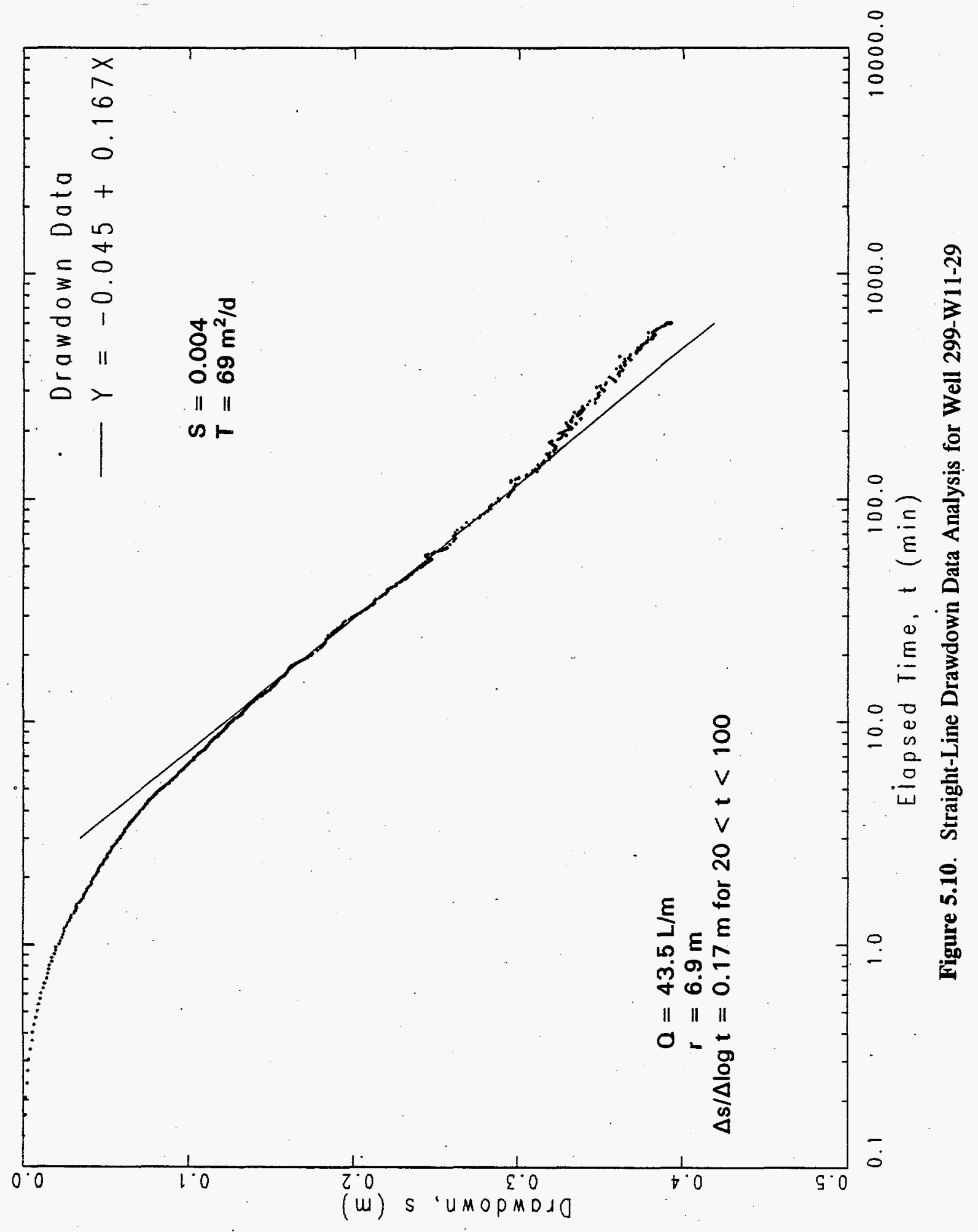




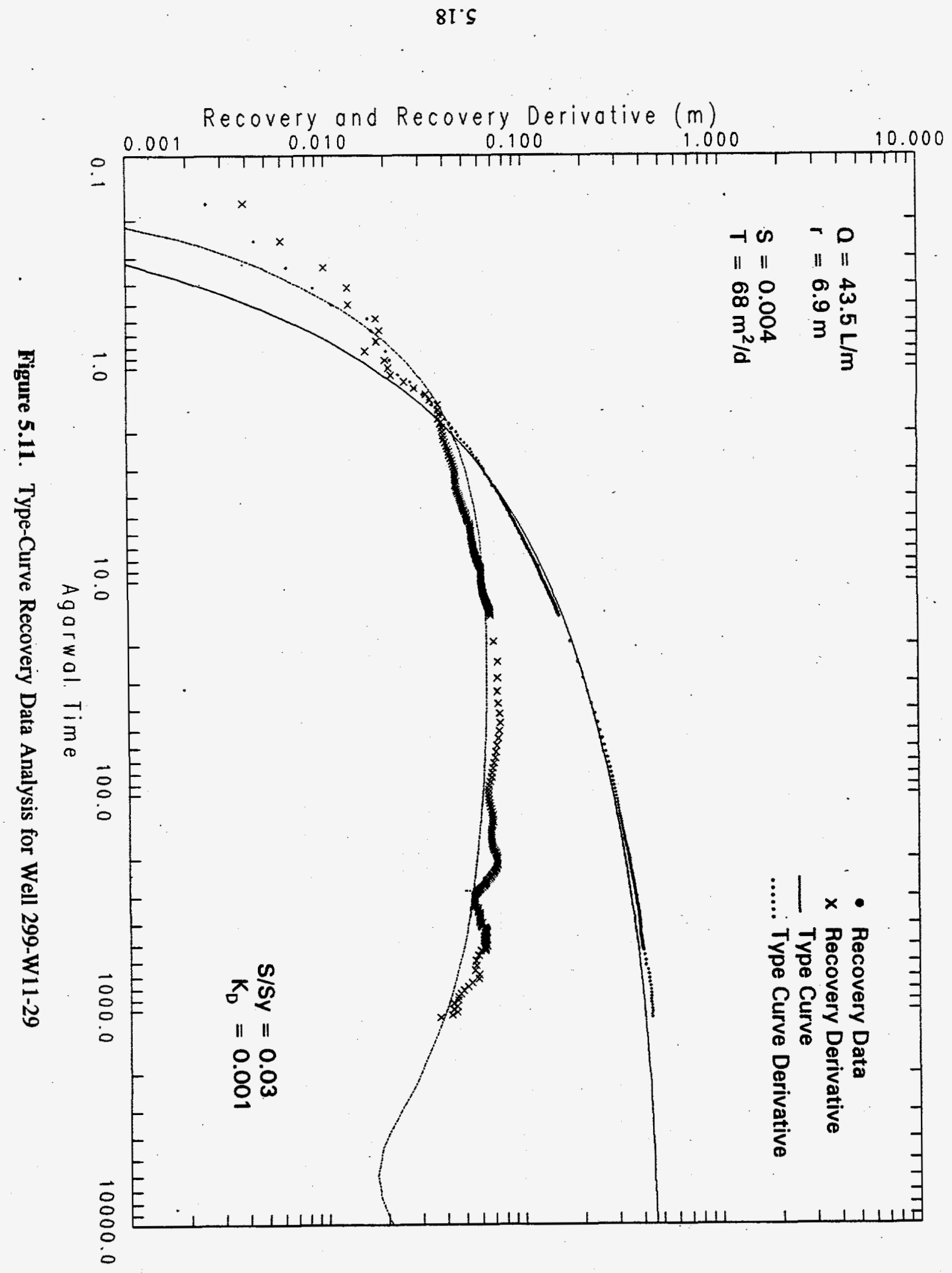


Drawdown and recovery data were collected from the test interval of well 299-W11-32 and from observation wells 299-W11-29 and 299-W11-30. The maximum drawdown observed was $0.5 \mathrm{~m}$ $(1.6 \mathrm{ft})$ in wells $299-\mathrm{W} 11-29$ and $299-\mathrm{W} 11-30$ and $1.6 \mathrm{~m}(5.1 \mathrm{ft})$ in the stressed interval. Pressure responses were also monitored in the two lower screens of well 299-W11-32, below the inflatable packer, to ensure that the inflatable packers and the seal in the annular space between the screens provided an adequate seal. Pressure responses were measured with Keller strain-gage pressure transducers and recorded with a Campbell Scientific, Inc., data logger.

Based on the vertical deviation surveys, the screened intervals of wells 299-W11-29 and 299-W11-30 are located approximately 3.8 and $5.2 \mathrm{~m}$ (12.6 and $17.0 \mathrm{ft})$, respectively, from the stressed interval (top screen) of well 299-W11-32. See Figure 3.3 for the plan view of the wells.

The recovery data for observation wells 299-W11-29 and 299-W11-30 yielded the best estimates of transmissivity and specific yield, and therefore were analyzed and are presented here. The analysis assumed that the observation wells fully penetrate the aquifer (i.e., negligible vertical leakage). This can be reasonably assumed because the point-dilution tracer test results (discussed later in Section 5.2)

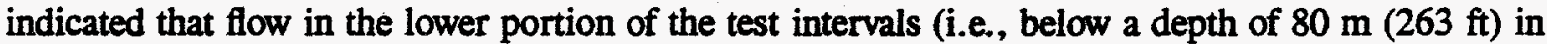
well 299-W11-30 and below a depth of $80 \mathrm{~m}$ (272 ft) in well 299-W11-29) was less than 0.1 relative to flow in the upper part of the test intervals. Therefore, it is assumed that horizontal flow (i.e., radial flow) was dominant during the pumping test.

Drawdown data for the stressed well (top screen of well 299-W11-32) were not analyzed because of uncertainties associated with analyzing nonformational pressure responses common to constant-rate pumping tests, including well inefficiencies and wellbore storage effects (Spane 1993).

Log-log plots of recovery data and recovery derivative versus the Agarwal equivalent time function $\left(t_{e}\right)$ (Agarwal 1980), for the two observation wells are shown in Figures 5.12 and 5.13. The flattening out of the derivative curve indicates that radial flow conditions were established for $t_{e}$ greater than about 10. The derivative calculation method and associated diagnostic techniques are described in Spane and Wurstner (1993).

The Cooper and Jacob (1946) semi-log straight-line analysis method was applied to the recovery data, as shown in Figures 5.14 and 5.15. Application of this method to recovery data requires conversion of the time parameter to that described in Agarwal (1980) because the Cooper and Jacob method was developed for drawdown data analysis. The Agarwal time parameter accounts for the duration of pumping preceding recovery, thereby yielding recovery responses equivalent to the drawdown curve.

To satisfy the analytical assumption that $u \leq 0.01$, as described in Lohman (1972), the straightline solution was applied to the data for $t_{e}>90$ for each well. For well 299-W11-29, the straight-line method yielded a value of $68 \mathrm{~m}^{2} / \mathrm{d}\left(730 \mathrm{ft}^{2} / \mathrm{d}\right)$ for transmissivity and a value of 0.012 for specific yield. For well 299-W11-30, transmissivity was estimated to be $68 \mathrm{~m}^{2} / \mathrm{d}\left(730 \mathrm{ft}^{2} / \mathrm{d}\right)$ and specific yield was 0.006 .

It is evident from the diagnostic $\log -\log$ plots that the pressure responses behaved similarly to confined aquifer pressure responses. (i.e., Theisian behavior). The delayed yield phenomena, commonly characteristic of unconfined aquifer response behavior, was negligible over the duration of 


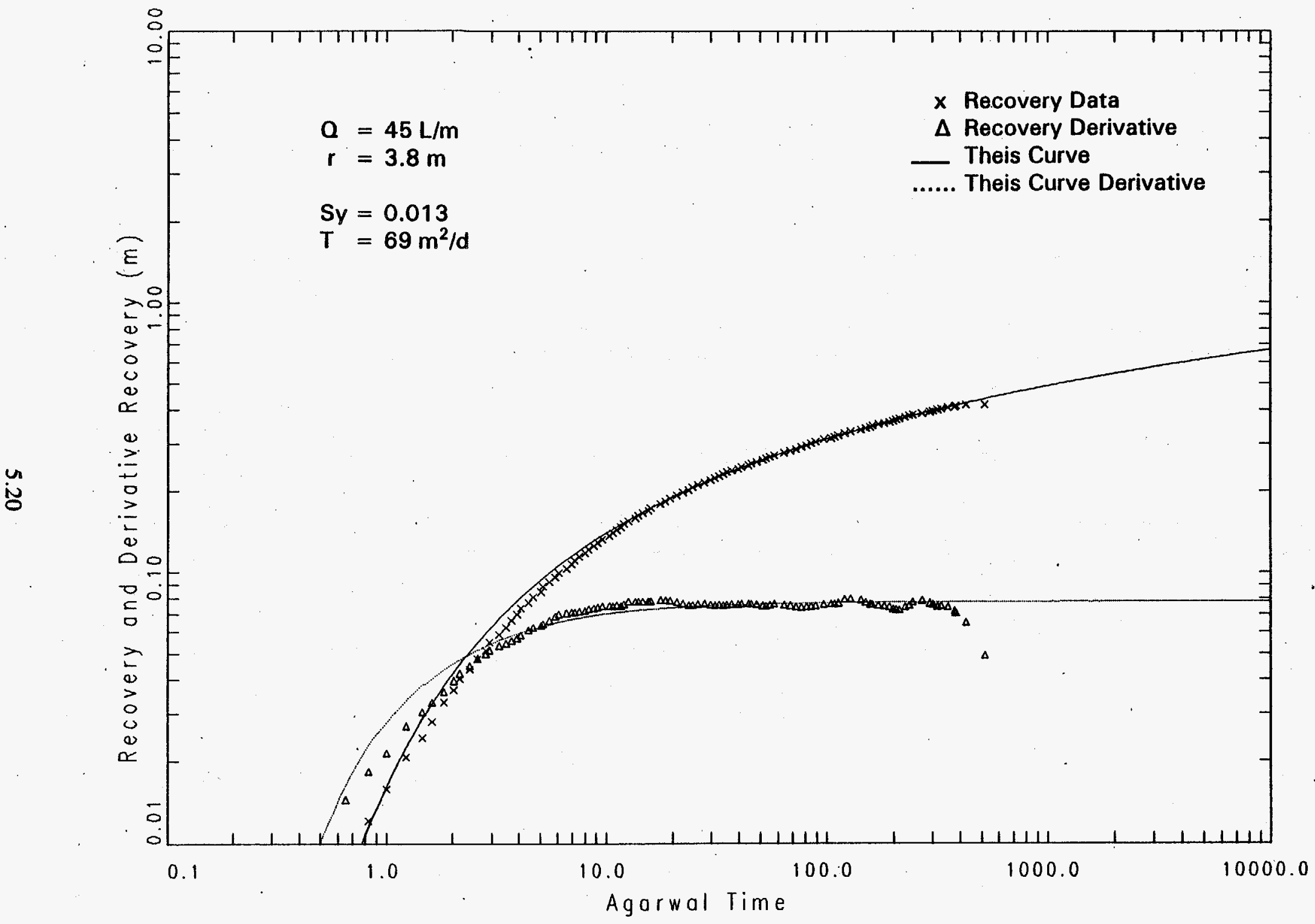

Figure 5.12. Type-Curve Recovery Data Analysis for Well 299-W11-29 


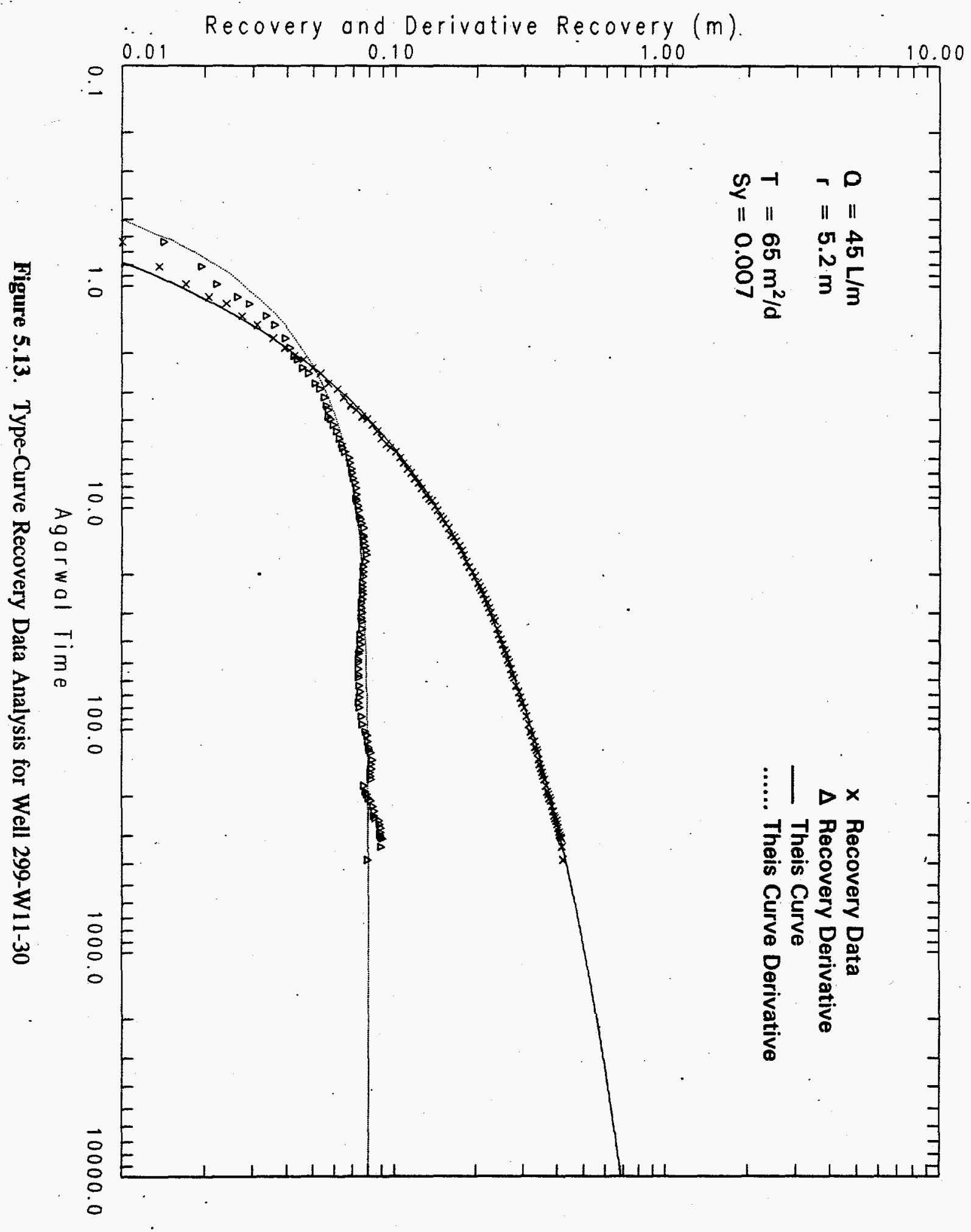




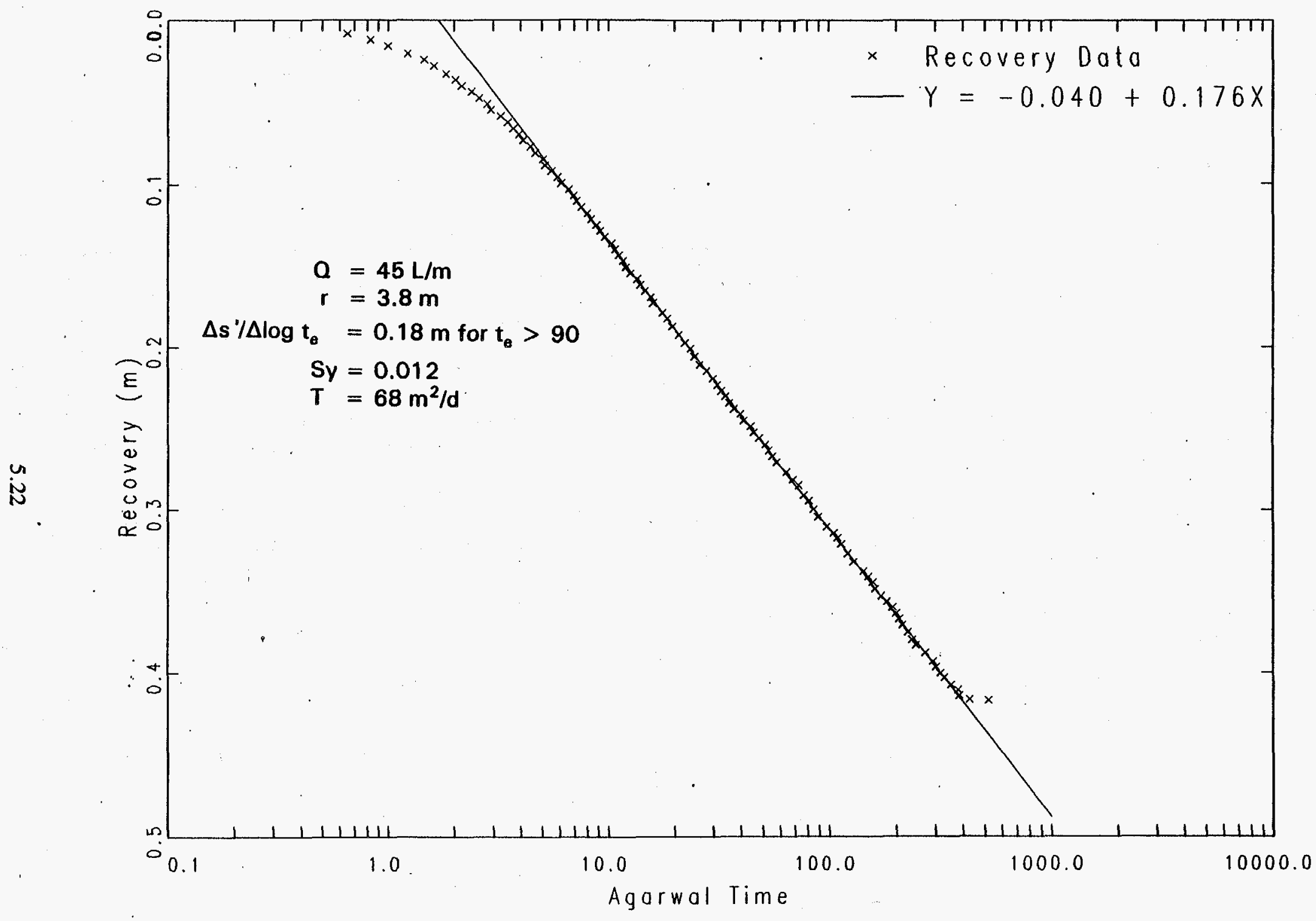

Figure 5.14. Straight-Line Recovery Data Analysis for Well 299-W11-29 


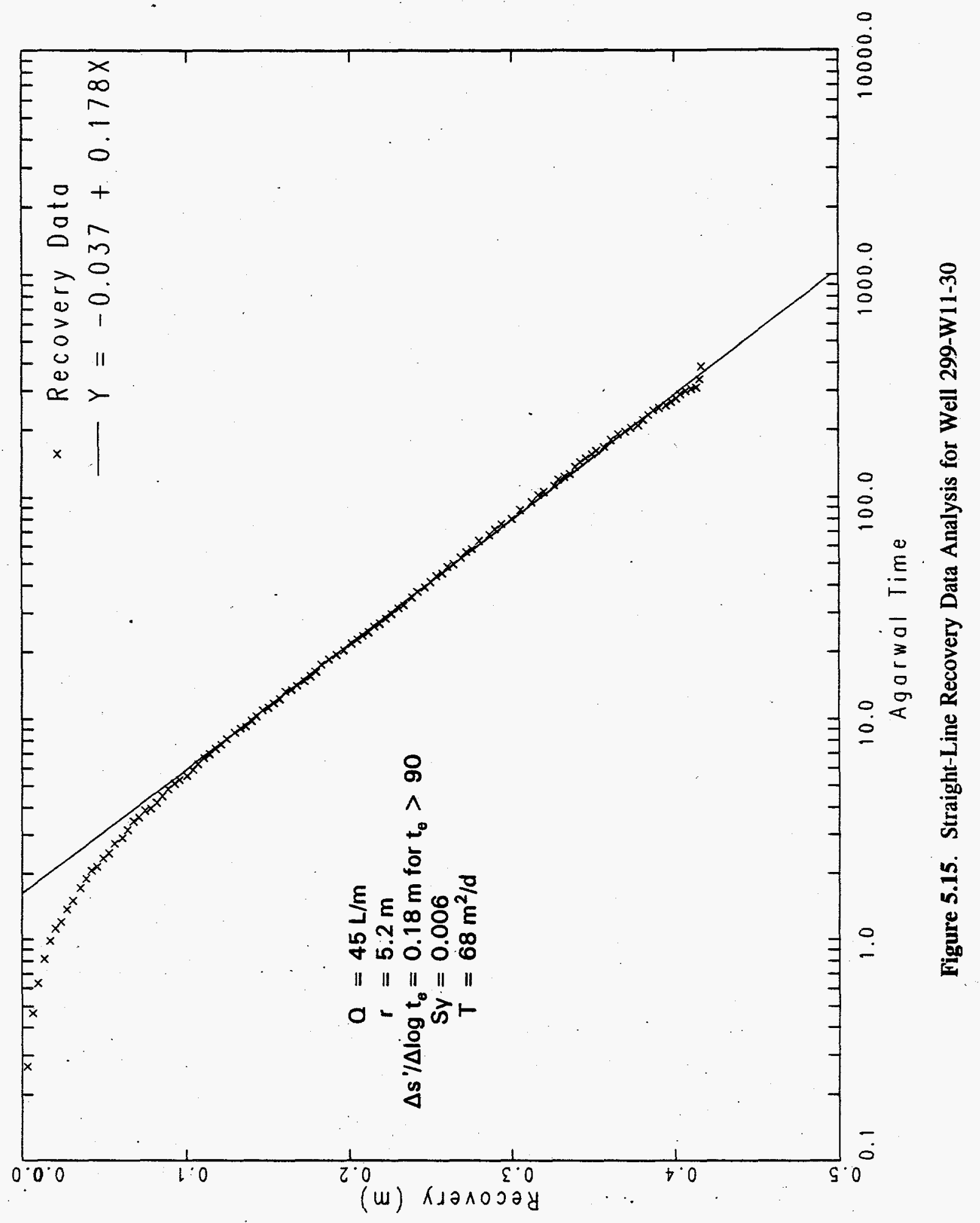


this test. This lack of the delayed yield response is consistent with the low values estimated for specific yield and indicates low vertical permeability in the upper part of the aquifer.

For additional analysis, the recovery and derivative of recovery plots for each well were simultaneously matched to the Theis curve, $W(u)$ versus $1 / u$, and derivative of $W(u)$ versus $1 / u$. In Figures 5.12 and 5.13, the Theis (and derivative) curves were calculated for each corresponding equivalent recovery and derivative recovery plots using the equations described in Lohman (1972).

A simultaneous best-fit match for well 299-W11-29 yielded $67 \mathrm{~m}^{2} / \mathrm{d}\left(720 \mathrm{ft}^{2} / \mathrm{d}\right)$ for transmissivity and 0.013 for specific yield. The best-fit match for well 299-W11-30 resulted in a transmissivity value of $65 \mathrm{~m}^{2} / \mathrm{d}\left(700 \mathrm{ft}^{2} / \mathrm{d}\right)$ and specific yield value of 0.007 . A summary of the test results for the straightline and type-curve matching techniques are shown in Table 5.3.

\section{Well 299-W11-32 (Middle Screen) Test.Results}

A constant-rate pumping test was conducted in the middle screened interval of well 299-W11-32 on January 17, 1994. The test interval was at a depth of 83 to $85 \mathrm{~m}(273$ to $278 \mathrm{ft}$ ), 8 to $9 \mathrm{~m} \mathrm{(26} \mathrm{to} 31 \mathrm{ft}$ ) below the water table. Inflatable packers were placed in the blank casing above and below the middle screen to isolate the test interval from the top and bottom screens. The submersible pump intake was

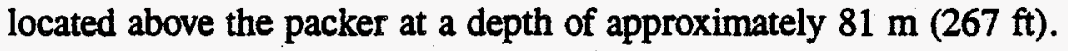

The flow rate ranged between 2.3 and $2.6 \mathrm{~L} / \mathrm{m}(0.61$ and $0.69 \mathrm{gpm})$, averaging about $2.5 \mathrm{~L} / \mathrm{m}$ $(0.67 \mathrm{gpm})$. The test had to be stopped after 6 hours of pumping because the pressure response decreased to the level of the pressure transducer. A constant flow rate was difficult to maintain during the test because of the high sensitivity between pressure response and flow.

Drawdown pressure responses were monitored in all three screened intervals of well 299-W11-32 and in wells 299-W11-29 and 299-W11-30. The maximum pressure response observed in the test interval was $4.1 \mathrm{~m}(13.5 \mathrm{ft})$. Pressures in the top and bottom screens and in the two observation wells did not respond during pumping. During recovery, the check valve leaked, causing water in the discharge line to flow back into the formation, masking the recovery response. Therefore, the recovery data from the test interval are not analyzable.

Table 5.3. Hydraulic Properties Estimated Using Straight-Line and Type-Curve Matching Techniques

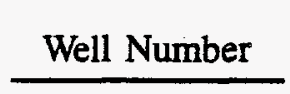

299-W11-29

299-W11-30

$\frac{\text { Straight-Line Method }}{\mathrm{T}\left(\mathrm{m}^{2} / \mathrm{d}\right)}$

69

69
0.012

0.006

$\frac{\text { Type-Curve Matching }}{\mathrm{T}\left(\mathrm{m}^{2} / \mathrm{d}\right)}$

67

0.013

65 
Figure 5.16 shows a diagnostic $\log -\log$ plot of drawdown and drawdown derivative. The derivative calculation method and associated diagnostic techniques are described in Spane and Wurstner (1993). The derivative plot indicates radial flow conditions, as shown by the flattening of the derivative curve, after about 100 minutes of pumping.

The Cooper and Jacob (1946) semi-log straight-line analysis method was applied to the data, as shown in Figure 5.17. Application of this method assumed that flow to the well screen is strictly horizontal (i.e., no partial penetration effects) and that the results are representative of the screened interval. Given these assumptions, transmissivity was estimated to be approximately $0.6 \mathrm{~m}^{2} / \mathrm{d}\left(6 \mathrm{ft}^{2} / \mathrm{d}\right)$. Transmissivity divided by the thickness of the test interval, which is $1.5 \mathrm{~m}(5 \mathrm{ft}$ ), yielded an estimate for equivalent hydraulic conductivity of approximately $0.3 \mathrm{~m} / \mathrm{d}(1 \mathrm{ft} / \mathrm{d})$.

The drawdown data were not analyzed using type-curve matching techniques because of uncertainties associated with analyzing nonformational pressure responses (i.e., wellbore responses). These nonformational responses common to constant-rate pumping tests include well inefficiencies and wellbore storage effects.(Spane 1993).

\section{Well 299-W11-32 (Bottom Screen) Test Results}

A 12-hour constant-rate pumping test was conducted in the bottom screened interval of well 299-W11-32 on January 12, 1994. The test interval was at a depth of 89 to $91 \mathrm{~m}$ (293 to $298 \mathrm{ft}$ ), 14 to $16 \mathrm{~m}$ ( 46 to $51 \mathrm{ft}$ ) below the water table. An inflatable packer was placed in the blank casing between the middle and bottom screens, to isolate the bottom screen from the two upper screens. The submersible pump intake was located below the inflated packer at a depth of approximately $91 \mathrm{~m}(297 \mathrm{ft})$. The flow rate at the stressed interval was $19 \mathrm{~L} / \mathrm{m}(5 \mathrm{gpm})$, which was measured by the time required to fill a known volume (i.e., 19-L [5-gal] bucket).

Drawdown pressure responses were monitored in all three screened intervals of well 299-W11-32 and in wells 299-W11-29 and 299-W11-30. During recovery, the check valve leaked, causing water in the discharge line to flow back into the formation. The maximum pressure response observed in the test interval was about $2 \mathrm{~m}(8 \mathrm{ft})$. Pressures in the top two screens and in the two observation wells did not respond to pumping.

A diagnostic log-log plot of drawdown and drawdown derivative is shown in Figure 5.18. The derivative plot shows that radial flow conditions begin to dominate after about 100 minutes of pumping. However, significant scatter in the derivative data after about 200 minutes (not shown) reffects pressure fluctuations during the latter part of the test. The cause of these pressure fluctuations is not known.

The Cooper and Jacob (1946) straight-line solution was applied to a semi-log time-drawdown plot of the data, as shown in Figure 5.19. Application of this method assumed that flow to the well screen is strictly horizontal (i.e., no partially penetration effects) and that the results are representative of the screened interval. Given these assumptions, transmissivity was estimated to be approximately $17 \mathrm{~m}^{2} / \mathrm{d}$ $\left(180 \mathrm{ft}^{2} / \mathrm{d}\right)$. Transmissivity divided by the thickness of the test interval, which is $1.5 \mathrm{~m}(5 \mathrm{ft})$, yielded an estimate for equivalent hydraulic conductivity of approximately $11 \mathrm{~m} / \mathrm{d}(36 \mathrm{ft} / \mathrm{d})$. 


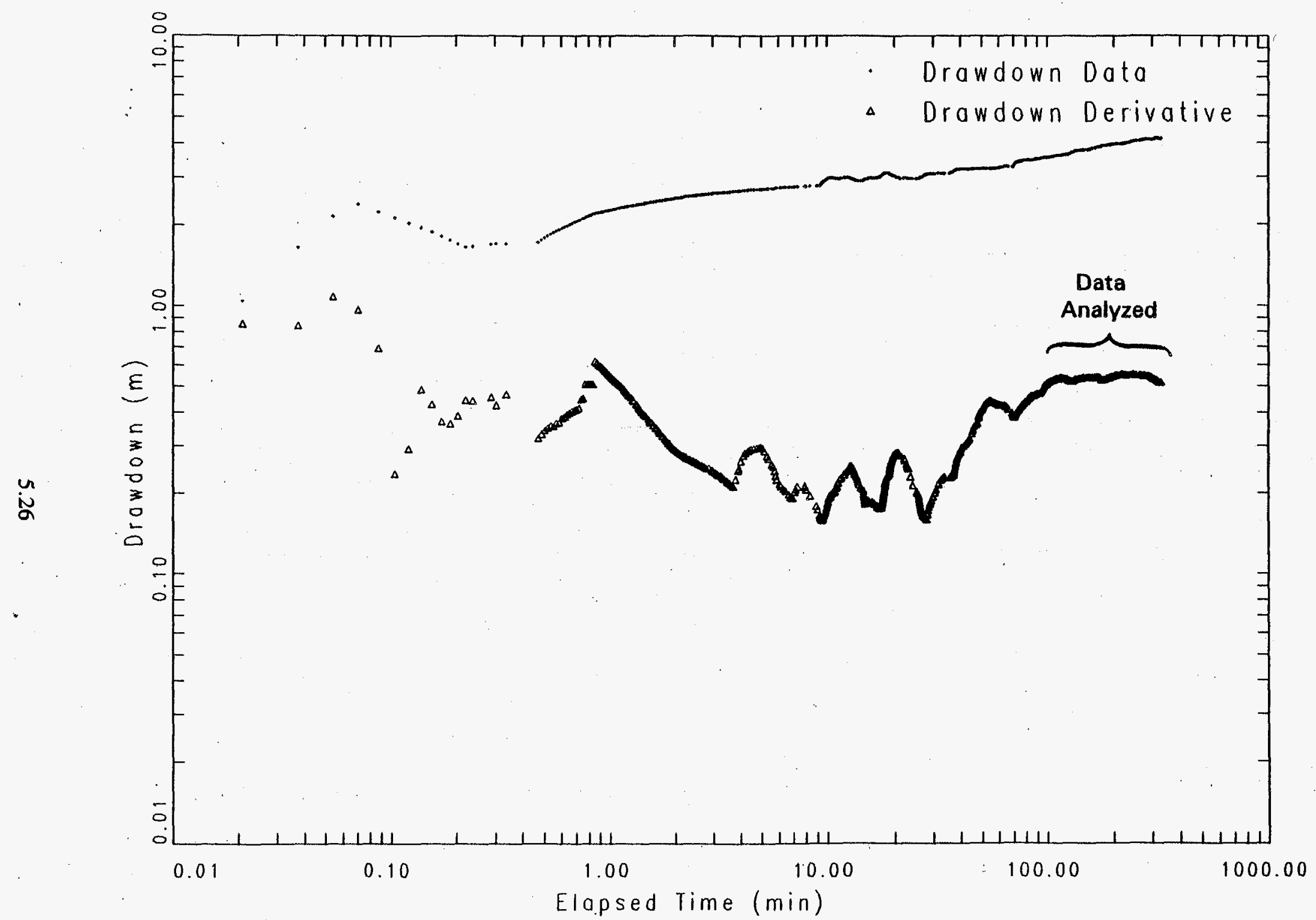

Figure 5.16. Diagnostic Plot of Drawdown and Drawdown Derivation for the Middle Screened Interval of Well 299-W11-32 


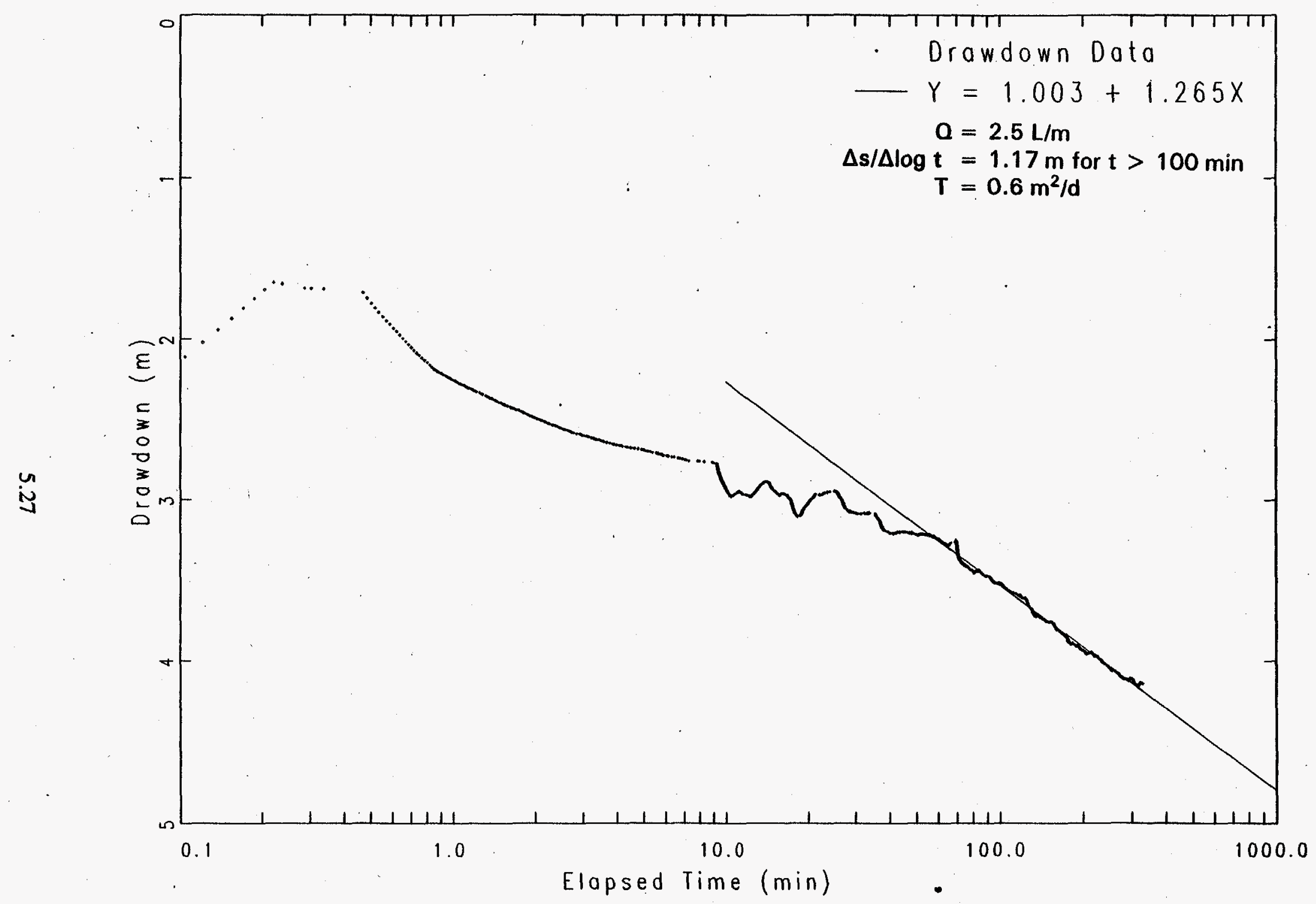

Figure 5:17. Straight-Line Drawdown Data Analysis for the Middle Screened Interval of Well 299-W11-32 


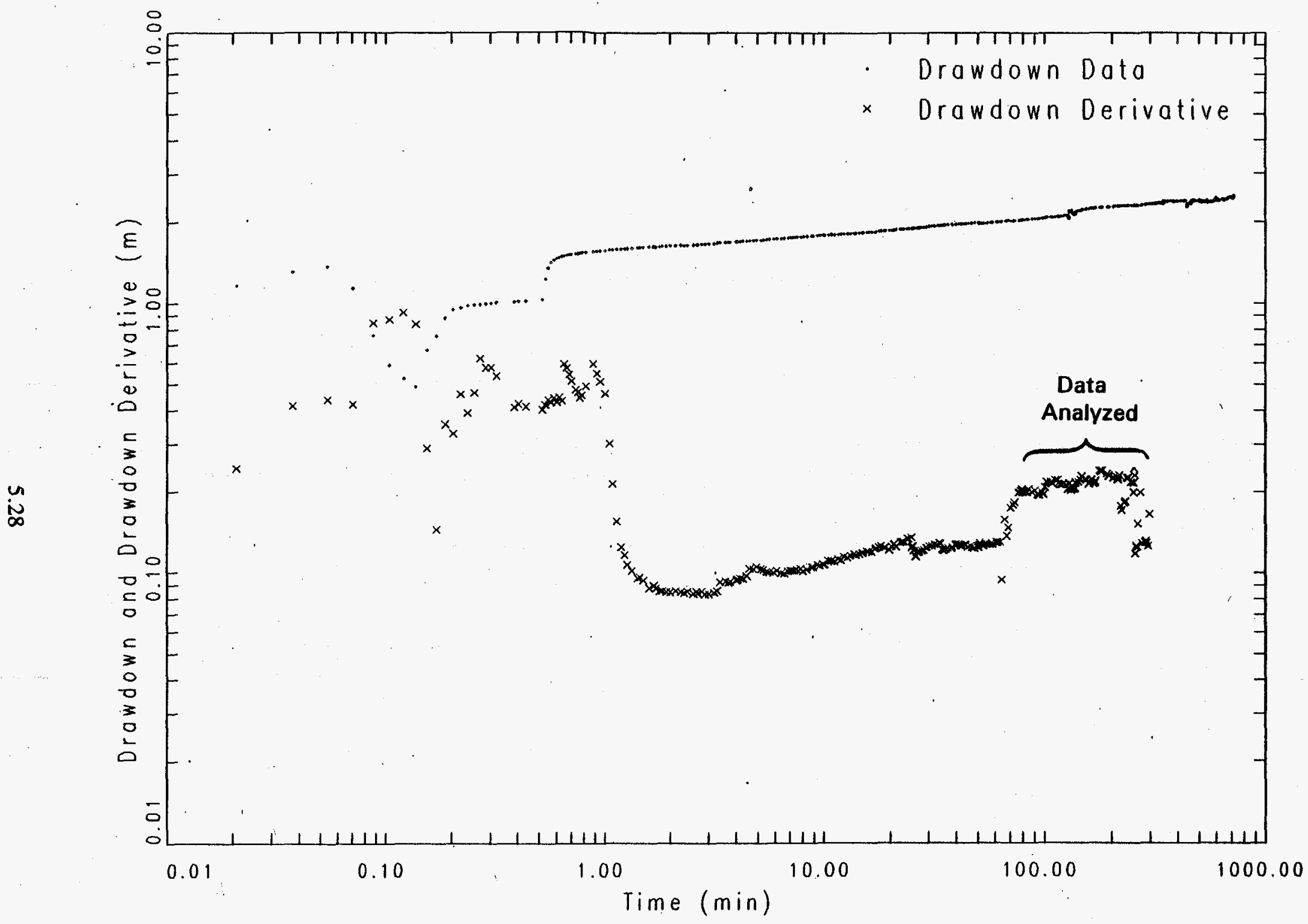

Figure 5.18. Diagnostic Plot of Drawdown and Drawdown Derivation for the Bottom Screened Interval of Well 299-W11-32 


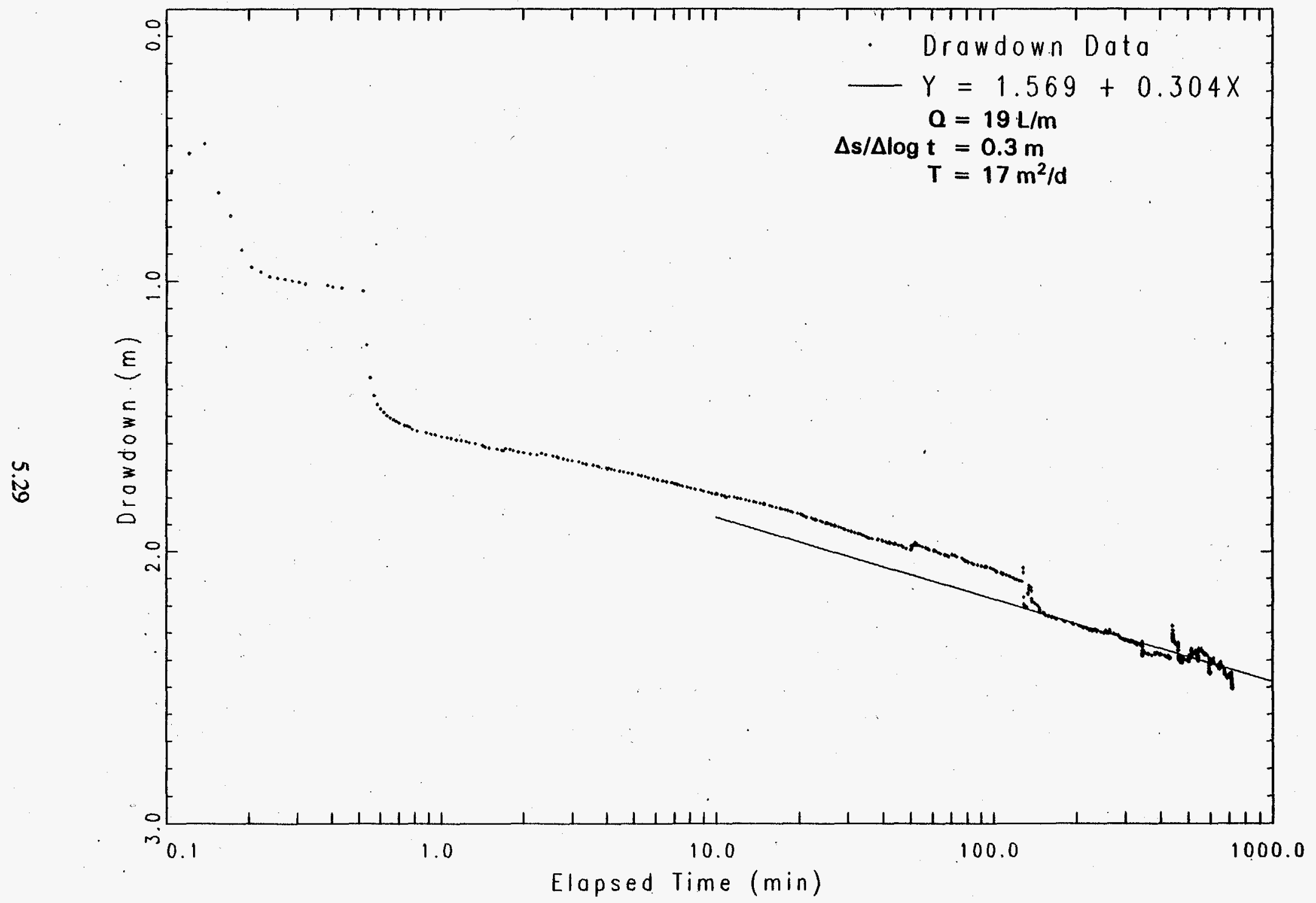

Figure 5.19. Straight-Line Drawdown Data Analysis for the Bottom Screened Interval of Well 299-W11-32 
The drawdown data were not analyzed using type-curve matching techniques because of uncertainties associated with nonformational pressure responses (i.e., wellbore responses). These nonformational responses common to constant-rate pumping tests include well inefficiencies and wellbore storage effects (Spane 1993).

\subsubsection{Slug Displacement Tests}

Slug displacement tests using pressurized nitrogen were conducted in the middle and bottom screened intervals of well 299-W11-32. These tests were conducted on test intervals at depths of 83 to

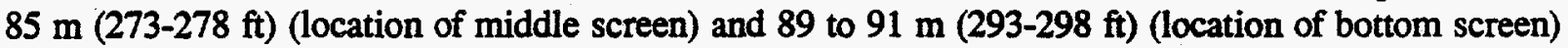
to determine horizontal hydraulic conductivity of the formation adjacent to the test interval.

Figure 5.20 shows a diagram of the test configurations.

Inflatable packers were used to isolate each test interval and compressed nitrogen was used to depress the water column within a 5-cm (2-in.) inside diameter riser pipe. Access between the water column,and the test interval was via a tube running through the packer and perforated adjacent to the test interval.

Five tests were conducted in the middle screened interval on November 18, 1993, but only three produced analyzable results. Four analyzable displacement tests were conducted in the bottom screened interval on November 19,1993 . The stress level $\mathrm{H}_{\mathrm{o}}$ (i.e., height of water column depressed) for each test is presented in Table 5.4. The tests were conducted at various stress levels using pressurized nitrogen to depress the water column. After reaching equilibrium, the water column was instantaneously depressurized and pressure responses were measured until nearly full recovery was established. Analytical methods, including a straight-line technique and a type-curve matching technique were used to analyze the pressure recovery data, as described below.

\section{Bouwer and Rice Analysis Method}

The Bouwer and Rice (1976) method employs a straight-line fit to a semi-log plot of pressure recovery data versus time. This method is based on a steady-state solution and empirical dimensionless parameters for the well geometry derived from electric analog studies. It accounts for partial penetration of an unconfined aquifer, but does not consider aquifer elastic storage properties.

For the analysis, the aquifer was assumed to be fully penetrating (i.e., the aquifer thickness equals the test interval of $1.5 \mathrm{~m}(5 \mathrm{ft})$ for tests conducted in both screened intervals. This assumes that vertical flow during the slug tests was negligible compared to horizontal flow and that hydraulic conductivity is representative of the test interval (well screen). Full penetration can reasonably be assumed because pressures in the screen(s) above or below the test intervals did not respond during testing. Furthermore, the pressures at these monitoring locations did not respond to pumping of the test intervals during development and constant-rate discharge testing. It is also assumed that heterogeneity over the test interval has little affect on the test results (i.e., assume homogeneous conditions). The effective well radius, which accounts for the artificial filter pack around the test interval, was calculated to be $0.12 \mathrm{~m}(0.39 \mathrm{ft})$, using an equation from Bouwer (1989). 


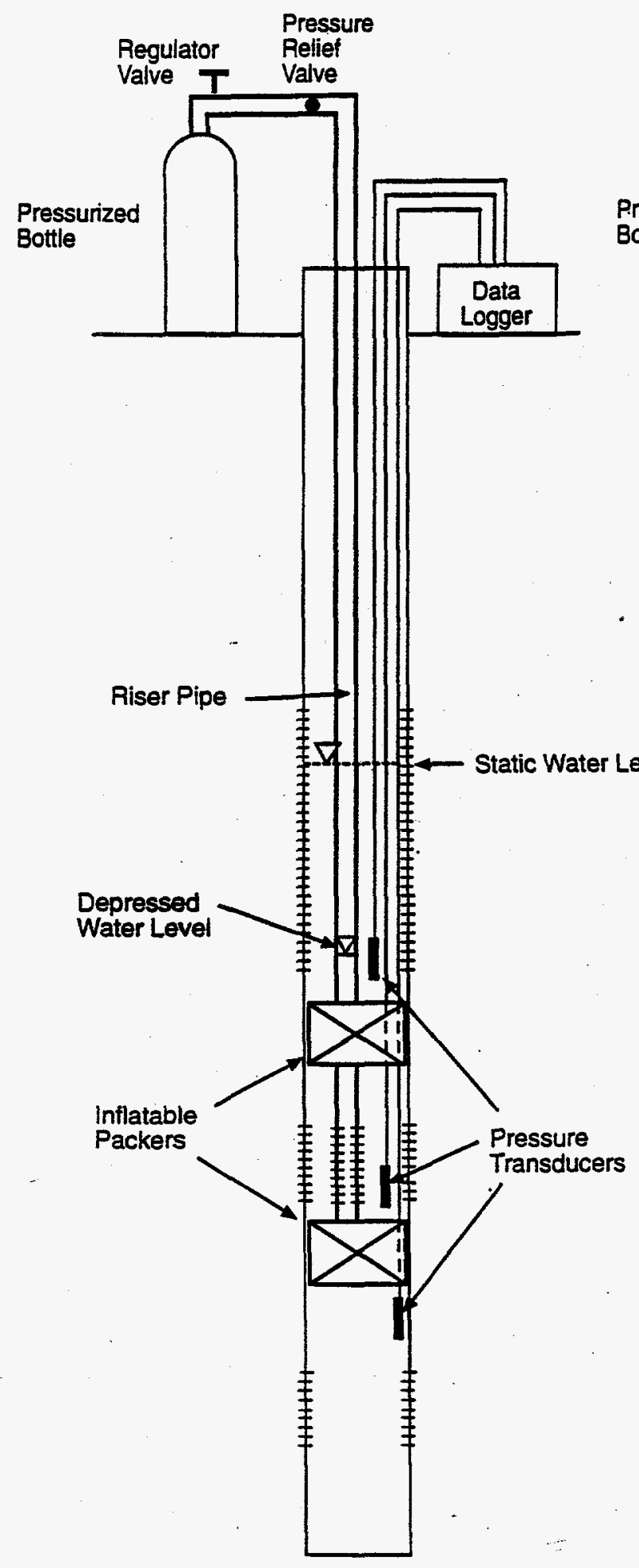

(a)

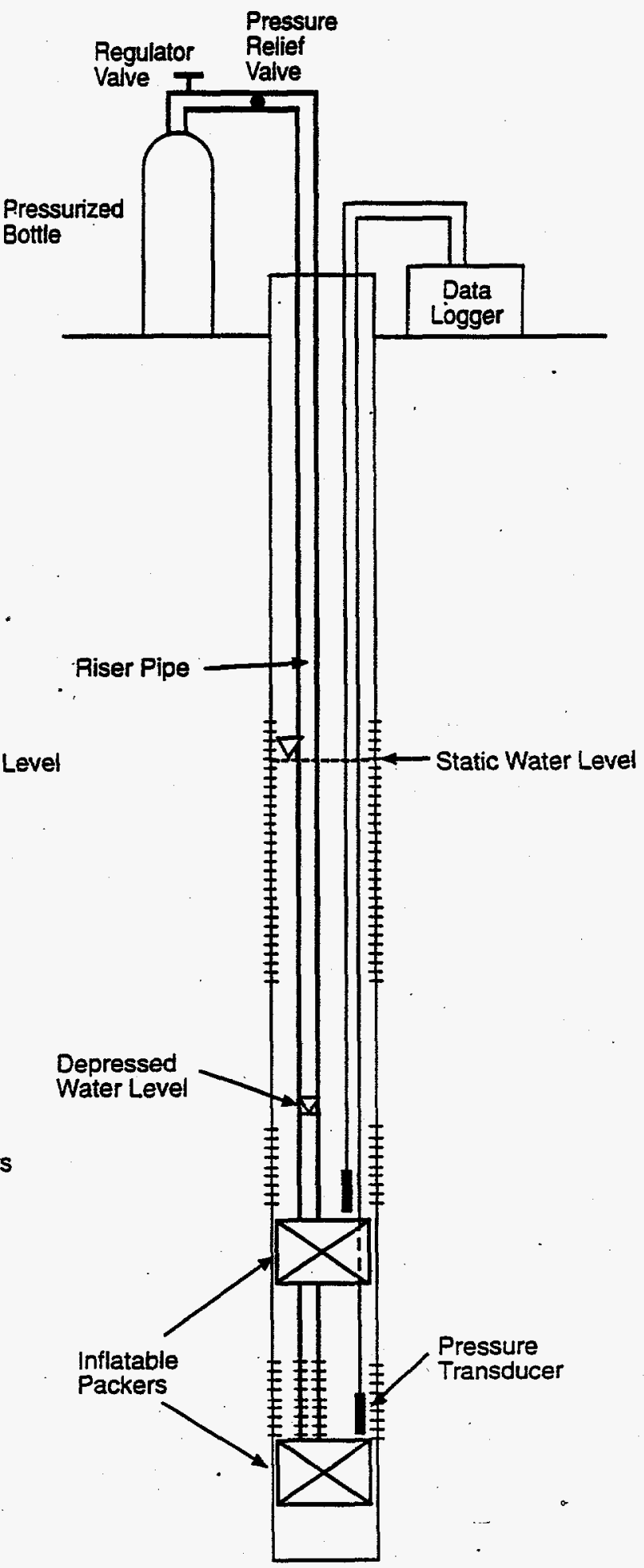

(b)

Figure 5.20. Slug Test Configuration for a) Middle Screened Interval and b) Bottom Screened Interval of Well 299-W11-32 
Table 5.4. Results of Slug Displacement Tests Conducted in Well 299-W11-32

\begin{tabular}{|c|c|c|c|c|}
\hline Test Interval & Test Number & $\mathrm{H}_{\mathrm{o}}(\mathrm{m})$ & $\begin{array}{c}\text { Bouwer and } \\
\text { Rice } \\
\text { Method } \\
K_{h}(m / d)\end{array}$ & $\begin{array}{c}\text { Type-Curve } \\
\text { Method } \\
K_{h}(m / d)\end{array}$ \\
\hline Middle & 3 & 5 & 2.4 & 3 \\
\hline Middle & 4 & 5 & 2.3 & 3 \\
\hline Middle & 5 & 3 & 2.8 & 4 \\
\hline Bottom & 1 & 6 & 28 & 43 \\
\hline Bottom & 2 & 9 & 25 . & 37 \\
\hline Bottom & 3 & 11 & 22 & 30 \\
\hline Bottom & 4 & 11 & 22 & 30 \\
\hline
\end{tabular}

A semi-log plot of pressure recovery $\left(Y_{t}\right)$ versus time for one of the three slug tests conducted in the middle screened interval is shown in Figure 5.21. A semi-log plot for one of the tests conducted in the bottom screened interval is shown in Figure 5.22. A summary of the slug test analysis results is presented in Table 5.4. Test results from the middle screened interval yiedded estimates for horizontal hydraulic conductivity between 2.3 and $2.8 \mathrm{~m} / \mathrm{d}(7.6$ and $9.3 \mathrm{ft} / \mathrm{d})$. Test results from the bottom screened interval yielded estimates ranging between 22 and $28 \mathrm{~m} / \mathrm{d}(71$ and $91 \mathrm{ft} / \mathrm{d})$.

\section{Type-Curve Analysis Method}

Slug test type curves applicable to each of the test intervals were developed by converting equivalent pumping test type curves according to methods described in Peres et al. (1989) and Spane (1994). The pumping test type curves were generated using a modification of the DELAY2 computer program described in Neuman (1975). Pressure derivatives for both the test data and the type curves were calculated in Spane and Wurstner (1993). The dimensionless type curve and derivative of the type curve were simultaneously matched with the pressure data and derivative of the pressure data to obtain estimates for transmissivity.

Analysis type curves assumed a fully penetrated, unconfined aquifer and accounted for elastic storage properties and wellbore storage. Again, as described above for the straight-line technique, full penetration assumes that vertical flow during the slug tests was negligible compared to horizontal flow and that hydraulic conductivity is representative of the test interval (well screen). The storativity was assumed to be 0.001 , which is within the range expected for unconfined aquifers. Using the equation in Bouwer (1989), the effective well radius was calculated to be $0.12 \mathrm{~m}(0.39 \mathrm{ft})$ :

For the type-curve matching technique, semi-log plots for one of the slug tests conducted in the middle screened interval and one for the bottom screened interval are shown in Figures 5.23 and 5.24, respectively. A summary of the slug test analysis results is presented in Table 5.4. Test results from 


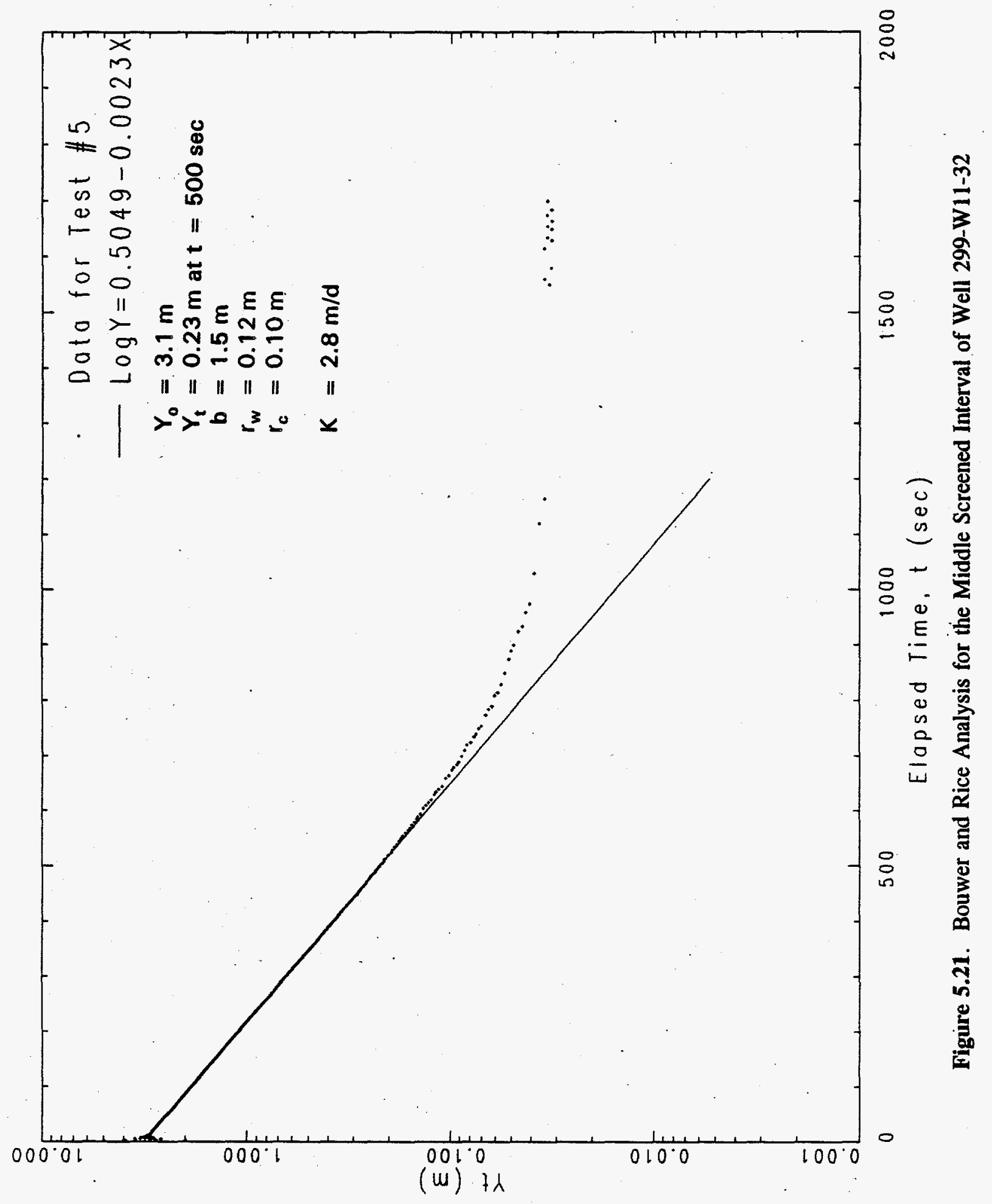




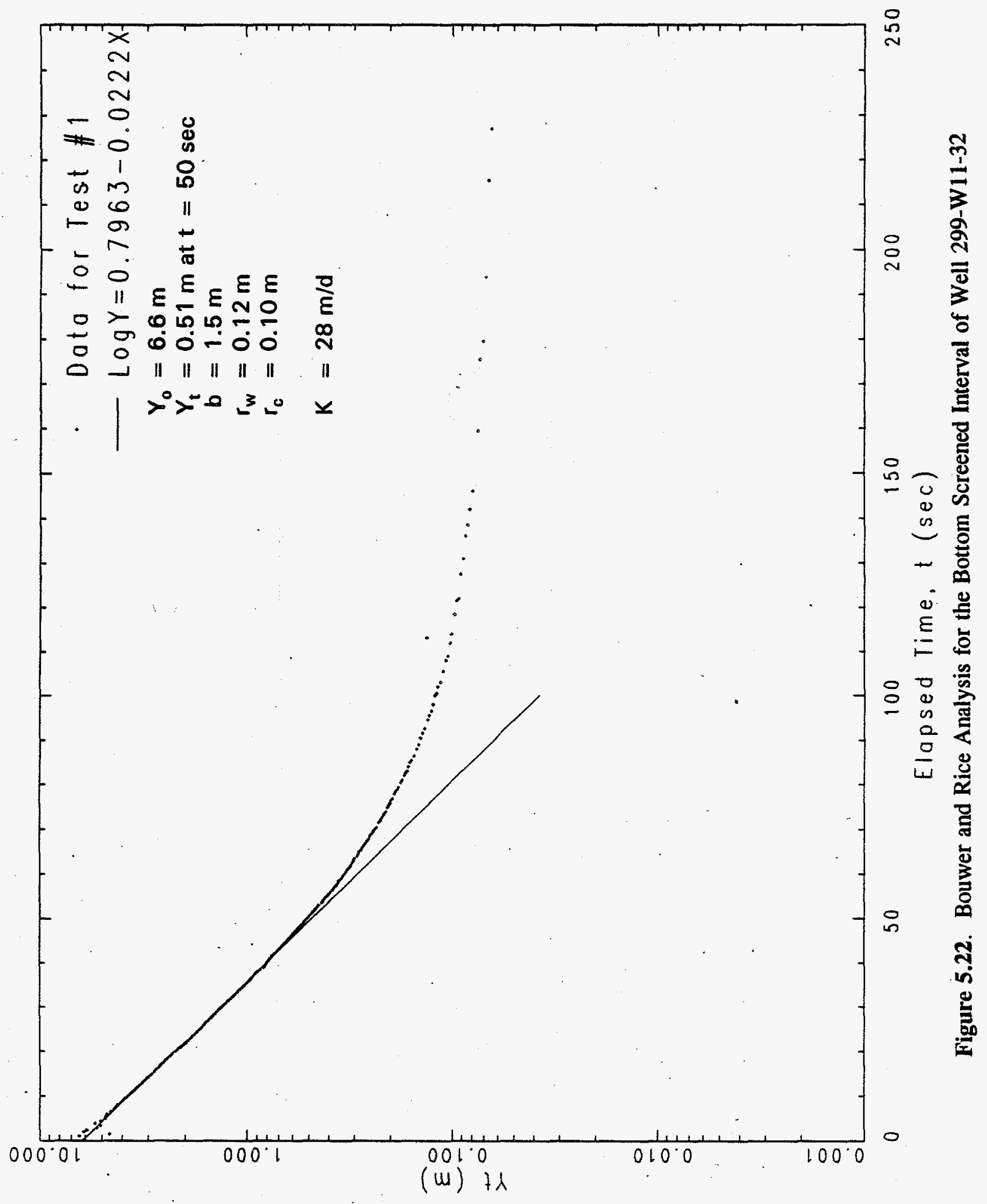




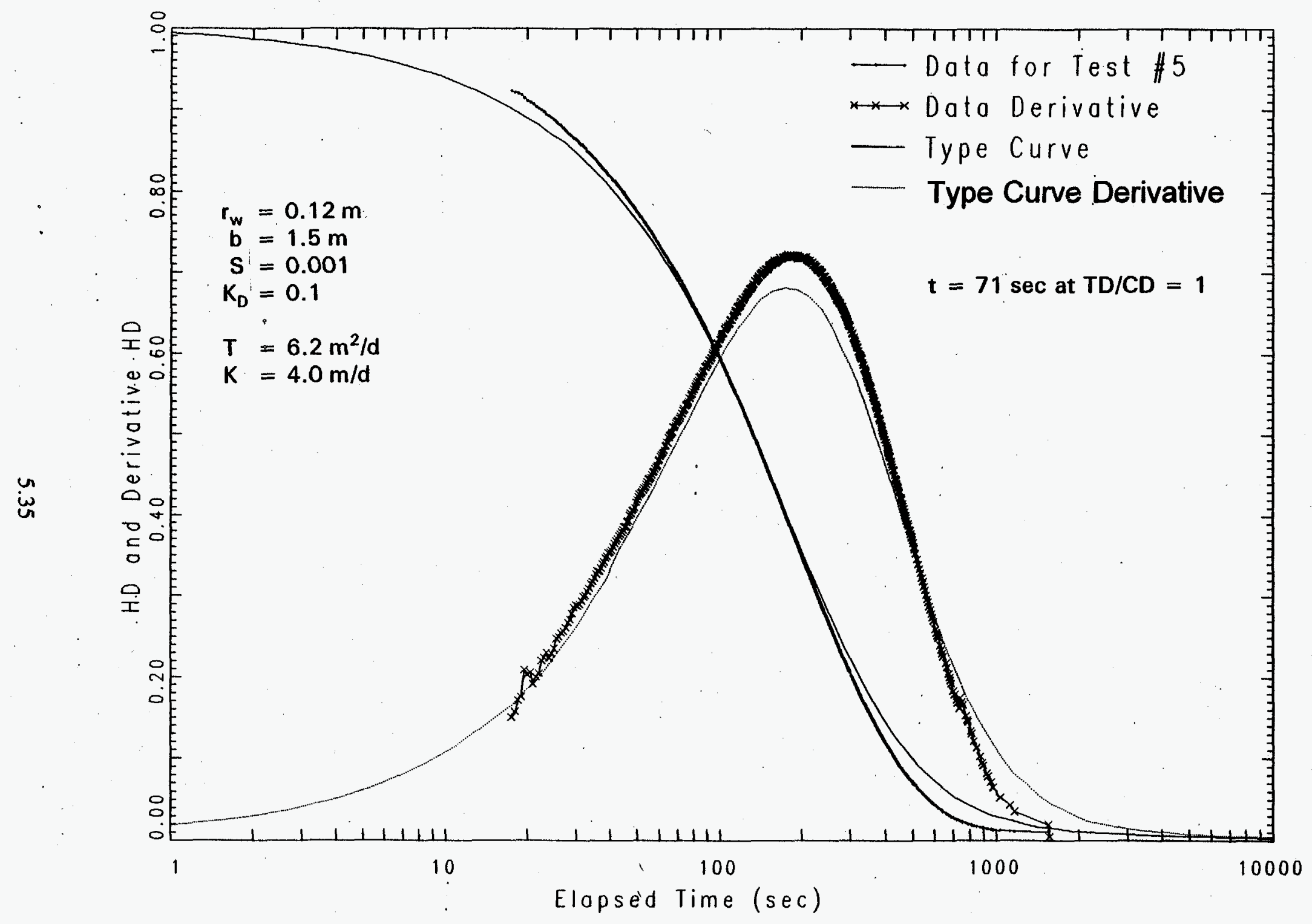

Figure 5.23. Slug Test Type-Curve Analysis for the Middle Screened Interval of Well 299-W11-32 


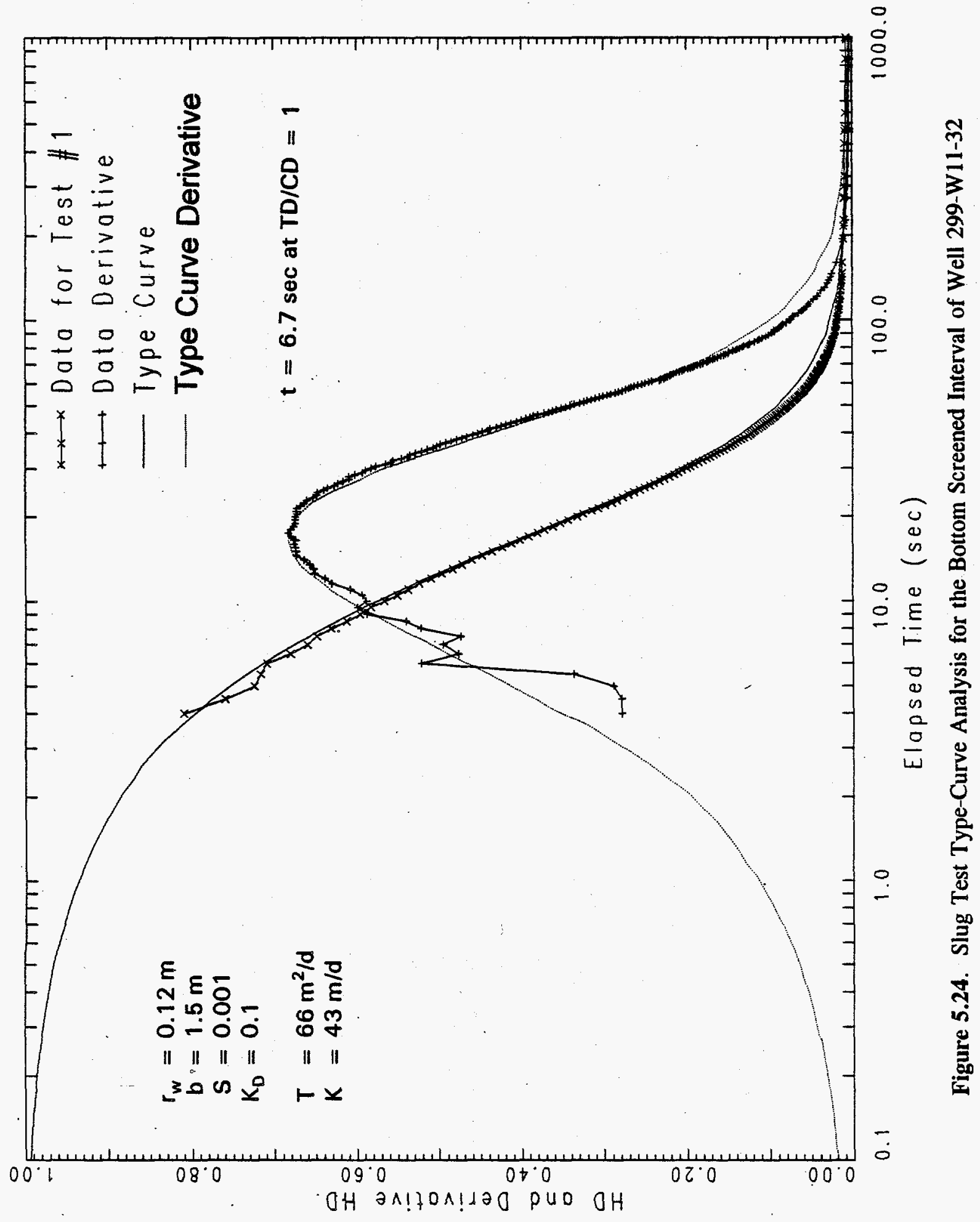


the middle screened interval yielded estimates for hydraulic conductivity ranging between 3 and $4 \mathrm{~m} / \mathrm{d}$ $(10 \mathrm{ft} / \mathrm{d}$ and $13 \mathrm{ft} / \mathrm{d})$. Test results from the bottom screened interval yielded estimates ranging between 30 and $43 \mathrm{~m} / \mathrm{d}(100 \mathrm{ft} / \mathrm{d}$ and $140 \mathrm{ft} / \mathrm{d})$.

\subsection{Ground-Water Tracer Tests}

A series of ground-water tracer tests was conducted in wells 299-W-11-29 and 299-W11-30. Pointdilution tests were conducted in wells 299-W11-29 and 299-W11-30. A drift-and-pumpback test was conducted in well 299-W11-30, and a natural gradient tracer test was conducted between the two wells.

Tracer testing began at the bioremediation test site on June 8, 1992. At that time, a drift-andpumpback test using a lithium bromide tracer was attempted at well 299-W11-30 in the manner described by Hall et al. (1991). A drift-and-pumpback test is conducted by introducing a tracer into the well and allowing it to drift away from the well under the natural hydraulic gradient. The well is then pumped and the concentration of the recovered tracer is monitored with time. The net seepage velocity and the effective porosity of the aquifer are then calculated from the time required to recover the center of mass of the tracer.

For the tracer solution, a volume of $4.6 \mathrm{~L}$ of water was used to dissolve $80 \mathrm{~g}$ of lithium bromide. The tracer was allowed to drift until June 18,1992 . On that date, the well was pumped at a discharge rate of approximately $38 \mathrm{~L} / \mathrm{m}(10 \mathrm{gpm})$ to recover the tracer, and the bromide concentration of the discharge stream was monitored in the field using ion-selective electrodes. Results of this test were inconclusive for two reasons. First, recovery pumping showed that the tracer had not moved far enough from the well bore to constitite a valid test. Second, the local hydraulic gradient was not accurately known.

Because of these uncertainties, effective porosity could not be determined, but an upper bounding limit of $0.03 \mathrm{~m} / \mathrm{d}(0.1 \mathrm{ft} / \mathrm{d})$ for the ground-water flow velocity was obtained. This velocity was confirmed by a two-well tracer test conducted under natural gradient, where a second tracer slug was introduced into well 299-W11-29, and well 299-W11-30, which is downgradient from 299-W11-29, was monitored for bromide.

To conduct the two-well test, a tracer slug identical to the one used previously for the drift-andpumpback test was injected on July 28,1992 . The tracer was allowed to drift under natural hydraulic gradient, and the tracer concentration was monitored in the downgradient well, 299-W11-30, every

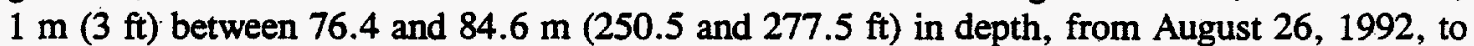
December 3, 1992. Measurements- were taken with a downhole ion-selective electrode every 1 to 2 weeks. No bromide was detected during this period, and use of the electrode was discontinued. Ground-water samples were subsequently collected from the top of the water column over a period of about 2 months, approximately every 2 weeks, between December 28, 1992, and March 2, 1993. These samples were analyzed in the laboratory using bromide ion-selective electrodes. The data indicate that the outer fringe of the tracer slug passed through the downgradient well.

Concentrations were quite low ( $\leq 1 \mathrm{mg} / \mathrm{L}$ ), and it is apparent that the center of mass of the tracer slug did not pass through the monitored well. Inspection of local and regional water-level data indicates that although the water table is lower in elevation at well 299-W11-30 than at well 
299-W11-29, the ground-water flow may not be parallel to axis of the wells (see section on water-level data). Thus, while accurate interpretation of the bromide data was not possible, first detection of bromide at the monitored well suggests a ground-water flow rate of approximately $0.03 \mathrm{~m} / \mathrm{d}(0.1 \mathrm{ft} / \mathrm{d})$, a rate which is consistent with the upper bounding limit estimated from the drift-and-pumpback test.

Point-dilution tests were conducted in the manner described in Hall (1993) immediately following initial tracer injection for both the drift-and-pumpback test and the dual-well test. In both cases, the submersible ion-selective electrode was used to measure bromide concentration as a function of both depth (1-m [3-ft] intervals) and time. Difficulty with the sensing electrode was encountered during the June 8, 1992, test, and measurements were abandoned after 2 hours. The instrument problem was corrected, and the July 28 test was completed successfully. The results of that test are discussed below within the context of more recent point-dilution tests conducted at the two wells.

On January 5, 1994, point-dilution tests were conducted at wells 299-W11-29 and 299-W11-30. Before the test, the standing water column of each well was estimated to be approximately $30 \mathrm{ft}$. Because both wells are constructed with a $10.2-\mathrm{cm}$ (4-in.) inner diameter, the volume of water in each borehole was approximately $74 \mathrm{~L}$. A tracer charge of $25 \mathrm{~g}$ of potassium bromide per well was chosen to yield an initial concentration of approximately $230 \mathrm{mg} / \mathrm{L}$ as bromide when the tracer is evenly distributed in the water column of each well.

Tracer injection was accomplished using a 2.5-cm (1-in.) inside diameter (ID) flexible plastic hose and a two-stage 8.9-cm (3.5-in.) outside diameter (OD) static-in-line mixer. Both ends of the hose were left open, and the mixer was suspended from the end of the hose. The hose was lowered into each well so that the mixer just reached total depth. Then, the tracer was mixed in a volume of distilled water equal to the volume of water displaced by the hose between total depth and the water table (in both cases approximately $4.6 \mathrm{~L}$. The tracer solution was then poured down the hose, thereby displacing ground water within the hose. When the hose was retrieved, the tracer slug was left in the well and mixed within the well bore. The time of injection was considered to be the midpoint of the period of time needed to fetch the lower end of the hose from total depth to water table.

After tracer injection, bromide concentration in each well bore was measured as a function of time and depth using bromide-sensing electrodes. Each instrument was calibrated immediately before the test to determine response slope (i.e., change in instrument response per unit change in the $\log _{10}$ of the bromide concentration) and the instrument response to a $1.0 \mathrm{mg} / \mathrm{L}$ bromide solution. With these values, the bromide concentration can be directly calculated from instrument response in millivolts (E).

The tracer tests were conducted simultaneously. The electric cables used to deploy the instruments were marked in 1-m (3-ft) increments to facilitate depth-discrete measurements of tracer concentration. Figures 5.25 and Figure 5.26 show millivolt instrument response as a function of time for each measurement depth in wells 299-W11-29 and 299-W11-30, respectively.

Hall (1993) noted that in a valid point-dilution experiment, the instrument response in $\mathrm{E}$ as a function of time (t) will tend towards a straight line, but that non-ideal mixing early in the experiment often causes an initial curvilinear response. Inspection of Figures 5.25 and 5.26 shows that the individual plots support straight-line interpretation for most of the depth intervals. Hall also noted that, where ground-water flow is dominated by horizontal advection, the slope of each plot, $\mathbf{d E} / \mathrm{dt}$, is directly proportional to the velocity of ground water through the well bore, and normal to the bore axis, at the measurement depth. Further, Palmer (1993) has shown that in a minimally developed well the velocity through the well bore is directly proportional to hydraulic conductivity. 

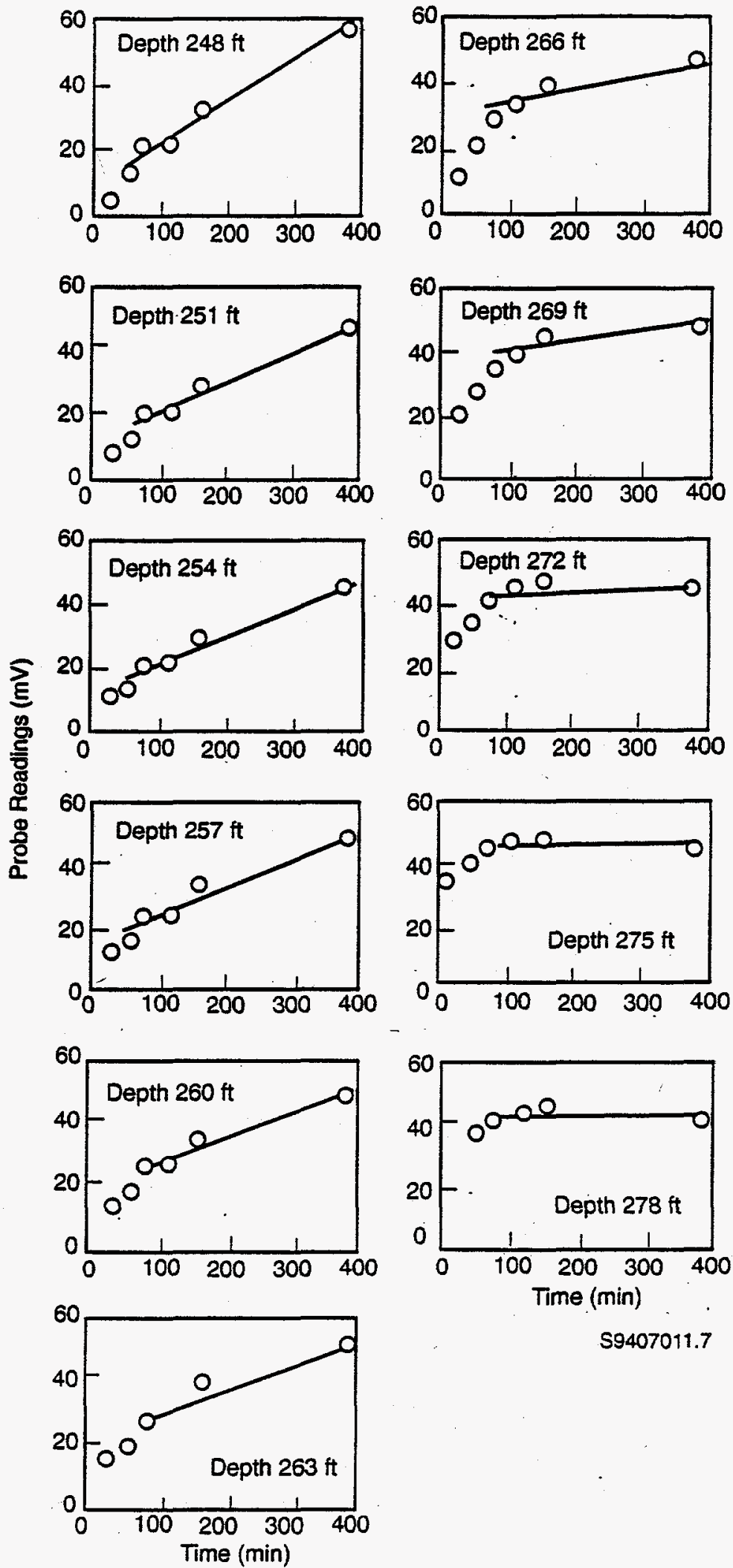

$\$ 9407011.7$

Figure 5.25. Point-Dilution Test Results of Well 299-W11-29 for January 1994 

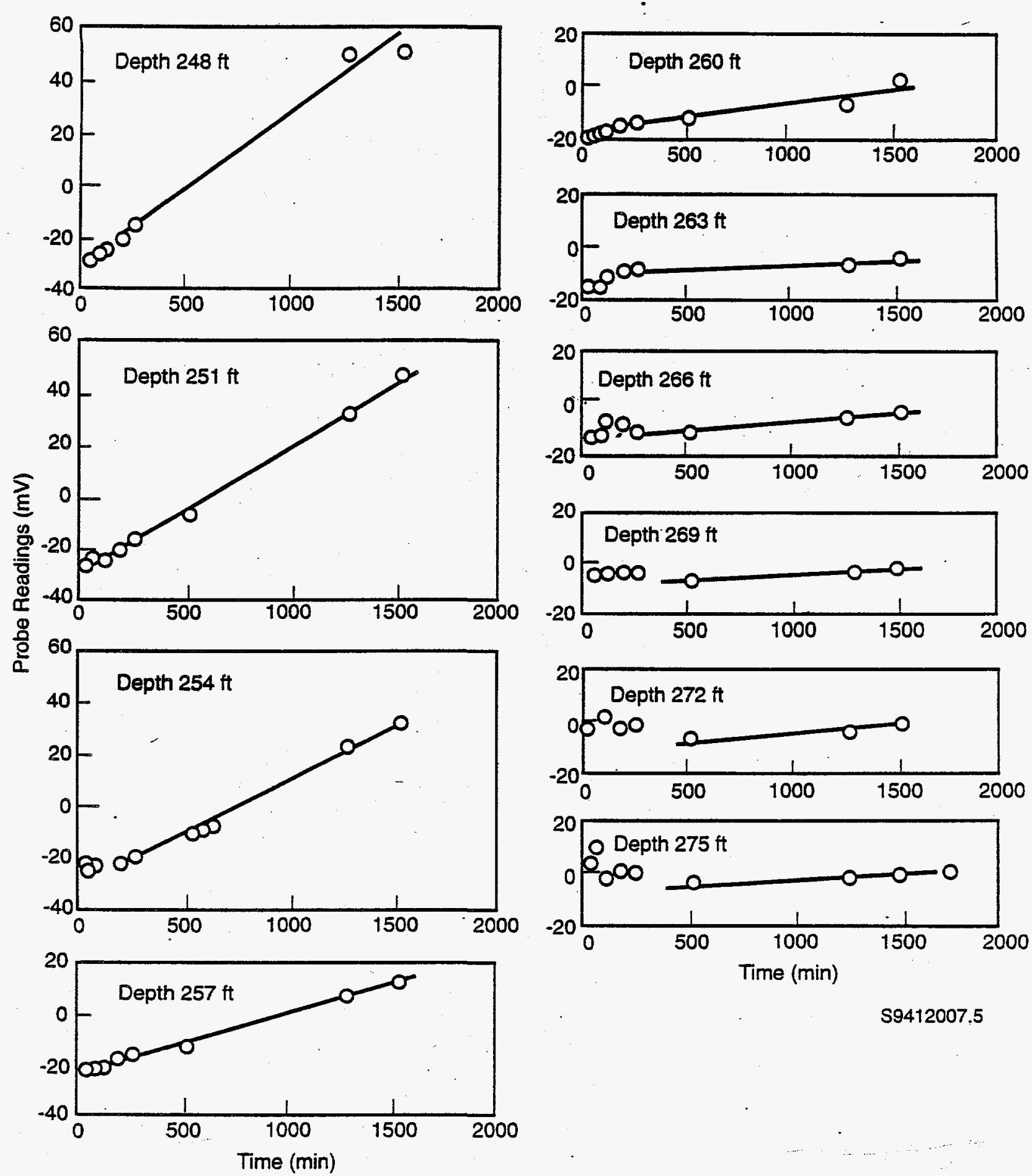

$\$ 9412007.5$

Figure 5.26. Point-Dilution Test Results of Well 299-W11-30 for January 1994 
Within the context of point-dilution experiments, it must be emphasized that "minimal development" may not be interpreted as. "poor development." Well development must be sufficient to ensure that the hydraulic conductivity of the well screen and packing material is much greater than that of the surrounding aquifer. Further, development must be sufficient to negate any skin effect on the circumference of the borehole caused during initial drilling (e.g., drilling mud cake). Palmer's "minimally developed well" is that well which has not been pumped enough to remove a significant amount of fines from the surrounding aquifer. That is, the hydraulic conductivity of the aquifer immediately adjacent to the well installation must not have been affected by the pumping history of the well.

Where Palmer's conditions are satisfied, a plot of $\mathbf{d E} / \mathbf{d t}$ versus depth represents relative hydraulic conductivity as a function of depth. Neither well 299-W11-29 nor well 299-W11-30 has been extensively pumped. It is assumed that development has been adequate. Therefore, Figure 5.27 is presented as a representation of the relative hydraulic conductivities in the immediate vicinity of the two wells. In the figure, all values for $\mathbf{~ d E / d t ~ f r o m ~ t h e ~ J a n u a r y ~} 1994$ tests have been normalized to the largest dE/dt measured (i.e., at a depth of $76 \mathrm{~m}$ [248 ft], well 299-W11-29).

The results of the January 1994 tests show that the mean hydraulic conductivity at well 299-W11-30 is approximately $37 \%$ of that at well $299-$ W11-29. Note that observation well drawdown data obtained from pumping tests at wells 299-W11-30 and 299-W11-32 yielded approximately the same transmissivity values. This occurs because use of an observation well yields a transmissivity value that reflects the mean characteristics of the sediments lying between the two wells. In both instances, the same body of sediments was interrogated. The point-dilution test, on the other hand, reflects characteristics of the sediments only in the immediate vicinity of a well.

Figure 5.27 shows that most ground-water mass transport occurs in the upper half of the saturated interval. (Note that the differences in conductivity may not be interpreted as differences in flow velocity.) However, the difference in mean conductivity between the two wells may suggest significant local variability in the hydraulic characteristics of the sediments because of heterogeneities within layers. The necessary consequence is that, even if flow is dominated by horizontal advection, horizontal flow vectors within any given horizon cannot be assumed to be linear.

Figure 5.27 also shows the results of the 1992 point-dilution test at well 299-W11-29. Note that for these data, the mean value for $\mathbf{~ E E / d t ~ h a s ~ b e e n ~ n o r m a l i z e d ~ t o ~ t h e ~ m e a n ~ v a l u e ~ f r o m ~ t h e ~} 1994$ tests from that well. This is reasonable because the net transmissivity of the well is not expected to have changed. The results of the 1992 test indicate much less contrast in conductivity with depth than do the results of the 1994 test. It is believed that this was caused by vertical mixing induced in the well bore by periodically moving the bromide sensing electrodes up and down the well. Some curvature observed in the plots of $\mathbf{E}$ versus $\mathbf{t}$ obtained in 1992 support this interpretation. However, it is also possible that the difference between the 1992 and the 1994 tests reflects seasonal variations (e.g., summer versus winter).

The submersible ion-selective electrode instruments used to detect bromide in the 1994 tests were an improved version compared to the relatively. crude prototype described in Hall (1993) and used in the 1992 tests. The improved version of the downhole sonde is a streamlined combination-type instrument (reference and sensing electrodes contained in a single body), $1.5 \mathrm{~cm}(0.6 \mathrm{in}$.) in diameter, and approximately $20 \mathrm{~cm}(8 \mathrm{in}$.) long. In contrast, the electrode assembly used in the earlier test presented a much larger, unstreamlined cross-section, which, in a 10.2-cm (4-in.) well would, in retrospect, be likely to induce mixing (tests described in Hall [1993] were conducted in 25.4-em (10-in.) wells). 


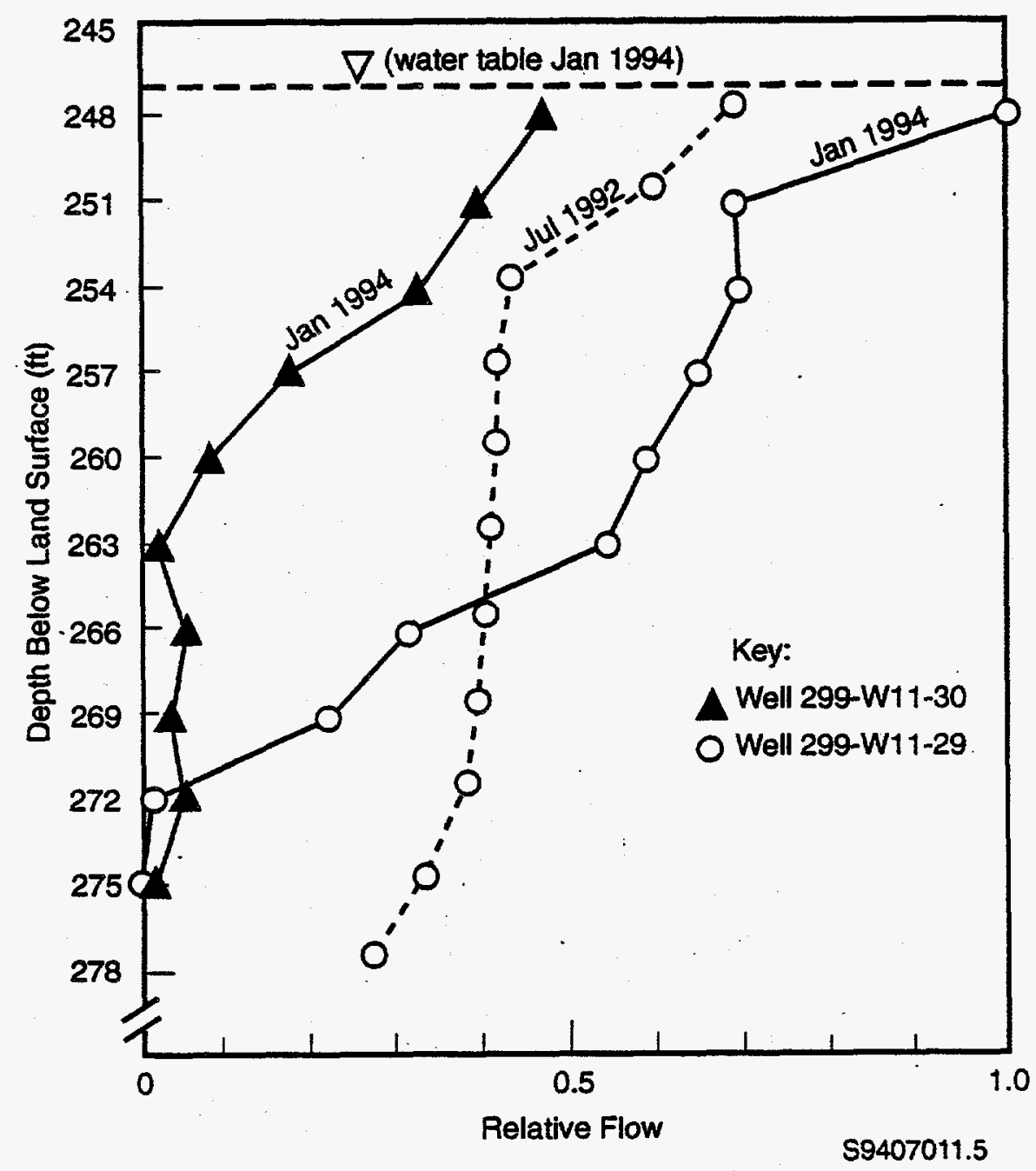

Figure 5.27. Relative Horizontal Ground-Water Flow Velocity Through the Well Bore as a Function of Depth for Wells 299-W11-29 and 299-W11-30

\subsubsection{Discussion}

Point-dilution tests have shown that most aqueous mass transport within the tested depth interval at the bioremediation test site occurs in approximately the upper half of the sediments. If conditions imposed by Palmer (1993) are considered to have been met for the test wells, then the test results quantitatively reflect the vertical distribution of hydraulic conductivity within each well bore, and with respect to each other.

The considerable difference between the July 1992 and the January 1994 test results for well 299-W11-29 may be either a result of seasonal variations in hydraulic gradient or an artifact of vertical mixing induced in the well bore during the 1992 test. It is quite possible that the difference was caused 
by a combination of both factors. Difficulty in accurately measuring the very shallow local hydraulic gradient has made it very difficult to detect seasonal changes.

Difficulty in gradient measurement has also rendered single-well drift-and-pumpback tests impractical. A two-well test has indicated that the mean ground-water migration rate, over the period July to March, is roughly $0.03 \mathrm{~m} / \mathrm{d}(0.1 \mathrm{ft} / \mathrm{d})$. However, without firm knowledge of gradient, the effective porosity of the sediments cannot be directly estimated.

\subsection{Water-Level Monitoring}

Water-level measurements have been collected approximately on a monthly schedule from wells 299-W11-29 and 299-W11-30. These measurements were used to monitor changes in the water-table elevation. A hydrograph of the water-level data, presented in Figure 5.28, indicates that the water table generally did not change more than about a few hundredths of a meter between November 1992 and August 1993.

Quarterly measurements for water level were collected from a network of approximately 10 wells in the vicinity of the bioremediation demonstration site between 1991 and 1993. These measurements were used to estimate the hydraulic gradient of the water table and general ground-water flow direction at the site. The hydraulic gradient at the site was estimated to be $0.0018,0.0025$, and 0.0021 for December 1991, January 1993, and August 1993, respectively. Water-table maps for these months indicate that ground water is generally flowing from southwest to northeast. A water-table map for August 1993 is presented in Figure 5.29. The best estimate for the direction of ground-water flow is $8^{\circ}$ to $10^{\circ}$ east of a line through wells 299-W11-29 and 299-W11-30. This is based on the water-table map in Figure 5.29, assuming flow is perpendicular to the water-table contours. The ground-water flow direction and gradient at the site is not accurately known because of a lack of a three-point well configuration. 


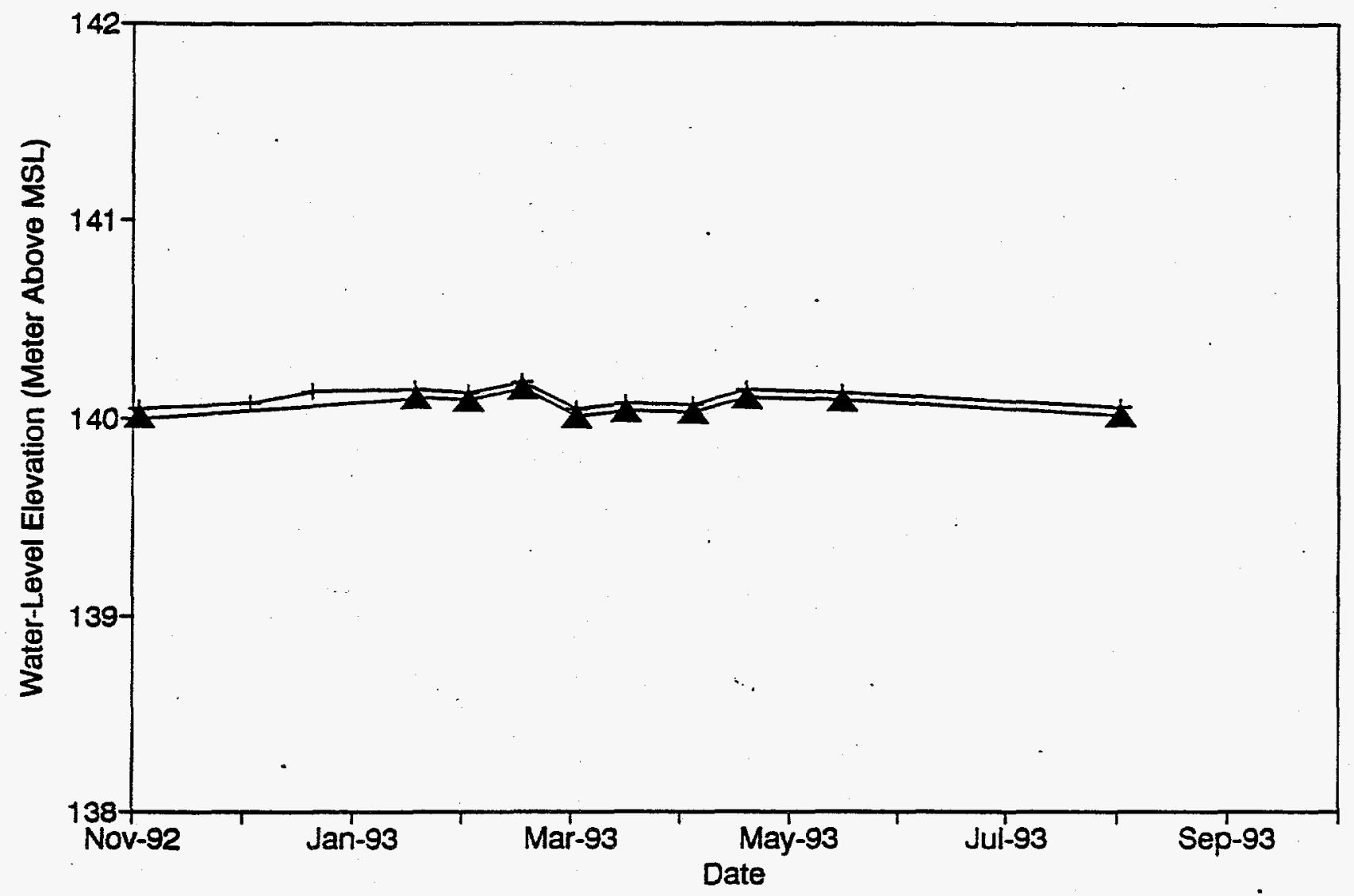

\section{$\rightarrow$ Well 299-W11-29 - Well 299-W11-30}

Figure 5.28. Hydrograph of Wells 299-W11-29 and 299-W11-30 


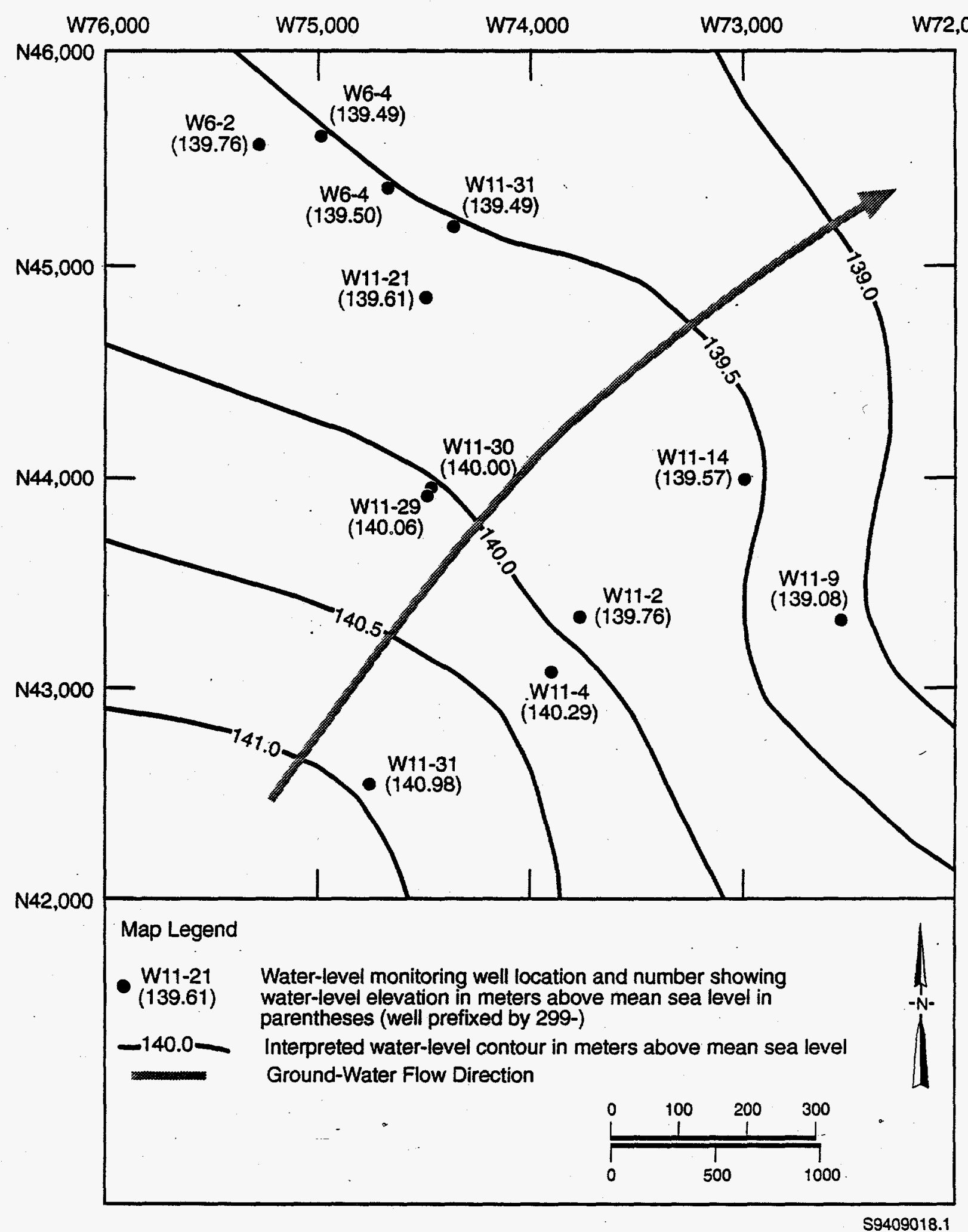

Figure 5.29. Water-Table Map for August 1993 


\subsection{Contaminant Distribution}

Samples were collected and analyzed primarily to determine $\mathrm{CCl}_{4}$ concentration in the solid, aqueous, and gas phase during and after installation of the three wells. All samples were analyzed in a PNL laboratory using a PNL technical procedure, PNL VOA-3, "Volatile Organic Compounds in Water by Purge and Trap Capillary Column Gas Chromatography with Photoionization and Electrolytic Conductivity Detectors in Series," modified from U.S. Environmental Protection Agency (EPA) Method 502.2. Data collected on aqueous concentrations were taken only after the 299-W11-29 and 299-W11-30 wells were installed, and therefore represents an average value for constituent concentration over the entire 9-m (30-ft) screened interval in each well. Only during the installation of well 299-W11-32 were ground-water samples collected during borehole advancement, giving a concentration of $\mathrm{CCl}_{4}$ with depth in the aqueous phase of the saturated zone. In addition, samples were collected from the three isolated screened intervals of well 299-W11-32 after completion, giving further information of contaminant distribution with depth. Sediment samples from all wells were collected during drilling and give information about the constituent distribution with depth in the solid phase of the saturated zone. Gas phase samples were collected only from well 299-W11-32 from the vadose zone sediments above the contact between the upper Ringold and middle units of the Ringold Formation.

\subsection{Gas Phase Contaminant Distribution}

Gas samples were collected using an experimental sampling tool developed at PNL called the Boresampler. The Boresampler is attached to the drilling string and is drilled down into the sediments to collect a gas sample from undisturbed sediments. Sediments that may be sampled with the Boresampler are fine grained, with little consolidation. Samples were collected from sandy sediments of the early "Palouse" soil, Plio-Pleistocene Unit and upper Ringold unit, at five intervals between 29- and 47-m (95- and 155-ft) depth. Gas samples have not been collected successfully from the consolidated gravels of the middle Ringold unit. The $\mathrm{CCl}_{4}$ concentration in the soil gas at the five depths ranged between 1.3 and $27 \mathrm{mg} / \mathrm{L}$ concentration. There was not a distinct trend in the data collected, as shown in Table 6.1.

Table 6.1. Soil Gas Analysis Results for Samples Taken with the Boresampler from Well 299-W11-32

\begin{tabular}{|c|c|c|}
\hline Depth (m) & $\begin{array}{c}\mathrm{CCl}_{4} \\
\text { Concentration } \\
(\mathrm{mg} / \mathrm{L})\end{array}$ & Formation/Unit \\
\hline 30 & 15 & Hanford formation \\
\hline 31 & 5.5 & Early "Palouse" Soil \\
\hline 33 & 3.1 & Early "Palouse" Soil \\
\hline 37 & 27 & Plio-Pleistocene Unit \\
\hline 46 & 1.3 & Upper Ringold Unit \\
\hline
\end{tabular}




\subsection{Solid Phase Contaminant Distribution}

Sediment samples were collected for analyses of VOC concentrations from both the saturated zone and the vadose zone. Samples were collected from the vadose zone only from well 299-W11-32. The results showed that $\mathrm{CCl}_{4}$ was not present in the solid phase vadose zone samples and was present in the solid phase saturated zone samples. The distribution of $\mathrm{CCl}_{4}$ in the saturated sediments ranged between no detection and $300 \mu \mathrm{g} / \mathrm{L}$ in all boreholes sampled.

Sediment samples from well 299-W11-29 showed the highest concentration of $\mathrm{CCl}_{4}$ of any well samples, with $287 \mu \mathrm{g} / \mathrm{L}$ at $257 \mathrm{ft}$ depth (of the sample depths 76,78 , and $80 \mathrm{~m}[248,257$, and $262 \mathrm{ft}$ ), with a concentration range of 10 to $287 \mu \mathrm{g} / \mathrm{L}$. Chloroform was also present in two of the three samples collected, at concentrations of 29 and $103 \mu \mathrm{g} / \mathrm{L}$. Carbon tetrachloride concentration was essentially uniform in depth in the sediments of well 299-W11-30. Concentrations ranged from 193 to $234 \mu \mathrm{g} / \mathrm{L}$ at the 78,83 , and $86 \mathrm{~m}(255,272$, and $281 \mathrm{ft})$ sampled depths, shown in Figure 6.1. Chloroform concentration increased with depth to a maximum of $66 \mu \mathrm{g} / \mathrm{L}$ at the $86-\mathrm{m}(281-\mathrm{ft})$ depth.

Sediment concentrations were measured in the vadose zone and the saturated zone of well 299-W11-32, as shown in Figure 6.2. Carbon tetrachloride was not detected in the vadose zone sediments or those collected near the water table; the first detection was at the 84-m (275-ft) depth $(93 \mu \mathrm{g} / \mathrm{L})$, which is below the water table. The concentration of $\mathrm{CCl}_{4}$ was relatively uniform, except

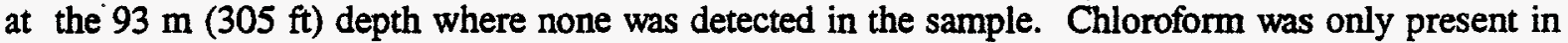
sediments at $91 \mathrm{~m}(300 \mathrm{ft})$ and below; between $91 \mathrm{~m}(300 \mathrm{ft})$ and the bottom of the borehole $(94-\mathrm{m}$ [309-ft] depth), chloroform was present at concentrations that ranged between below the detection limit and $100 \mu \mathrm{g} / \mathrm{L}$.

\subsection{Aqueous Phase Contaminant Distribution}

Ground-water samples were collected from wells 299-W11-29, 299-W11-30, and 299-W11-32 for VOC analyses. Results of analyses from all wells showed the concentration of $\mathrm{CCl}_{4}$ to range between 500 and $3800 \mu \mathrm{g} / \mathrm{L}$ in ground water. Chloroform, when present, is at concentrations between 50 and $750 \mu \mathrm{g} / \mathrm{L}$. VOC concentrations are shown in Figure 6.3 for well 299-W11-29 and Figure 6.4 for well 299-W11-30. Analysis results for samples collected during drilling of well 299-W11-32 are shown in Figure 6.4. VOC concentrations in ground water collected from well 299-W11-32 after completion are shown in Table 6.2 and are plotted in Figure 6.5.

\subsection{Discussion}

Concentrations measured in the solid phase were consistently one to two orders of magnitude lower than ground water sampled from the same interval. The lower values and the fact that $\mathrm{CCl}_{4}$ was not detected in the vadose zone sediments together suggest that there is little sorption of these volatile organics to the sediments. It is more likely that $\mathrm{CCl}_{4}$ detected during sediment analysis was actually in the aqueous phase, collected with the sediment samples. In addition, the volatile nature of these constituents may have influenced the results reported here, as evidenced by the number of sediment samples in which $\mathrm{CCl}_{4}$ was not detected. It is unlikely that more than $50 \%$ of the analyte actually was detected by the analysis equipment, although it is difficult to make a quantitative definition of the actual amount of analyte lost during the sampling and analysis process. 

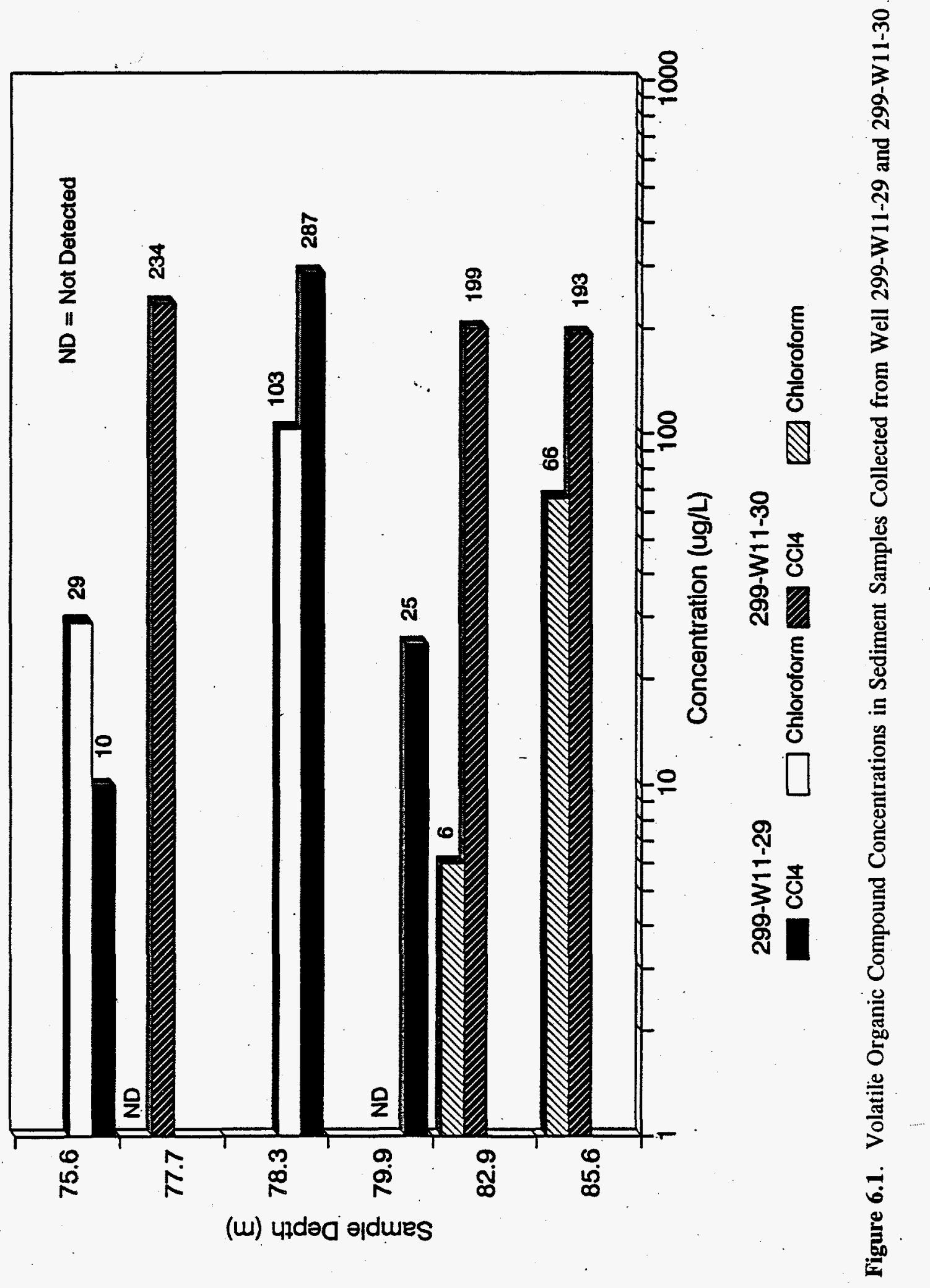


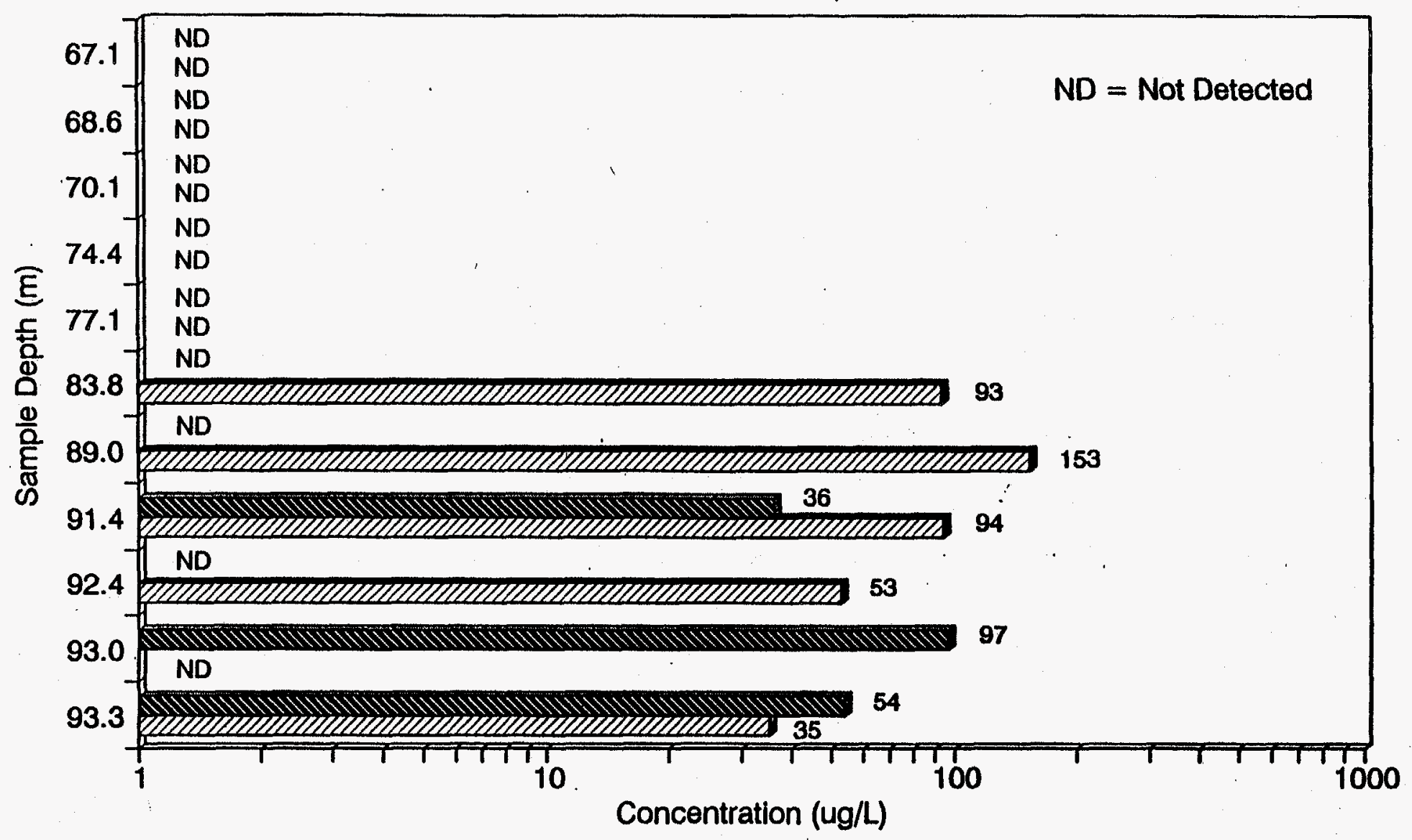

एखI CCl4 $\quad$ Chloroform

Figure 6.2. Volatile Organic Compound Concentrations in Sediment Samples Collected from Well 299-W11-32 


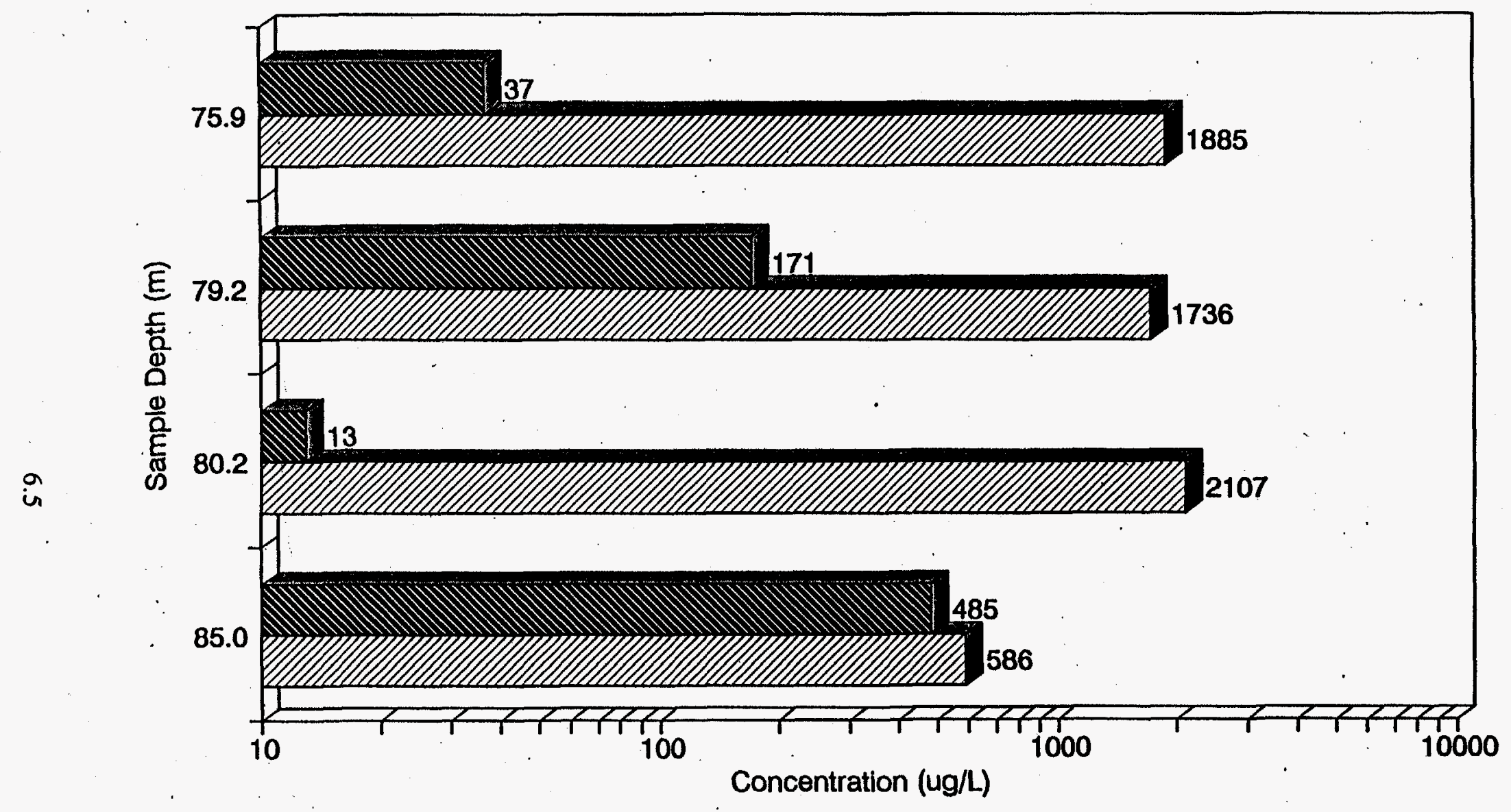

WII CCl4 Chloroform

Figure 6.3. Volatile Organic Compound Concentrations in Ground Water from Well 299-W11-29 


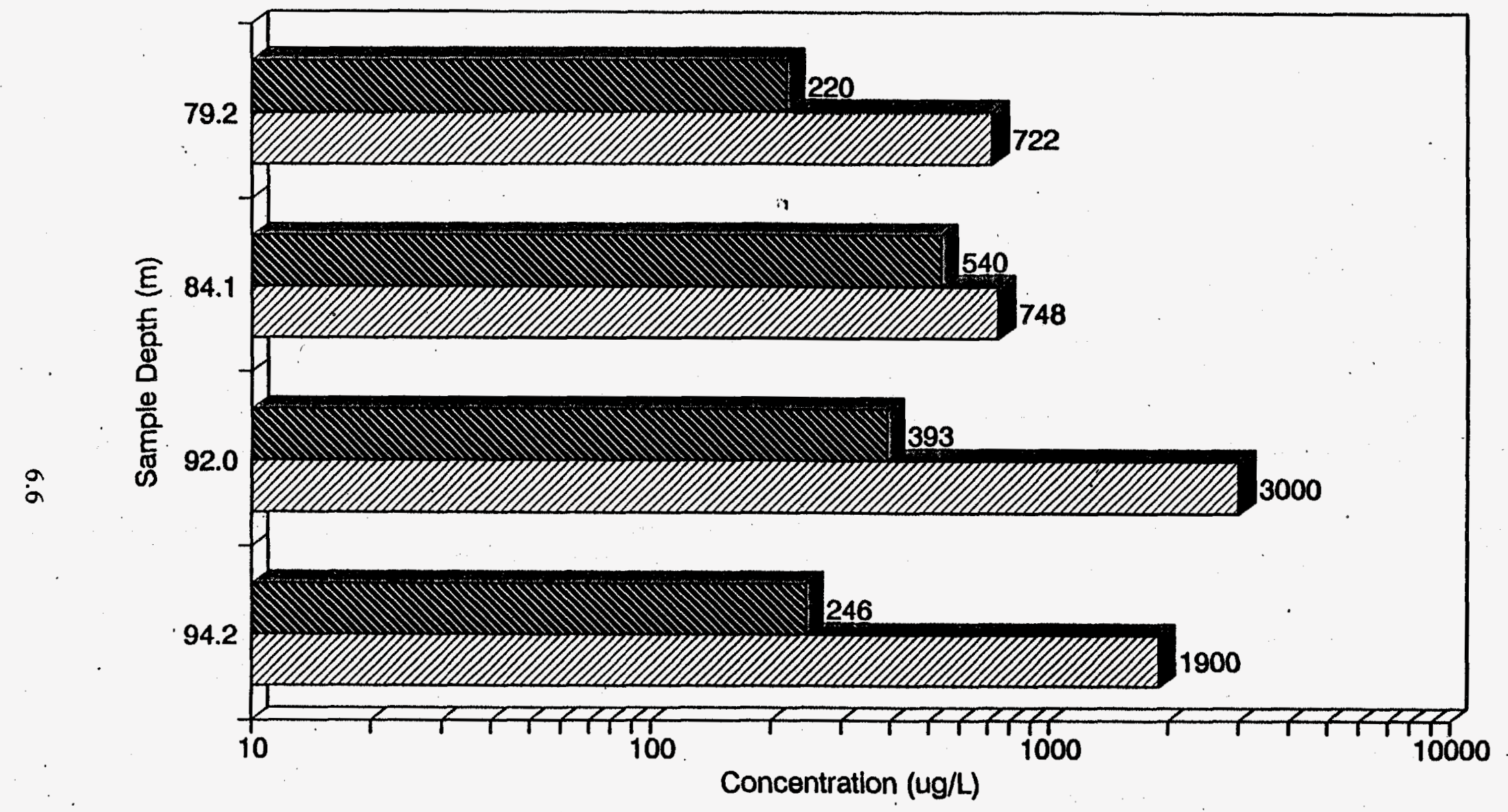

\section{EIIA CCl4 NII Chloroform}

Figure 6.4. Volatile Organic Compound Concentrations in Ground-Water Samples Collected During Drilling Advancement of Well 299-W11-32 


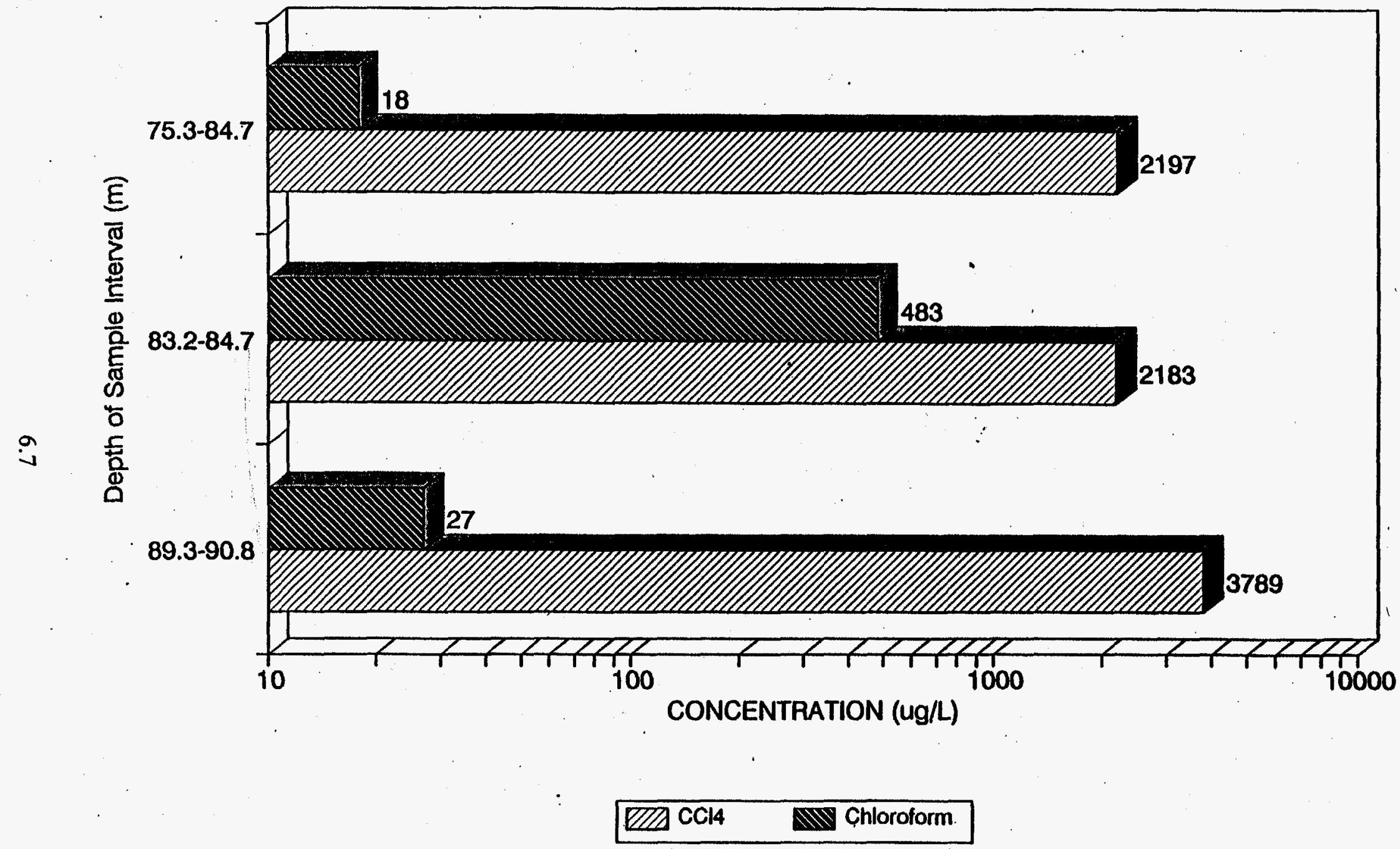

Figure 6.5. Volatile Organic Compound Concentrations in Ground-Water Samples Collected from Well 299-W11-32 After Completion 
Table 6.2. Volatile Organic Compound Concentrations in Ground Water Collected from 299-W11-32 After Completion

\begin{tabular}{|c|c|c|c|}
\hline $\begin{array}{l}\text { Sample Interval } \\
\text { (m) }\end{array}$ & $\begin{array}{c}\mathrm{CCl}_{4} \\
\text { Concentration } \\
(\mu \mathrm{g} / \mathrm{L})\end{array}$ & $\begin{array}{l}\text { Chloroform } \\
\text { Concentration } \\
(\mu \mathrm{g} / \mathrm{L})\end{array}$ & $\begin{array}{c}\text { Trichloroethylene } \\
\text { Concentration } \\
(\mu \mathrm{g} / \mathrm{L})\end{array}$ \\
\hline $75-79$ (Upper) & 2197 & 18 & 28 \\
\hline 83-85 (Middle) & 2183 & 483 & 40 \\
\hline 89-91 (Lower) & 3789 & 27 & 38 \\
\hline
\end{tabular}

The data show that concentrations of $\mathrm{CCl}_{4}$ in ground water vary with depth. However, this distribution may not represent concentrations in the ground water because of the few samples collected. The distribution with depth cannot be statistically determined until more sampling is conducted. Baseline monitoring of $\mathrm{CCl}_{4}$ concentration, with a greater number of samples collected from each of the screened intervals of well 299-W11-32, is planned for FY94. Also, the sample collection technique and analysis procedures are likely to contribute to variations in $\mathrm{CCl}_{4}$ concentration.

Measurements of gas phase samples collected from well 299-W11-32 sediments indicate that the high vapor pressure of $\mathrm{CCl}_{4}$ may allow it to volatilize off the surface of the aquifer into the overlying sediments. Carbon tetrachloride was detected in the gas phase at the contact between the upper and middle Ringold units (a depth of $51 \mathrm{~m}$ [167 ft]) by field screening instruments, a photoionizing detector (PID), an organic vapor analyzer (OVA), and colorimetric tubes. The upward migration of the gas phase from the saturated zone is likely to have been arrested by the finer grained sediments of the upper Ringold unit. Soil gas VOC concentration measurements made using the Boresampler above the upper and middle Ringold unit contact indicate that there is some upward migration of $\mathrm{CCl}_{4}$ in the vapor phase above the upper and middle Ringold unit contact as well.

The field screening instrument measurements on which some of this hypothesis are based do not give quantitative data on gas concentrations in the sediment, rather they are used to indicate the presence of VOCs in the gas phase. Measurement of undisturbed soil gas concentrations below the upper and middle Ringold unit contact was not possible using the Boresampler. As mentioned previously, this sampling tool is not effective at collecting soil gas samples from the gravelly, wellcemented sediments, like those that make up the middle Ringold unit. The soil gas concentrations determined using soil gas samples collected with the Boresampler show that flux is continuing above the upper and middle Ringold unit contact. However, there is not enough data available to assess the flux rate or volume of vapor phase $\mathrm{CCl}_{4}$ above the water table or through the upper and middle Ringold unit contact. 


\subsection{Ground-Water Chemistry}

Ground-water sample analyses and in situ measurements were conducted to determine the background water chemistry conditions of the upper part of the aquifer. Most of the collected samples were analyzed by DataChem, Salt Lake City, Utah. Some of the samples were analyzed by PNL, Richland, Washington, during the early part of the sampling program. Samples were analyzed for general water chemistry parameters, anions, cations, and total organic carbon. Ground-water samples were collected both during drilling and after well completion from various depths below the water table.

\subsection{Water Chemistry Parameters}

A HydroLab in situ probe was used to measure hydrochemical ground-water parameters during construction and after development of well 299-W11-32. Results of the measurements, which include temperature, $\mathrm{pH}$, specific conductance (SC), total dissolved solids (TDS), dissolved oxygen (DO), and redox potential (Eh), are shown in Table 7.1. The data indicate similar results for measurements taken during well construction in August 1993 and after development in October 1993.

Total dissolved solids measured in well 299-W11-32 are within the range expected for most ground waters, indicating good water quality. Total dissolved solids represent the total sum of dissolved constituents and the total amount of solids remaining after a sample is dried. Specific conductance, a measurement of electrical conductivity, ranges between 692 and $886 \mathrm{mS} / \mathrm{cm}$. Measured ion concentrations, discussed in the following section, are consistent with TDS and SC measured by the in situ probe.

For the August 9, 1993, sample date, the DO and Eh readings stabilized after steadily dropping during the course of the measurement. Therefore, the latter values, shown in Table 7:1, are most representative. Oxygen may have been introduced to the sample ground water during insertion of the in situ probe. Furthermore, the probe was placed in the water for a longer period of time than for the October 29, 1993, measurements. Consequently, these readings are most representative of stable ground-water conditions. During the October measurements, Eh readings actually rose while DO dropped. The rise in Eh may be a consequence of the measurement procedure.

Table 7.1. Hydrochemical Parameters Measured in Well 299-W11-32

\begin{tabular}{|c|c|c|c|c|c|c|c|c|c|}
\hline $\begin{array}{r}\text { Depth } \\
\text { (ft bls) }\end{array}$ & Date & Time & $\begin{array}{c}\text { Temp. } \\
{ }^{\circ} \mathrm{C}\end{array}$ & $\mathrm{pH}$ & $\begin{array}{c}\mathrm{SC} \\
(\mathrm{mS} / \mathrm{cm})\end{array}$ & $\begin{array}{c}\text { TDS } \\
(\mathrm{mg} / \mathrm{L})\end{array}$ & $\begin{array}{c}\text { DO } \\
\% \text { Sat. }\end{array}$ & $\begin{array}{c}\mathrm{DO} \\
(\mathrm{mg} / \mathrm{L})\end{array}$ & $\begin{array}{c}\mathrm{Eh} \\
(\mathrm{mV})\end{array}$ \\
\hline 254 & $08 / 04 / 93$ & 0840 & 19.7 & 7.72 & 0.692 & 443 & 47.8 & 4.29 & 235 \\
\hline 300 & $10 / 29 / 93$ & 1010 & 19.1 & 7.33 & 0.885 & 566 & 79.9 & 7.41 & 343 \\
\hline 277 & $10 / 29 / 93$ & 1043 & 19.1 & 7.32 & 0.882 & 564 & 62.9 & 5.83 & 355 \\
\hline 254 & $10 / 29 / 93$ & 1105 & 19.0 & 7.35 & 0.886 & 567 & 51.2 & 4.76 & 357 \\
\hline
\end{tabular}


The data indicate that DO content is depressed, approximately half of saturation (measured at 4.29 to $4.76 \mathrm{mg} / \mathrm{L}$ between $19.0^{\circ}$ and $19.7^{\circ} \mathrm{C}$. The Eh measurements, ranging between 235 and $357 \mathrm{mV}$, indicate oxidizing conditions. The high proportion of ferric iron ( $\mathrm{Fe}^{3+}$ ) to total iron measured in sediment and ground water also supports oxidizing conditions. These conditions are consistent with unconfined ground-water conditions observed at other locations at the Hanford Site.

\subsection{Anions and Cations}

Ground-water samples collected at various depths during drilling and after completion and development of wells 299-W11-30 and 299-W11-32 were analyzed for anions and cations. Groundwater samples collected from well 299-W11-29 were collected only during drilling. All anions were analyzed using ion chromatography. Metals in ground water were analyzed using ICP atomic emission. There is some variability in the types of metal cations analyzed for each well. Results from post-development samples will mostly be discussed here because of the uncertainty associated with the quality of the samples collected during drilling.

The major hydrochemical constituents in ground water at the in situ bioremediation site are summarized in Table 7.2. The analysis results for anions are presented as bar-graphs in Figures 7.1 and 7.2. The results indicate that nitrate has, by far, the highest concentration, ranging between 220 and $350 \mathrm{mg} / \mathrm{L}$. These concentrations are consistent with nitrate concentrations observed in adjacent areas of the 200-West Area (Dresel et al. 1993). Nitrate at the in situ bioremediation site is associated with a nitrate contaminant plume in the north-central and northeastern portion of the 200-West Area. Figure 7.2 indicates little variability in concentration with depth.

Table 7.2. Average Results of Major Hydrochemical Ground-Water Constituents Measured from Wells 299-W11-30 and 299-W11-32

\begin{tabular}{lccc}
\cline { 1 - 2 } Major Constituents & Well 299-W11-30 & Well 299-W11-32 \\
\cline { 1 - 1 } $\mathrm{pH}$ & & 7.56 & 7.34 \\
Alkalinity $\left(\mathrm{HCO}_{3}{ }^{-}\right)$ & & 130 & - \\
$\mathrm{Cl}^{-}$ & 21 & 24 \\
$\mathrm{NO}_{3}^{-}$ & 285 & 270 \\
$\mathrm{SO}_{4}{ }^{2-}$ & 66 & 55 \\
$\mathrm{Ca}^{2+}$ & 91 & 90 \\
$\mathrm{~K}^{+}$ & 5.9 & 6.1 \\
$\mathrm{Mg}^{2+}$ & 30 & 31 \\
$\mathrm{Na}^{+}$ & 21 & 36
\end{tabular}

Note: All values in units of $\mathrm{mg} / \mathrm{L}$ except $\mathrm{pH}$. 


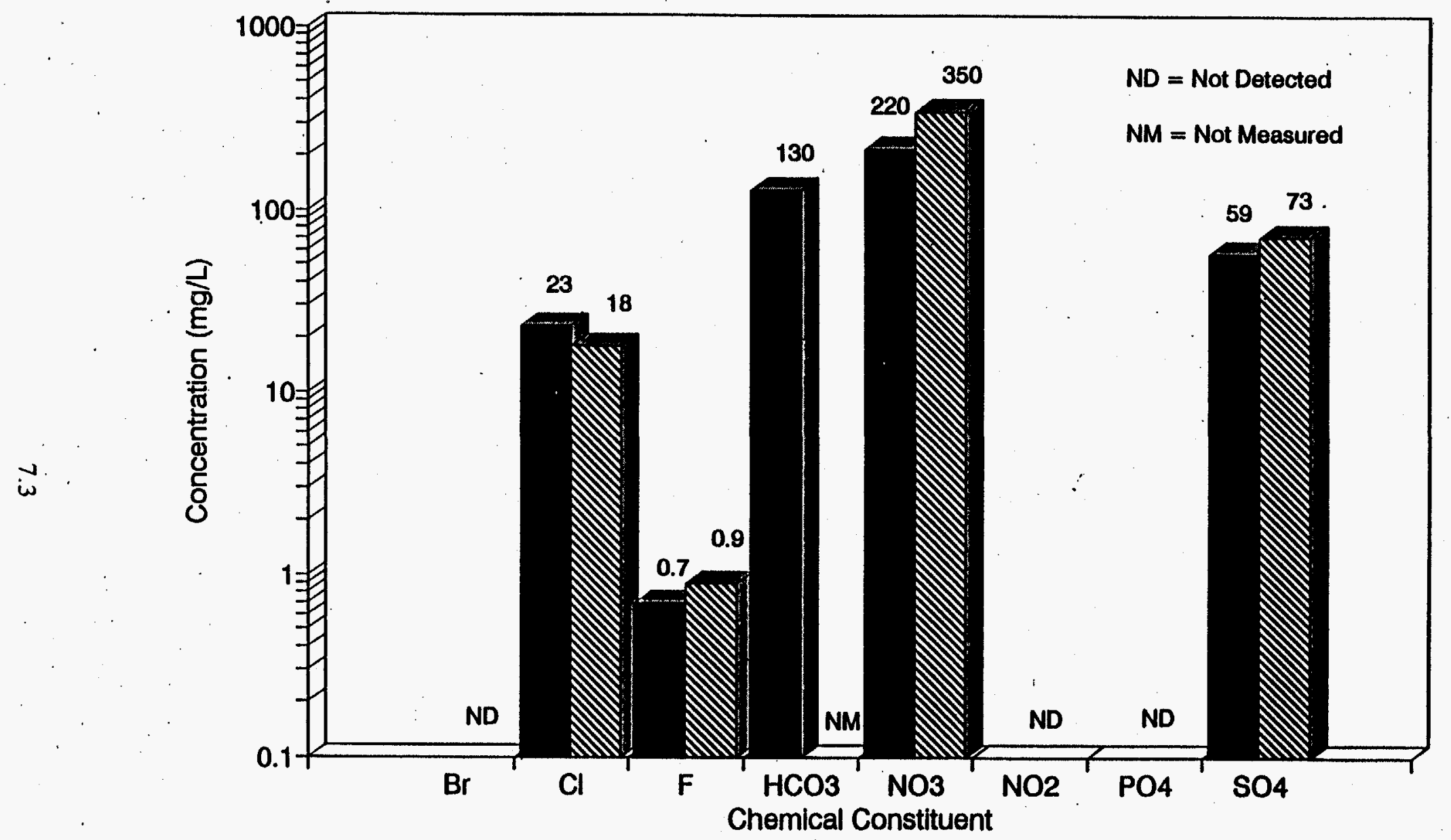

Sampled 5/13/92 Sampled 12/28/92

Figure 7.1. Anions Analysis for Well 299-W11-30 


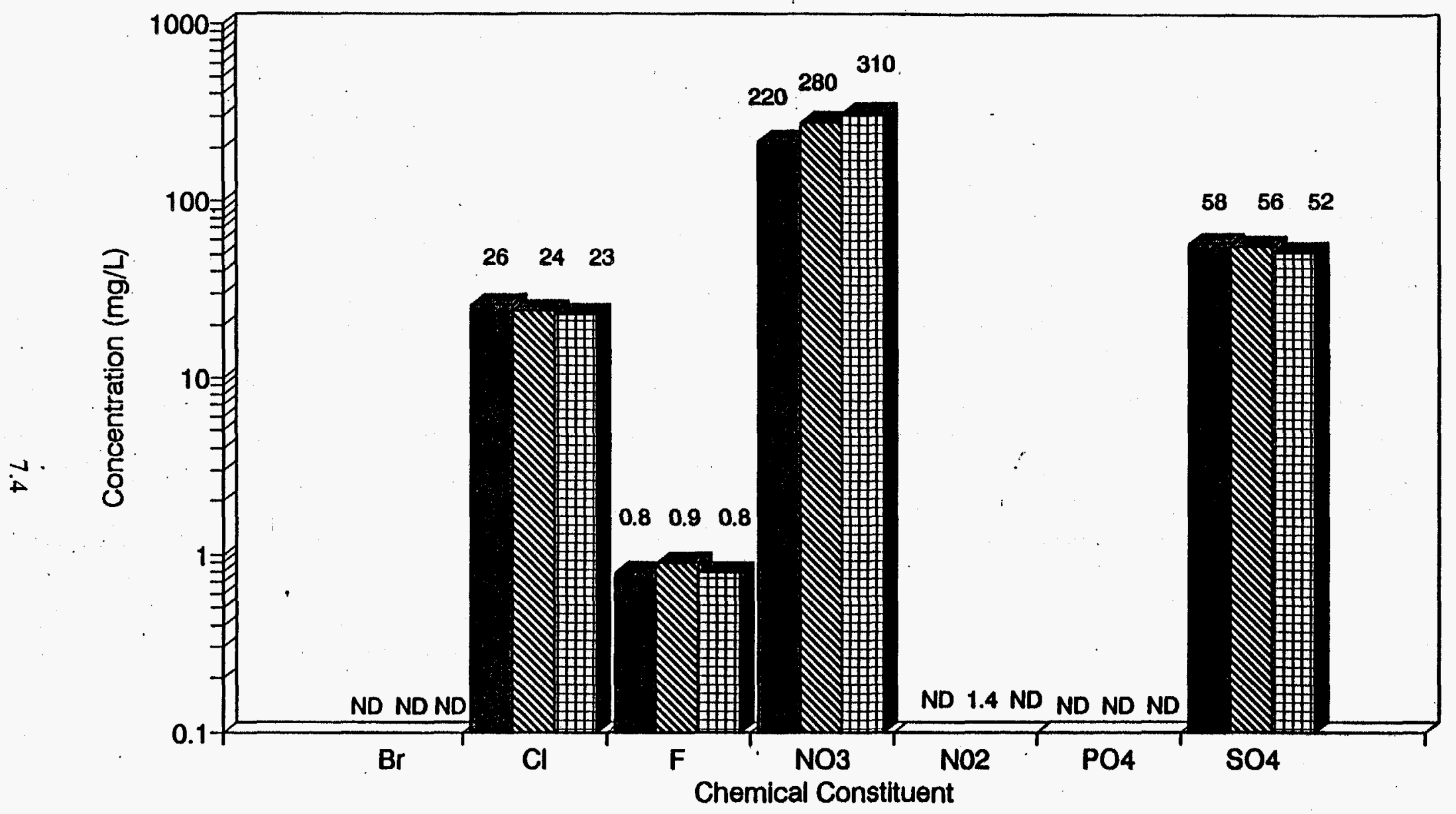

Top Screen Middle Screen Bottom Screen

Figure 7.2. Anions Analysis Results for the Three Screened Intervals of Well 299-W11-32 
Bicarbonate, sulfate, and chloride, the next most predominant anion constituents, were $130 \mathrm{mg} / \mathrm{L}$, between 52 and $73 \mathrm{mg} / \mathrm{L}$, and between 18 and $26 \mathrm{mg} / \mathrm{L}$, respectively. Bicarbonate is measured as $\mathrm{mg} / \mathrm{L}$ of calcium carbonate $\left(\mathrm{CaCO}_{3}\right)$ from an alkalinity titration with a ground-water $\mathrm{pH}$ of 7.55. Sulfate, chloride, and fluoride were detected above the background concentrations reported by Evans et al. (1989). Nitrite, detected in only some of the samples, had a very low concentration. However, $10 \mathrm{mg} / \mathrm{L}$ of nitrite was detected from a sample collected during drilling. The presence of sulfate is common for ground water moving through silt-, clay-, or shale-bearing aquifers. The chemical alteration of the clay and silt portions of the sediments, discussed in the section on sediment chemistry, contributes these ions to ground water. Bromide and phosphate were not detected in any of the samples collected.

Bar graphs showing the metal concentrations for samples collected after well development are presented in Figures 7.3 and 7.4. Concentrations were consistently high for many of the metal ions analyzed. Calcium is the most dominant cation present, with concentrations ranging between $85 \mathrm{mg} / \mathrm{L}$ and $96 \mathrm{mg} / \mathrm{L}$. Other metals present with consistent high concentrations include iron, magnesium, manganese, potassium, and sodium. The primary source of calcium, magnesium, potassium, and sodium in ground water is dissolution of minerals that make up the fine-grained sediments. Manganese, aluminum, copper, zinc, and barium ions are present in higher concentrations than expected from dissolution. Aluminum and iron at these concentrations would be expected to occur under very low pH conditions (e.g., $\mathrm{pH}<4$ ). The high chromium concentrations are associated with a complex chromium plume that exists near the T Plant area (Dresel et al. 1993).

Samples collected during drilling may not be representative of the ground-water chemistry. The results in Figures 7.5 and 7.6 indicate that samples collected during drilling generally have higher concentrations than samples collected after well completion and development. Some of these higher concentrations may be a result of suspended sediment in the samples taken during drilling. Sediment is removed from the borehole during development and therefore is minimized during subsequent sample collection. Also, manganese, aluminum, copper, and iron may be a product of the drilling process. The drilling tools may release metals to ground water during contact with the sediments.

\subsection{Total Organic Carbon}

Ground-water samples were collected for total organic carbon (TOC) analysis at four depths during drilling of well 299-W11-32. The TOC content of a sample refers to both the dissolved and particulate organic carbon. The results indicate that the TOC content ranged between 0.5 and $2.0 \mathrm{mg} / \mathrm{L}$. The difference between the $2.0-\mathrm{mg} / \mathrm{L}$ value and the remaining samples analyzed suggests that the $2.0-\mathrm{mg} / \mathrm{L}$ sample was contaminated by an unknown source or process. Although all the samples were collected with the same sampling tools and the tools were cleaned using the same method, the difference between the TOC values is likely due to variations in the sample collection technique. 


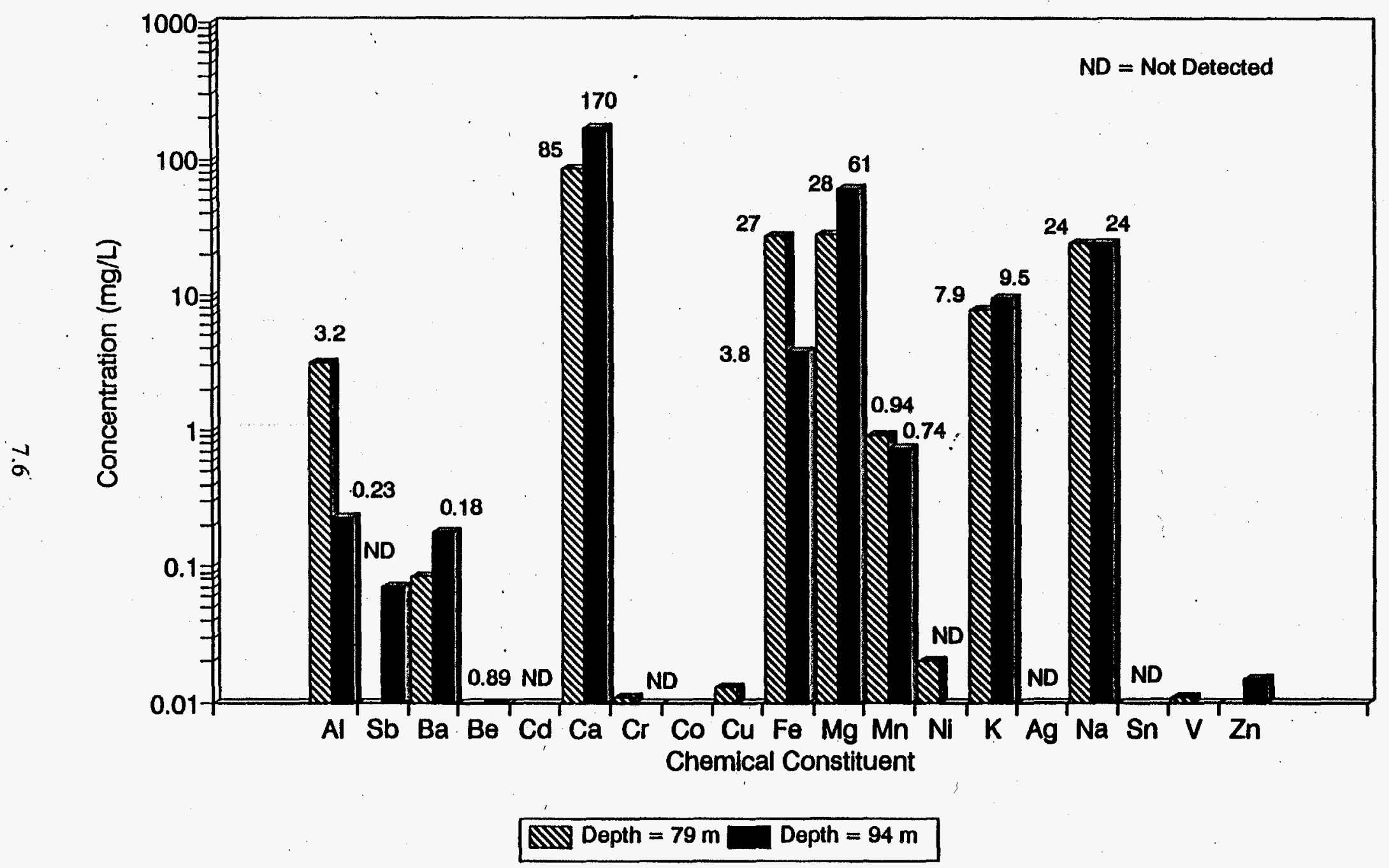

Figure 7.3. Metals Analysis Results for Well 299-W11-30 


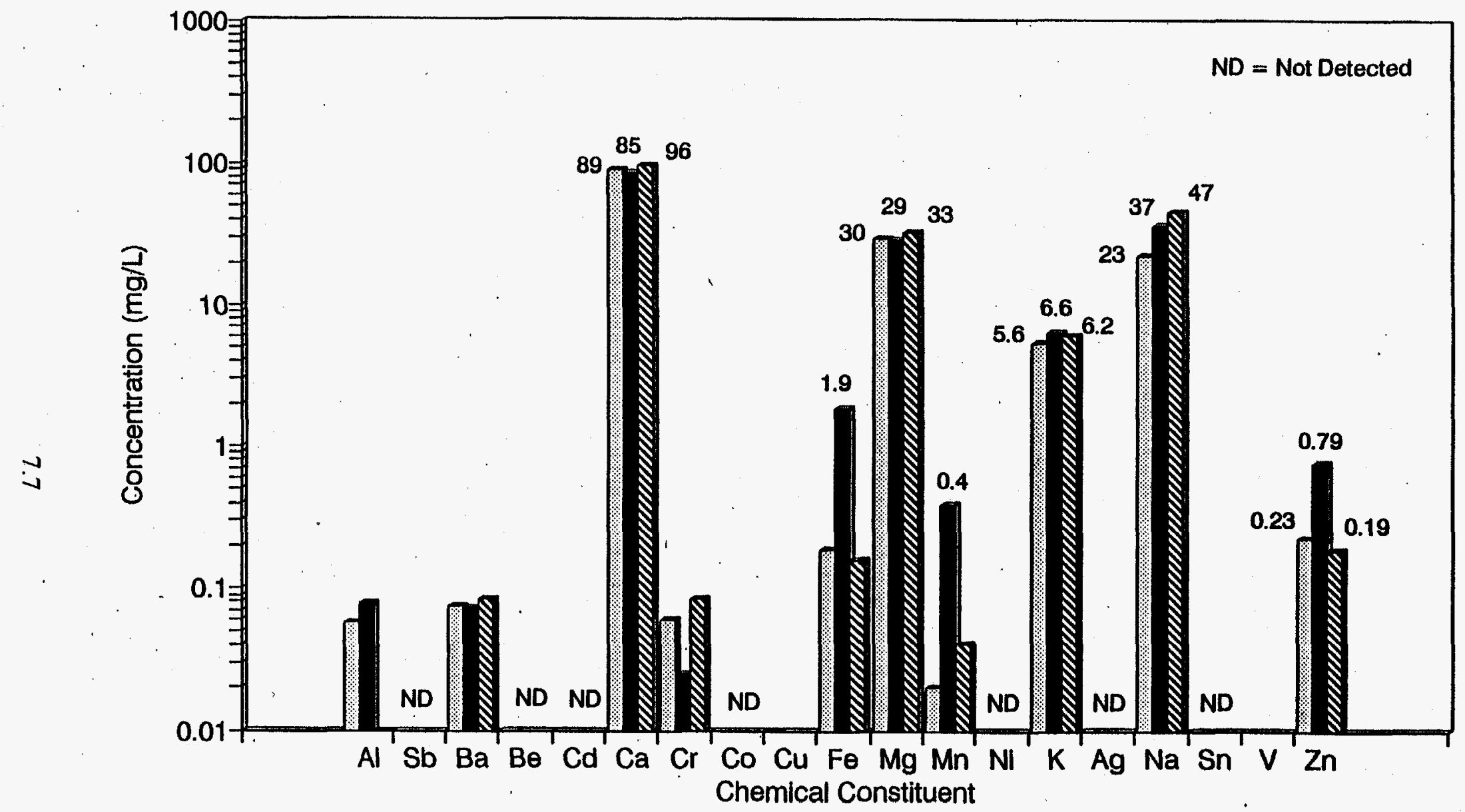

\section{Top Screen Middle Screen Bottom Screen}

Figure 7.4. Metals Analysis Results for the Three Screened Intervals of Well 299-W11-32. 


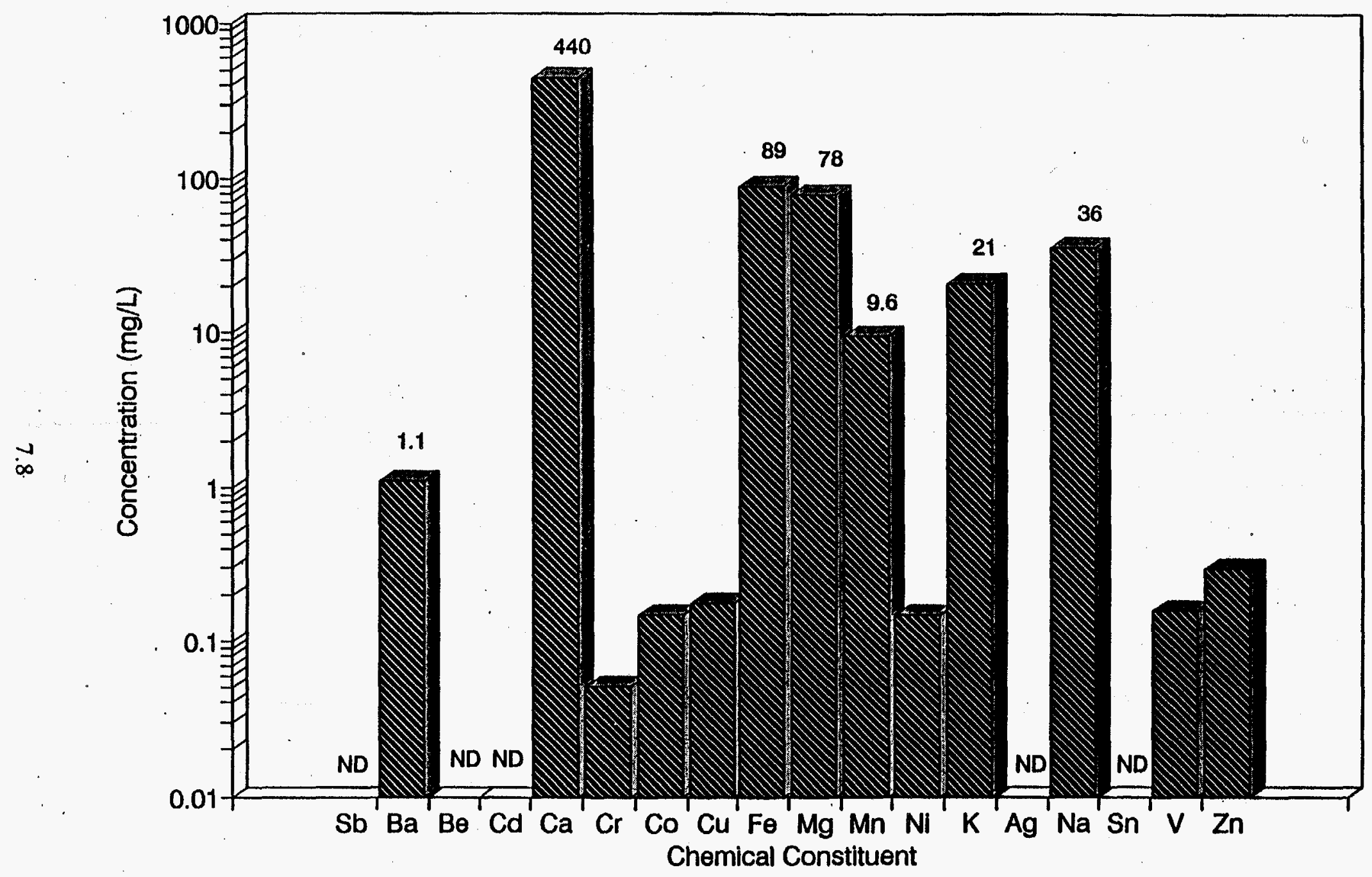

Figure 7.5. Metals Analysis Results for Samples Collected at a Depth of $82 \mathrm{~m}$ (268 ft) During Drilling Advancement of Well 299-W11-30 


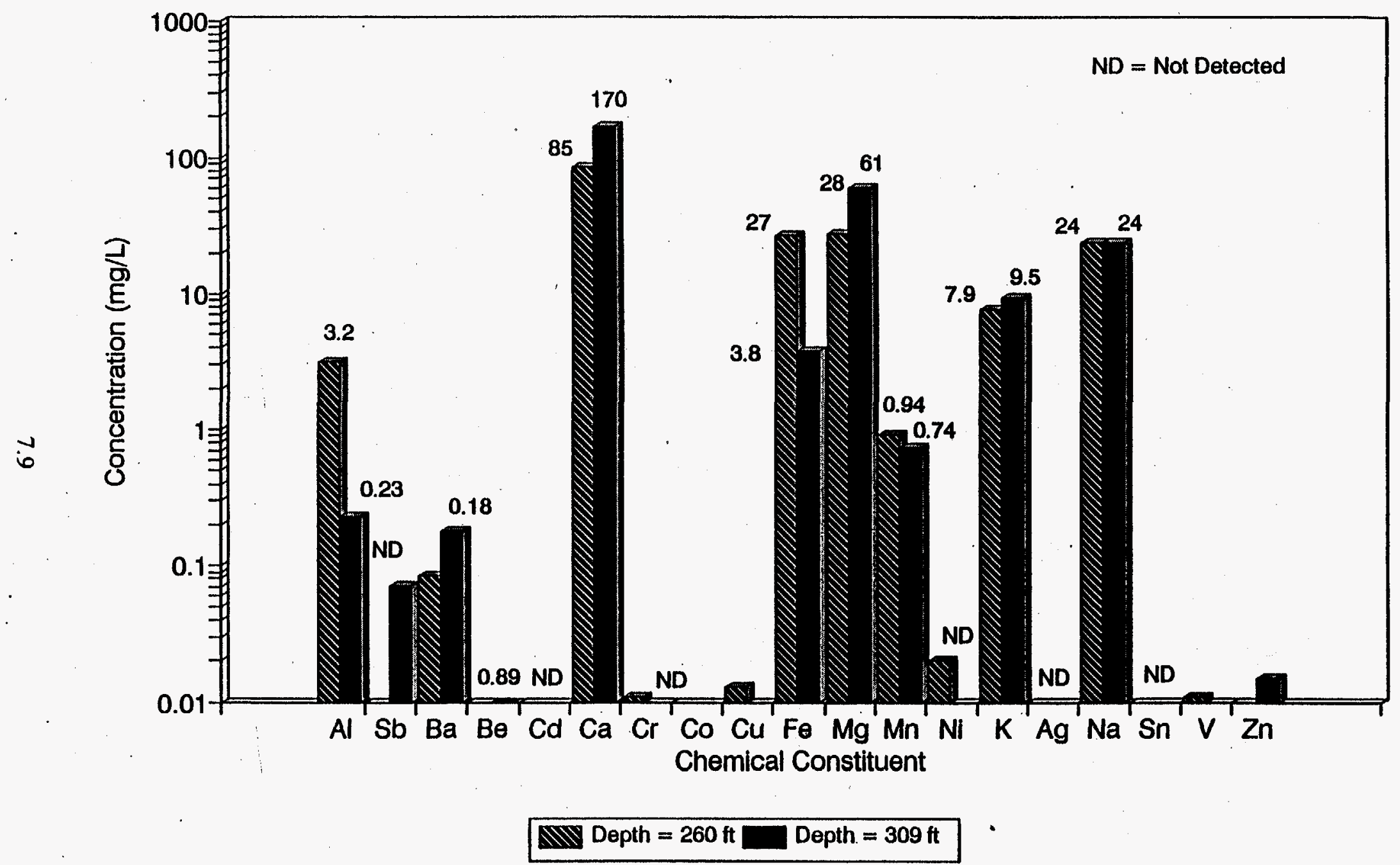

Figures 7.6. Metals Analysis Results for Samples Collected During Drilling Advancement of Well 299-W11-32 


\subsection{Microbiological Characterization}

A series of microbiological analyses have been performed to determine the number and types of microorganisms at depth within and just above the aquifer. The analyses were performed on core samples that were collected from well 299-W11-32 at depths of 73, 76, 82, 88, and $92 \mathrm{~m}(241,248$, 268, 289, and $303 \mathrm{ft}$ ). Current data include plate counts of aerobic heterotrophs and most probable number (MPN) for denitrifying bacteria tests.

The following data are from the plate count of aerobic heterotrophs. Serial dilutions of the sediment were performed $\left(10^{-2}\right.$ to $\left.10^{-5}\right)$, and media plates of Optimal Plate Count Agar (Stevens et al. 1992) were spread with $0.1 \mathrm{~mL}$ of the respective dilutions in triplicates (APHA 1989). Also, a set of plates were sprinkled with the sediment as a minimal dilution treatment. Six colony types were observed (yellow, white, translucent, uneven, even, and punctiform). The colony forming unit (CFU) per gram of soil was obtained at various depths and shown in Table 8.1.

No microbes were enumerated using the techniques in this investigation from the 73-m (241-ft) sample. This sample was collected from the unsaturated zone where microbial activity is typically much lower than for saturated sediments because of low water and nutrient availability. A significant microbial activity ( $10^{6} \mathrm{CFU} / \mathrm{g}$ of soil) was observed in saturated sediments at depths of 76 and $82 \mathrm{~m}$ (248 ft and $268 \mathrm{ft})$. The sample collected at $88 \mathrm{~m}(289 \mathrm{ft})$ had a very low microbial activity. Growth was seen only in sprinkle plates with colonies having an actinomyces type of morphology. This sample was collected from a sandy layer just below the well-cemented, low permeable layer identified at a nominal depth interval of 84 to $87 \mathrm{~m}$ (277 to $285 \mathrm{ft}$ ). The microbial activity at $92 \mathrm{~m}(303 \mathrm{ft})$, however, was on the order of magnitude of $10^{6} \mathrm{CFU} / \mathrm{g}$ of soil. It is not known at this time whether this discrepancy is an enumeration anomaly or a real difference from different sediment type, nutrient flux, or other in situ conditions at this depth interval. Additional samples will be taken during drilling of wells planned for late FY94.

The following data correspond to the MPN (APHA 1989; section 3.3.3.1) of denitrifying bacteria. Media tubes were inoculated with $1 \mathrm{~mL}$ of $10^{-2}$ to $10^{-5}$ dilutions in triplicate $\left(10^{-4}\right.$ to $10^{-7}$ dilutions

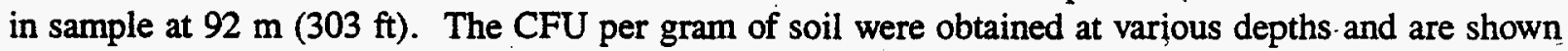
in Table 8.2.

Table 8.1. Results of CFU Data for Aerobic Heterotrophs from Various Sample Depths

\begin{tabular}{cl} 
Depth (m) & CFU aerobic heterotrophs/g of soil \\
\hline 73 & $<1 \mathrm{E} 2$ \\
76 & $1.16 \mathrm{E} 6 \pm 2.75 \mathrm{E} 5$ \\
82 & $1.43 \mathrm{E} 6 \pm 9.03 \mathrm{E} 5$ \\
88 & $<1 \mathrm{E} 2$ \\
92 & $1.44 \mathrm{E} 6 \pm 1.35 \mathrm{E} 5$
\end{tabular}


Table 8.2. Results of CFU Data for Denitrifying Bacteria from Various Sample Depths

\begin{tabular}{cc} 
Depth (m) & CFU denitrifiers/g of soil \\
\hline 73 & $<1 \mathrm{E} 2$ \\
76 & $>2.40 \mathrm{E} 5$ \\
82 & $>2.40 \mathrm{E} 5$ \\
88 & $<1 \mathrm{E} 2$ \\
92 & $2.10 \mathrm{E} 6$
\end{tabular}

The numbers (CFU/g of soil) obtained in the heterotroph plate count and denitrifier MPN demonstrated a correlation between these two tests. Because denitrifiers like Pseudomonads are widespread in nature, it may be inferred from this correlation that facultative denitrifiers are predominant at this site.

Additional microbial enumeration data were obtained during drilling operations for well 299-W11-29. Numbers of denitrifiers were determined using the MPN technique as described for well 299-W11-32 samples. In all saturated sediments, there were greater than 1E4 denitrifiers per gram of sediment. 


\subsection{Conclusions}

Comparative data interpreted from geologic samples, geophysical logging, and hydrologic testing are shown in Figure 9.1. The data indicate that properties of the aquifer formation vary with depth. The single variation with depth is the degree of consolidation of the sediments. Sediment consolidation was caused by cementation, compaction, and secondary chemical alteration. Two fairly distinct porous zones exist within the upper part of the aquifer that was penetrated at the site. These zones lie at depths of approximately 75 to $78 \mathrm{~m}(247$ to $256 \mathrm{ft}$ ) and 88 to $91 \mathrm{~m}(288$ to $298 \mathrm{ft})$. The upper porous zone is laterally continuous between the three wells drilled. A minor, but distinct, porous zone also occurs at a depth of 82 to $84 \mathrm{~m}$ (268 to $274 \mathrm{ft}$ ). The degree of consolidation of the sediments appears to be the most significant factor in the variation of hydraulic properties with depth.

From hydraulic testing results, the horizontal hydraulic conductivity varied up to an order of magnitude with depth, the highest values approximately corresponding with the two distinct porous zones. The tracer test results, in conjunction with hydraulic pumping test results, also indicate variations in horizontal hydraulic properties with depth. Local variations in vertical hydraulic properties, as measured by laboratory hydraulic conductivity, ranged up to three orders of magnitude.

Based on concentration data from both the vadose and saturated zone, it is suggested that most, if not all, of the $\mathrm{CCl}_{4}$ detected is representative of the aqueous phase. Carbon tetrachloride gas was detected in the vadose zone, suggesting volatilization and subsequent upward migration from the saturated zone. Water chemistry parameter results and a high proportion of $\mathrm{Fe}^{3+}$ to total iron in sediment indicate oxidizing conditions. The results also indicate that nitrate, associated with a nitrate contaminant plume in the 200 -West Area is, by far, the most dominant constituent present. 


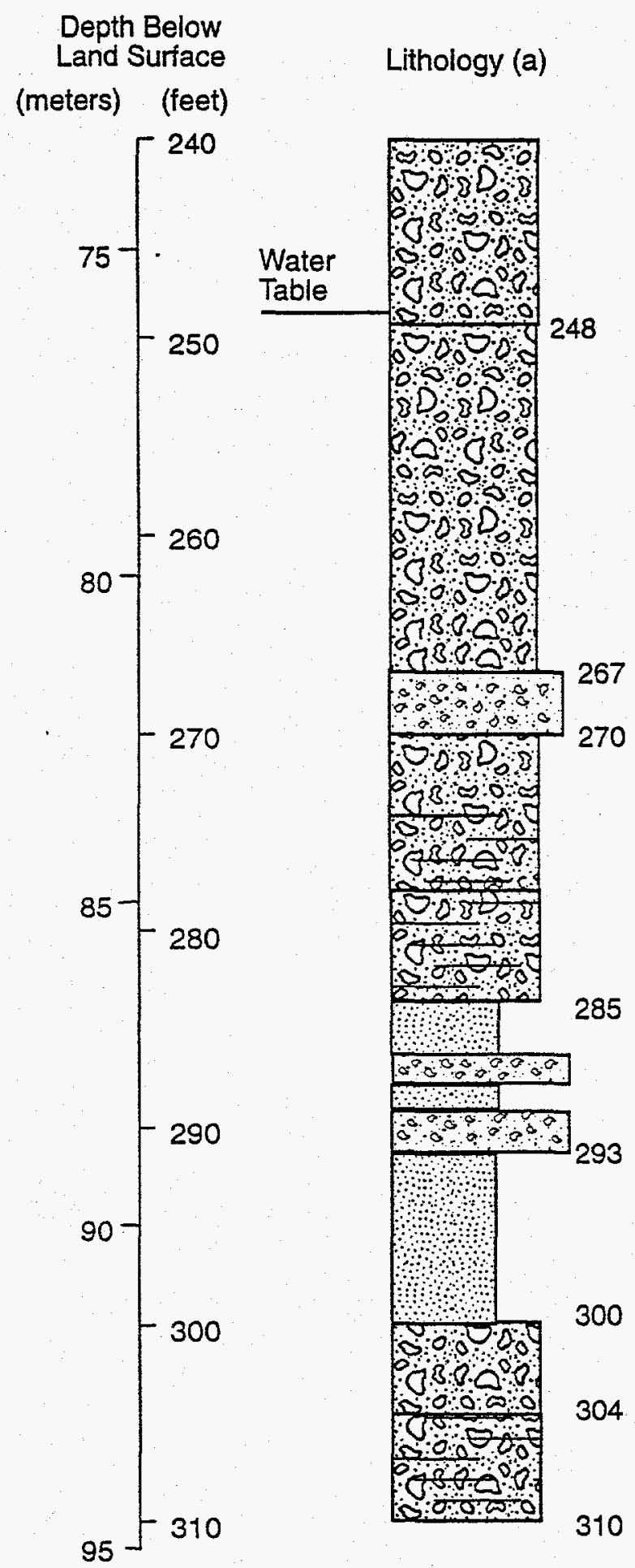

Muddy Sandy Gravel (cemented)

Muddy Sandy Gravel

Sandy Gravel (poorly consolidated)

Muddy Sandy Gravel

\Well-Cemented and Chemically Altered at 277 to $285 \mathrm{ft}$

Interlayered Sand and Sandy Gravel

Sand

Chemically Altered at 296 to $300 \mathrm{ft}$

Muddy Sandy Gravel (cemented)

Muddy Sandy Gravel (well-cemented and chemically altered)
Well

Inten

Well
$\# 29$

主

怣

273

278

93

298

08

(a) Lithologic descriptions correspond to intervening depths shown except where noted

Figure 9.1. Summary of Site Characterization Info 


\subsection{References}

Agarwal, R. G. 1980. "A New Method to Account for Producing Time Effects when Drawdown Type Curves are Used to Analyze Pressure Buildup and Other Test Data." Presented at the 1980 Society of Petroleum Engineers Annual Technical Conference and Exhibition, Dallas. SPE Paper 9289.

American Public Health Association (APHA). 1989. Standard Methods for Examination of Water and Wastewater. 17th Edition. American Public Health Association, Washington, D.C.

Bjornstad, B. N. 1990. Geohydrology of the 218-W-5 Burial Ground, 200-West Area, Hanford Site. PNL-7336, Pacific Northwest Laboratory, Richland, Washington.

Bjornstad; B. N., K. R. Fecht, and A. M. Tallman. 1987. Quaternary Stratigraphy of the Pasco Basin, South-Central Washington. RHO-BW-563A, Rockwell Hanford Operations, Richland, Washington.

Bouwer, H. 1989. "The Bouwer and Rice Slug Test - An Update." Ground Water 27(3):304-309.

Bouwer, H., and R. C. Rice. 1976. "A Slug Test for Determining Hydraulic Conductivity of Unconfined Aquifers With Completely or Partially Penetrating Wells." Water Resources Research $12(3): 423-428$.

Brownlow, A. H. 1979. Geochemistry. Prentice-Hall, Inc., Englewood Cliffs, New Jersey.

Chapelle, F. H. 1993. Ground-Water Microbiology and Geochemistry. John Wiley and Sons, New York.

Clark, W. E. 1967. "Computing the Barometric Efficiency of a Well." In Proceedings of the American Society of Civil Engineers, Journal of the Hydraulics Division 43(HY4):93-98.

Connelly, M. P., B. H. Ford, and J. V. Borghese. 1992. Hydrogeologic Model for the 200 West Groundwater Aggregate Area. WHC-SD-EN-TI-014, Rev. 0, Westinghouse Hanford Company, Richland, Washington.

Cooper, H. H., Jr., and C. E. Jacob. 1946. "A Generalized Graphical Method for Evaluating Formation Constants and Summarizing Well-Field History." Amer. Geophysical Union 27(4):526-534.

Dresel, P. E., D. R. Newcomer, J. C. Evans, W. D. Webber, F. A. Spane, Jr., R. G. Raymond, and B. E. Opitz. 1993. Hanford Site Ground-Water Monitoring for 1992. PNL-8716, Pacific Northwest Laboratory, Richland, Washington.

Evans, J. C., R. W. Bryce, D. R. Sherwood, M. L. Kemner, and D. R. Newcomer. 1989. Hanford Site Ground-Water Monitoring for July Through December 1988. PNL-7120, Pacific Northwest Laboratory, Richland, Washington. 
Folk, R. L. 1968. Petrology of Sedimentary Rocks. University of Texas, Austin, Texas.

Follett, E. A. C., W. J. McHardy, B. D. Mitchell, and B. F. L. Smith. 1965. "Chemical Dissolution Techniques in the Study of Clays." Clay Mineralogy 6:23-43.

Gephart, R. E., R. C. Arnett, R. G. Baca, L. S. Leonhart, and F. A. Spane, Jr. 1979. Hydrologic Studies Within the Columbia Plateau, Washington: An Integration of Current Knowledge.

RHO-BWI-ST-5, Rockwell Hanford Operations, Richland, Washington.

Gorby, Y. A., D. W. Kennedy, A. E. Plymale, and J. E. Amonette. 1994. "Transformation of Carbon Tetrachloride by an Iron Reducing Bacterium in the Presence of Solid Phase Iron." Abstract of paper presented at General Meeting of the American Society for Microbiology, May 23-27, 1994, Las Vegas, Nevada, PNL-SA-23514, Pacific Northwest Laboratory, Richland, Washington.

Govett, G. J. S. 1961. "Critical Factors in the Colorimetric Determination of Silica." Anal. Chim. Acta 25:69-80.

Hall, S. H., S. P. Luttrell, and W. E. Cronin. 1991. "A Method for Estimating Effective Porosity and Ground-Water Velocity." Ground Water 29(2):171-174.

Hall, S. H. 1993. "Single Well Tracer Tests in Aquifer Characterization." Ground Water Monitoring and Remediation 13(2):118-124.

Jacob, C. E. 1940. "On the Flow of Water in an Elastic Artesian Aquifer." American Geophysical Union Transactions 14:446-460.

Komadel, P., and J. W. Stucki. 1988. "Quantitative Assay of Minerals for $\mathrm{Fe}+$ and $\mathrm{Fe} 3+$ Using 1,10-Phenanthroline-III. A Rapid Photochemical Method." Clays and Clay Mineralogy 36:379-381.

Last, G. V., B. N. Bjornstad, M. P. Bergeron, D. W. Wallace, D. R. Newcomer, J. A. Schramke, M. A. Chamness, C. S. Cline, S. P. Airhart, and J. S. Wilbur. 1989. Hydrogeology of the 200 Areas Low-Level Burial Grounds - An Interim Report. PNL-6820 Vol. 1, Pacific Northwest Laboratory, Richland, Washington.

Lindsey, K. A., B. N. Bjornstad, and M. P. Connelly. 1991. Geologic Setting of the 200 West Area: An Update. WHC-SD-EN-TI-008, Rev. 0, Westinghouse Hanford Company, Richland, Washington.

Lohman, S. W. 1972. Ground-Water Hydraulics, U.S. Geological Survey Professional Paper 708, Washington, D.C.

Machette, M. N. 1985. "Calcic Soils of the Southwestern United States." In Soils and Quarternary Geology of the Southwestern United States: Geological Society of America Special Paper 203, ed. D. L. Weide, p. 1-21.

Monger, H. C., L. A. Daugherty, W. C. Lindeman, and C. M. Liddell. 1991. "Microbial Precipitation of Pedogenic Calcite." Geology 19:997-1000. 
Neuman, S. P. 1975. "Analysis of Pumping Test Data from Anisotropic Unconfined Aquifers Considering Delayed Yield Gravity Response." Water Resources Research 11(2):329-342.

Palmer, C. D. 1993. "Borehole Dilution Tests in the Vicinity of an Extraction Well." Journal of Hydrology 146:245-266.

Peres, A. M., M. Onur, and A. C. Reynolds. 1989. "A New Analysis Procedure for Determining Aquifer Properties from Slug Test Data." Water Resources Research 25(7):1591-1602.

Rojstaczer, S., and D. C. Agnew. 1989. "The Influence of Formation Material Properties on the Response of Water Levels in Wells to Earth Tides and Atmospheric Loading." Journal of Geophysical Research 94(B9): 12,403-12,411.

Rojstaczer, S., and F. S. Riley. 1990. "Response of the Water Level in a Well to Earth Tides and Atmospheric Loading Under Unconfined Conditions." Water Resources Research 26(8):1803-1817.

Spane, F. A., Jr. 1993. Selected Hydraulic Test Analysis Techniques for Constant-Rate Discharge Tests. PNL-8539, Pacific Northwest Laboratory, Richland, Washington.

Spane, F. A., Jr. 1994. Applicability of Slug Interference Tests For Hydraulic Characterization of Unconfined Aquifers: (1) Analytical Assessment. PNL-SA-24283, Pacific Northwest Laboratory, Richland, Washington.

Spane, F. A., Jr., and S. K. Wurstner. 1993. DERIV: A Program for Calculating Pressure Derivatives for Hydrologic Test Data. PNL-SA-21569, Pacific Northwest Laboratory, Richland, Washington.

Stevens, T. O., H. D. Watts, J. J. Walker, and J. K. Fredrickson. 1992. "Optimization of Solid Growth Medium for Isolation and Culture of Microorganisms from the Terrestrial Subsurface." Abstract, American Microbiology 92nd General Meeting, Boston, Massachusetts, August 1992. p. 366.

Templeton, J. D., J. R. Nelson, and J. E. Amonette. 1994. "Improvements in the Quantitative Assay of Nonrefractory Minerals for Fe(II) and Total Fe Using 1,10-Phenanthroline." Program with Abstracts, 49th Northwest Regional Meeting of the American Chemical Society, Anchorage, Alaska.

U.S. Department of Energy (DOE). 1988. Consultation Draft Site Characterization Plan. DOE/RW0164, Vols. 1-9, Office of Civilian Radioactive Waste Management, U.S. Department of Energy, Washington D.C.

Weeks, E. P. 1979. "Barometric Fluctuations in Wells Tapping Deep Unconfined Aquifers." Water Resources Research 15(5):1167-1176. 


\section{Distribution}

No. of

Copies

OFFSITE

2 DOE/Office of Scientific and Technical Information

\section{ONSITE}

DOE Richland Operations Office

D. E. Trader, K8-50

Bechtel Hanford, Inc.

C. D. Kramer, H6-04 .

25 Pacific Northwest Laboratory

D. B. Anderson, P7-41

L. A. Doremus (3), K9-48
No. of

Copies

R. E. Engelman, K9-48

S. H. Hall, K6-96

S. P. Luttrell, K6-96

D. R. Newcomer (5), K6-96

F. A. Spane, K6-96

P. D. Thorne, K6-96

M. J. Truex (3), P7-41

V. R. Vermeul, K6-96

Publishing Coordination

Technical Report Files (5)

\section{Routing}

R. W. Bryce, K9-34

R. M. Ecker, SÉ-UI

M. J. Graham, K9-38

S. A. Rawson, K9-34

R. L. Skaggs, K9-34

P. C. Hays (last), K9-41

Distr. 1 